\title{
FOTOINTERPRETAÇÃO DE BACIAS HIDROGRÁFICAS E REDES DE DRENAGEM EM CINCO SOLOS DA REGIĀO DO RIO RIBEIRA DE IGUAPE NO ESTADO DE SÃO PAULO
}

CARLOS ALBERTO VETTORAZZI

Orientador: Prof. Dr. VALDEMAR ANTONIO DEMÉTRIO

Dissertação apresentada à Escola Superior de Agricultura "Luiz de Queiroz", da Universidade de São

Paulo, para obtenção do título de

Mestre em Irrigação e Drenagem.

PIRACICABA

Estado de São Paulo - Brasil

Junho - 1985 


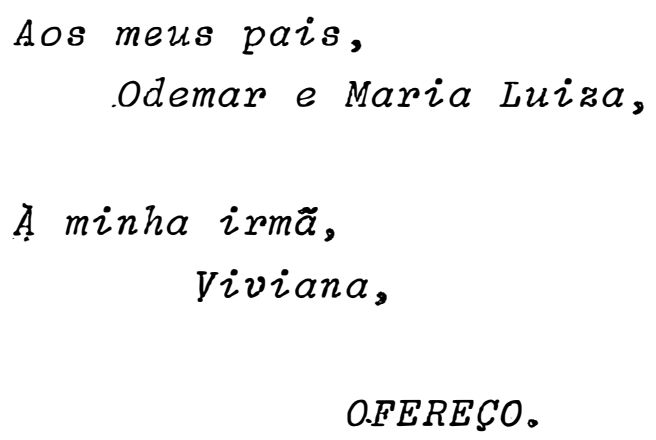


iii.

Ao Prof. Dr. Valdemar Antonio Demētrio; do Departamento de Engenharia Rural da Escola Superior de Agricultura "Luiz de Oueiroz", pela amizade e orientação segura na elaboração'deste trabalho. 
iv.

\section{AGRADEC IMENTOS}

Ao Departamento de Engenharia Rural da Escola Superior de Agricultura "Luiz de Queiroz", USP, atravēs de seu Che fe, Prof. Dr. Antonio Petta, por possibilitar a realização desta Dissertação.

Ao Curso de Pōs-Graduação em Irrigação e Drenagem, em nome de seu Coordenador, Prof. Dr. Décio E. Cruciani.

Ao Prof. Dr. Geraldo Victorino de França, do Departamento de Solos, Geologia e Fertilizantes da Escola Superior de Agricultura "Luiz de Queiroz", USP, pela inestimāvel colaboração.

Ao Dr. Igo F. Lepsch, da Seção de Pedologia do Instituto Agronōmico, Campinas, pela valiosa colaboração e emprés timo de material necessārio a confecção deste "traba1ho.

Ao Dr. Pedro L. Donzeli, Chefe da Seção de Fotointerpreta cão do Instituto Agronômico, Campinas, pelo empréstimo das fotografias aēreas utilizadas neste estudo.

Drạ Clarice G.B. Demētrio, do Departamento de Matemātị ca e Estatística da Escola Superior de Agricultura "Luiz de Queiroz", USP, pelas sugestões e valiosa colaboracão na anālise estatistica da presente pesquisa.

Ao Prof. Rubens Angulo Filho, pelo incentivo e sugestões na elaboração deste trabalho. 
Pàg.

RESUMO

$x \vee i$

SUMMARY

$x i x$

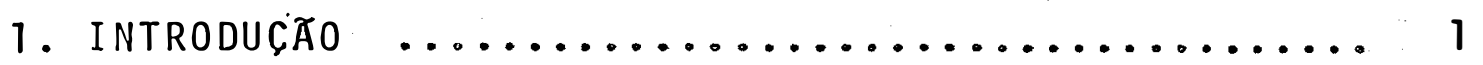

2. REVISÃO de literatura $\ldots \ldots \ldots \ldots \ldots \ldots \ldots \ldots \ldots$

2.1 - Fotointerpretação Aplicada aos Levantamentos de Solos ........................ 4

2.1 .1 -Generalidades $\ldots \ldots \ldots \ldots \ldots \ldots \ldots .4$

2.1 .2 - Mētodos de anālise fotogräfica .... 9

2.1 .3 - Vantagens e limitações .......... 13

2.2 - Características das Redes de Drenagem Relacionadas a Solos .................. 16

2.2.1 - Composição da rede de drenagem .... 16

2.2 .2 - Padrão de drenagem $\ldots \ldots \ldots \ldots \ldots \ldots 18$

2.2.2.1 - Características descritivas 20

2.2.2.2 - Características quantitati vas $\ldots \ldots \ldots \ldots \ldots \ldots \ldots \ldots \ldots$

3. MATERIAL E METOdOS $\ldots \ldots \ldots \ldots \ldots \ldots \ldots \ldots \ldots . \ldots . \ldots . \ldots$

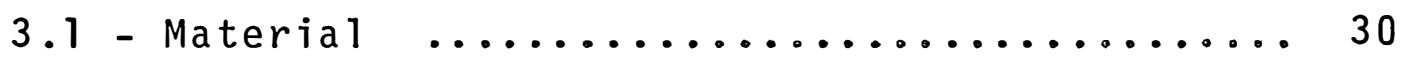

3.1 .1 - Caracterização do meio físico .... 30

3.1 .1 .1 - Localização geogrāfica .. 30

$3.1 .1 .2-$ clima $\ldots \ldots \ldots \ldots \ldots \ldots .32$ 
vi.

Pāg.

3.1 .1 .3 - Geologia $\ldots \ldots \ldots \ldots \ldots 35$

3.1 .1 .4 - Geomorfologia e relevo .. 41

3.1 .1 .5 - Vegetação primitiva e uso atual da terra ......... 43

3.1 .1 .6 - Hidrografia ......... 44

3.1 .1 .7 - Solos ............ 45

3.1 .2 - Material cartogrāfico .......... 57

3.1 .3 - Material fotogrāfico .......... 58

3.1 .4 - Equipamentos $\ldots \ldots \ldots \ldots \ldots \ldots \ldots . \ldots$

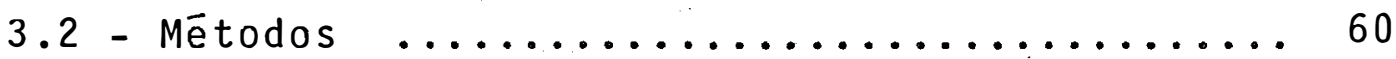

3.2.1 - Seleção da ārea de estudo ....... 60

3.2.2 - Elaboração dos mapas bāsicos de drenagem $\ldots \ldots \ldots \ldots \ldots \ldots \ldots \ldots 61$

3.2.3 - Seleção das bacias hidrogrāficas .. 64

3.2 .4 - Anālise das bacias hidrogrāficas .. 69

3.2.4.1 - Propriedades dimensionais 69

3.2.4.2 - Propriedades não dimensionais ................ 70

3.2.4.3 - Teste de semelhança geométrica .............. 71

3.2 .5 - Anālise das redes de drenagem .... 72

3.2.5.1 - Composição da rede de drenagem $\ldots \ldots \ldots \ldots \ldots$ 
vij.

Pāg.

3.2.5.2 - Características do padrão de drenagem ........... 74

3.2 .6 - Anālise estatistica ........... 77

3.2.6.7 - Teste de Kruskal-Wallis.. 77

3.2 .6 .2 - Comparações mūitiplas .. 80

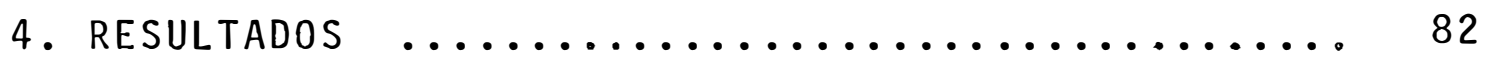

4.1 - Mapas Básicos de Drenagem ............. 82

4.2 - Seleção das Bacias Hidrogrāficas ........ 88

4.3 - Anālise das Bacias Hidrogrāficas ........ 94

4.3.1. - Propriedades dimensionais ...... 94

4.3 .2 - Propriedades não dimensionais ... 94

4.3 .3 - Teste de semelhança geomētrica ... 94

4.4 - Anālise das Redes de Drenagem .......... 101

4.4.1 - Composição da rede de drenagem ... 101

4.4.1.1 - Anāilise do nūmero de segmentos de rios ........ 101

4.4.1.2 - Anālise dos comprimentos dos segmentos de rios .. 101

4.4.2 - Características do padrão de drena-

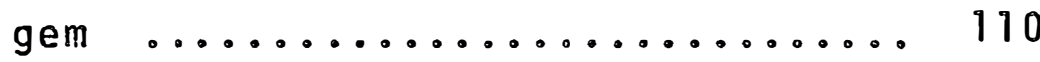

4.4.2.1 - Caracteristicas descriti-

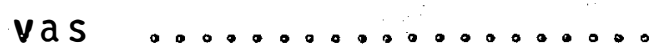


viii。

Pāg .

4.4.2.2 - Caracteristicas quantitativas ................ 110

5. DISCUSSÃO DOS RESULTADOS ................. 115

5.1 - Mapas Bāsicos de Drenagem ............ 115

5.2 - Selecão das Bacias Hidrogrā́ficas e Teste de

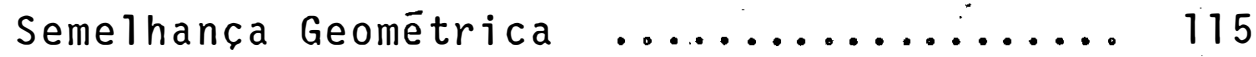

5.3 - Anāilise das Bacias Hidrogrāficas ........ 117

5.3.1 - Propriedades dimensionais ...... 117

5.3.2 - Propriedades não dimensionais ... 119

5.4 - Anāilise das Redes de Drenagem ......... 119

5.4.1 - Composicão da rede de drenagem ... 119

5.4.1.1 - Anālise do nūmero de segmentos de rios ....... 119

5.4.1.2 - Anāije do comprimento dos segmentos de rios ...... 121

5.4.2 - Características do padrão de drena-

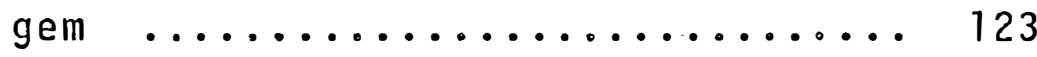

5.4.2.1 - Caracteristicas descritivas ................. 123

5.4 .2 .2 - Caracteristicas quantitativas .................. 124 
ix.

Pàg.

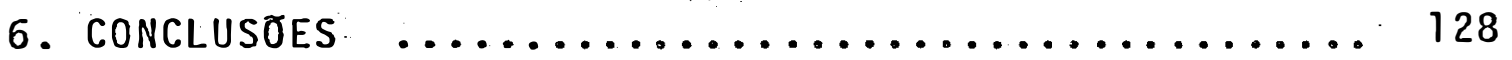

7. Literatura CitAda. .................. 131

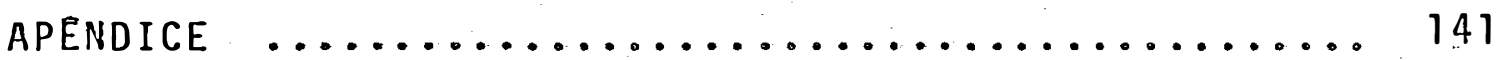




\section{LISTA DE TABELAS}

TABELA

Pāg。

1 Classificação da textura topogrāfica, para perimetro expresso em milhas e em quilómetros

2 Valores médios dos principais indices de dre nagem, para vārios solos, utilizando bacias hidrográficas como unidades amostrais ....

3 Médias mensais de temperatura, precipitação pluvial e de resultados do balanco hidrico, segundo "Thornthwaite e Mather - 1955 (125 mm), para o municīpio de Pariqüera-Açu - SP

4 Coluna estratigráfica do vale do Ribeira e li toral sul do Estado de São Paulo ......... 40

5 Médias, seguidas dos respectivos erros padrões, de resultados de anālise de amostras de solo de dois horizontes de cinco solos re conhecidos e cartografados na folha topográfica (INSTITUTO BRASILEIRO DE GEOGRAFIA E ES TATISTICA, 1974), de Pariqüera-Açu ....... 50

6 Principais caracteristicas morfológicas determinadas em perfil representativo da unida de Pariqüera $\ldots \ldots \ldots \ldots \ldots \ldots \ldots \ldots . . . \ldots \ldots$ 
$x i$

TABELA

Pāg.

7 Principais caracterīsticas morfolōgicas determinadas em perfil representativo da unida de Táquaruçu

52

8 Principais características morfológicas determinadas em perfil representativo da unida

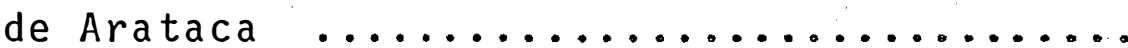

9 Principais características morfológicas determinadas em pérfil representativo da unida de Vapamirim

10 Principais caracterīsticas morfológicas determinadas em perfil representativo da unida de Canfilito

11 Principais caracteristicas morfológicas e fun cionais das unidades de mapeamento em estudo

12 Propriedades dimensionais das bacias hidrogrāficas estudadas; médias e respectivos erros padrõe

13 Resultados do teste de Kruskal-Wallis e das Comparacões Mūitiplas aplicados às proprieda des dimensionais das bacias hidrogrāficas em estudo 
TABELA

Pāg.

14 Propriedades não dimensionais das bacias hidrogrāficas representativas das unidades de

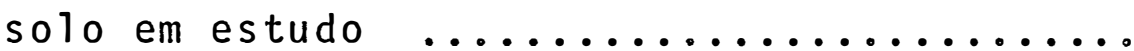

15 Anālise dimensional e teste de semelhança geo métrica aplicados às bacias hidrogrāficas se

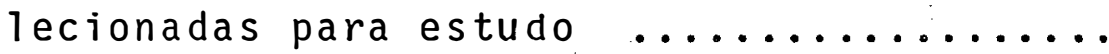

16 Número de segmentos de rios observados em ca da ordem de ramificação e o total para as ba cias nidrogräficas; médias e respectivos erros padrões ...................... 102

17 Resultados do teste de Kruskal-Wallis e das Comparações Mūitiplas aplicados ao parâmetro

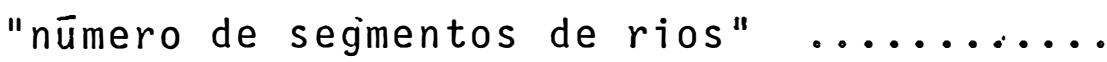

18 Comprimentos totais de segmentos de rios em cada ordem de ramificação; médias e respecti vos erros padrões

19 Resultados do teste de Kruskal-Wallis e das Comparações Mūltiplas aplicados ao parâmetro "comprimentos totais de segmentos de rios em cada ordem de ramificação" ............ 106

20 Comprimento médio de segmentos de rios em ca da ordem de ramificação; médias e respecti-

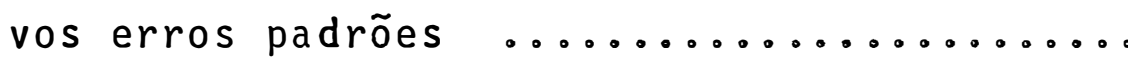


$x i i j$

TABELA

Pàg。

21 Resultados do teste de Kruskal-Wallis e das Comparações Múltiplas aplicados ao parâmetro "comprimento médio de segmentos de rios em ca da ordem de ramificacão"

22 Caracteristicas descritivas do padrão de dre nagem das unidades de solo estudadas .....

23 Caracteristicas quantitativas dos padrões de drenagem e as classes de textura topográfica das bacias hidrográficas representativas das unidades de solo em estudo ............ 112

24 Resultados do teste de Kruskal-Wallis e das Comparacões Mūltiplas aplicados aos dados re ferentes às características quantitativas do padrão de drenagem ...................113 
xiv.

\section{LISTA DE FIGURAS}

F I GURA

Pāg.

1 Região do rio Ribeira de Iguape no Estado de São Pau1o, com destaque para a ārea de estudo

2 Balanço hỉdrico pelo mētodo de "Thornthwaite e Mather - 1955" (125 mm), para o município de Pariqüera-Acu $\ldots \ldots \ldots \ldots \ldots \ldots . . . \ldots$

3 Mapa geolōgico da ārea de estudo (folha de Pariqüera-Acu)

4 Mapa de solos da ārea de estudo (folna de Pa riqüera-Acu)

5 Esquema da distribuicão das diferentes unida des de solo em estudo, em função do relevo e

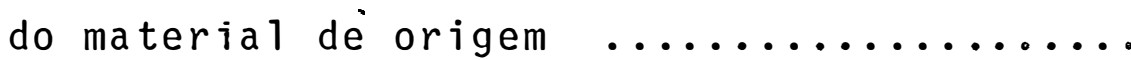

6 Ārea ūtil em uma fotografia aérea vertica 1..

63

7 Mapa bāsico de drenagem e posicões ocupadas pelas bacias hidrogrāficas selecionadas, representativas da unidade Pariqüera (LAa) ...

8 Mapa bāsico de drenagem e posições ocupadas pelas bacias hidrogrāficas selecionadas, representativas da unidade Taquarucu (PVLa-1) 
9 Mapa básico de drenagem. e posições ocupadas pelas bacias hidrogräficas selecionadas, representativas da unidade Arataca (PVLa-2) ..

10 Mapa básico de drenagem e posições ocupadas pelas bacias hidrográficas selecionadas, representativas da unidade Vapamirim (PVa) $\quad$. 86

11 Mapa básico de drenagem e posições ocupadas pelas bacias hidrográficas selecionadas, representativas da unidade Canfilito (Ca-2) ..

12 Bacias hidrogräficas representativas da unidade Pariqüera (LAa). Escala aproximada 1:25.000

13 Bacias hidrogräficas representativas da unidade Taquaruçu (PVLa-1).Escala aproximada 1:25.000

14 Bacias hidrogräficas representativas da unidade Arataca (PVLa-2). Escala aproximada 1:25.000

15 Bacias hidrogrāficas representativas da unidade Vapamirim (PVa). Escala aproximada 1:25.000

16 Bacias hidrográficas representativas da unidade Canfilito $(\mathrm{Ca}-2)$. Escala aproximada 1:25.000 
FOTOINTERPRETAÇAO DE BACIAS HIDROGRAFICAS E REDES DE DRENAGEM EM CINCO SOLOS DA REGIAO DO RIO RIBEIRA DE IGUAPE NO ESTADO DE SAO PAULO

Candidato: Carlos Alberto Vettorazzi

Orientador: Prof. Dr. Valdemar Antonio Demétrio

Com base na interpretação de fotografias aẹ reas verticais na escala 1:25.000, fez-se a caracterizaça fisiogrāfica de cinco unidades de solo, ocorrentes na região do rio Ribeira de Iguape no Estado de São Paulo, atra vēs de elementos relacionados ao padrão de drenagem superficial e tambēm testou-se a eficiência de vārios indices fó tointerpretativos na discriminaça dessas unidades de solo.

A ārea estudada localiza-se na porção sul do litoral do Estado de São Paulo, apresentando um regime climático do tipo Cfa, denominado "mesotérmico ümido sem es tiagem" 。

Os cinco solos estudados foram: a) Latosso10 Amarelo-LAa ālico (unidade Pariqüera); b) Podzólico Ver 
melho-Amarelo Latossōlico ālico - PVLa-l (unidade Taquarucu); c) Podzólico Vermelho-Amarelo Latossólico ālico-PVLa -2 (unidade Arataca); d) Podzólico Vermelho-Amarelo àlico - PVa (unidade Vapamirim); e) Cambissolo álico - Ca-2 (uni dade Canfilito). Cada unidade foi representada por três ba cias hidrogräficas de terceira ordem de ramificação.

0 estudo do padrão de drenagem, conduzido principalmente pelo "método de anālise dos elementos", per mitiu as seguintes conclusões:

- a anālise das propriedades dimensionais das bacias hidrogräficas acusou diferenças entre os solos estu dados, à exceção das unidades Arataca e Canfilito que apresentaram valores médios, para os parâmetros analisados, muito próximos entre si;

- as propriedades não dimensionais das bacias hidrogrāficas não foram eficientes na distinção entre as unidades de solo estudadas, pois mostraram uma hete rogeneidade generalizada quanto à forma das bacias e uma tendência à assimetria das vertentes;

- a anālise dos elementos ligados à composicão das re des de drenagem, no geral mostrou valores contrastantes para as unidades Pariqüera e Vapamirim, com valores intermediārios para as unidades Taquaruçu, 
xviji.

Arataca e Canfilito;

- alguma diferenciação entre as unidades de solo, com respeito às características descritivas do padrão de drenagem, foi observada no grau de integração,na densidade, nos ângulos de junção e no tipo ou mode10 do padrão;

- o indice freqüencia de rios, seguido da densidade de drenagem, foi altamente eficiente na distincão entre todas as cinco unidades de solo estudadas;

- os valores de densidade de drenagem refletiram bem a resistência dos solos à erosão. 
$x i x$

\section{PHOTOINTERPRETATION OF WATERSHEDS AND DRAINAGE \\ NETWORKS IN FIVE SOILS FROM THE RIBEIRA DE \\ IGUAPE RIVER REGION IN THE SAOO PAULO STATE}

Candidate: Carlos Alberto Vettorazzi

Adviser: $\quad$ Prof. Dr. Valdemar Antonio Demëtrio

Based on the interpretation of vertical aerial photographs (scale $1: 25,000$ ), the physiographic characterization was made of five soil units, occurring in the Ribeira de Iguape River region in the São Paulo State, through the elements related to the superficial drainage pattern and the efficiency of the studied photointerpretative indexes on the discrimination between these soilunits was tested.

The studied area is located in the south portion of the São Paulo State coast, with a climate of the Cfa type, identified as "humid mesothermic with no drought".

The five soils studied were: a) Alic Yellow Latosol - LAa (Pariquera unit); b) Alic Latosolic Red-Yel- 
low Podzolic - PVLa-1 (Taquarucu unit); c) Alic Latosolic Red-Yellow Podzolic - PVLa-2 (Arataca unit); d) Alic Red-Yellow Podzolic - PVa (Vapamirim unit); e) Alic Cambisol - Ca-2 (Canfilito unit). Each unit was represented by three third-order watersheds.

The study of the drainage pattern was made mainly by the "elements analysis method", and led to the following conclusions:

- the analysis of dimensional properties of the watersheds showed differences between the studied soils, except for the Arataca and Canfilito units, which showed very similar medium values, for the analysed parameters;

- the non dimensional properties of the watersheds were not efficient in distinguishing the studied soil units, showing a generalized heterogeneity related to the watersheds' shape and a tendency to slope assymetry;

- the analysis of elements related to the drainage networks composition, in general showed contrasting results for the Pariquera and Vapamirim units, with intermediate values for the Taquarucu, Arataca and Canfilito units; 
$x \times i$

- some differentiation between the soil units, with respect to the descriptive characteristics of .. the drainage patterns, was observed in the integration degree, density, junction angles and model or pattern type;

- river freqüency index, followed by drainage density, was highly efficient in differentiating all the five studied soil units;

- drainage density values reflected the erosion resis tance of the soils. 


\section{INTRODUÇAOO}

A necessidade imperiosa de atender a crescente demanda de alimentos e matéria-prima de origem agrícola, conduz à busca da otimização no uso de nosso principal recurso natural, que è o solo. Essa otimização implica na manutenção, pelo prazo mais longo possîvel, da capacida de produtiva do solo, sem que ocorra a sua degradação.

0 inventário dos solos de uma determinada ārea ē o primeiro passo no estudo de uma solução ótima (ou, pelo menos, o mais próximo possîvel da ótima) para sua utí lização agrīcola. Nesse inventārio devem constar o mapeamen to e o maior número possivel de informações sobre as unidades de solo. A esse trabalho dá-se o nome de "Levantamen to de Solos". 
0 emprego de fotografias aēreas, em levantamentos de solos, tem demonstrado sua utilidade, seja pe1 a reducão de tempo, custo e esforco de trabalho, seja peIa maior precisão no traçado de limites entre unidades de solo ou, ainda, pela quantidade de informacões que fornecem.

Vários são os elementos que podem ser obser vados nas imagens fotogräficas que se correlacionam com os solos sobre os quais se encontram; entre eles, a rede de drenagem é um dos que apresentam relativamente fácil inter pretação, alem de ser um dos mais eficientes na distinção entre unidades de solo.

Para a fotointerpretação, a rede de drenagem é o conjunto de canais naturais (ou cursos d'água), tem porários ou permanentes, que efetuam o escoamento superficial das àguas de uma determinada ārea.

Com base na hipōtese de que solos semelhan tes aparecem nas fotografias aēreas com padrões semelhantes e solos diferentes aparecem com padrões diferentes (FROST, 1960), este trabalho tem por finalidades:

- fazer a caracterização fisiográfica de cinco unidades de solo, ocorrentes na região do rio Ribeira de Iguape no Estado de São Paulo, através de elementos relacionados ao padrão de drenagem superficial; 
- testar a eficiência de vārios indices fotointerpretativos, na discriminação das diversas unidades de solo estudadas. 


\section{REVISAOO DE LITERATURA}

2.1 - Fotointerpretação Aplicada aos Levantamentos de Solos

\subsection{1 - Generalidades}

'0 emprego das técnicas de fotointerpretação em estudos pedológicos apresenta reconhecida utilidade, principalmente naqueles que visam a identificacão e mapeamento de unidadeś, ou seja, nos levantarientos de solos.

Existem vārios tipos de levantamentos de so los, entre os quais os mais conhecidos são os pedológicos, os morfopedológicos e os utilitários.

Nos levantamentos pedológicos os solos são caracterizados, ordenados e cartografados segundo sistema de classificacão baseado em critérios genético-morfológi- 
cos. São efetuados pelo pedólogo que, para isso, examina os solios no campo, determina seus limites geográficos e de limita-os em um mapa base, topogrāfico ou fotografia aérea. Depois de concluído, o levantamento pedológico constará de um mapa e de um texto explicativo, ou boletim. Nesse tipo de levantamento, o emprego de fotografias aéreas, através de fotointerpretação, é ūtil, mas a separação das unidades depende de um bom estudo da correlação solo-paisagem.

Segundo LEPSCH (1985), a utilização maior das fotografias aéreas está no levantamento morfopedológico, ou fisiopedológico, ainda pouco comum no Brasil, que se baseia na individualização de unidades de mapeamento que são aparentes no decurso da fotointerpretação. A unida de primāria de mapeamento morfopedológico è definida como "uma ārea com padrão definido de topografia, solo e vegeta cão" (CHRISTIAN e STEWART, 1968), ou "uma ārea com padrão definido de fisionomias terrenas que estão geneticamente relacionadas" (BRINK et alii, 1966). Os levantamentos morfopedolögicos têm sido largamente utilizados em paîses de lingua oficial inglesa da África, e também na Austrằita, onde denominam-se "land system". As fotografias aéreas são utilizadas diretamente no mapeamento das unidades, deixando-se a identificação do(s) solo(s) predominante(s) em cada unidade para o final, em trabalho de campo. 
0 levantamento utilitārio diz respeito mais ao inventārio de dados essenciais relativos às características e propriedades da terra relevantes para interpretacõ̃es necessárias à classificação em classes de capacidade de uso e outras, ūteis ao planejamento das präticas de conn servação do solo.

Neste trabalho estuda-se a aplicação de fotointerpretação em levantamentos do tipo pedológico.

'As fotografias aéreas foram utilizadas em levantamentos de solos, primeiramente como um mapa básico, oferecendo maior facilidade de orientação no campo e, con-

sequentemente, aumentando o rendimento de trabalho. 0 primeiro mapeamento de solos utilizando fotografias aérea foi realizado nos Estados Unidos, em 1929, por Bushnell e colla boradores, conforme relatam SIMONSON (1950.) e ROURKE e AUS TIN (1951). Ćcom o tempo, tēcnicos e cientistas percebe ram que, dada a riqueza de detalhes registrados nas fotografias aéreas, elas podiam ser também interpretadas, ou seja, utilizadas como uma fonte adicional de informacões, em relação aos solos. Modernamente, além dessas duas util $\underline{i}$ zações (mapa bāsico e fonte de informações), as fotografias aēreas são utilizadas tambēm como uma nova forma de apresentação dos mapas de solos, isto é, as unidades de mapea- 
mento são delimitadas diretamente sobre mosaicos fotográfi $\cos$.

Segundo VALERIO FILHO et alii (1981), embora desde o final da Segunda Guerra Mundial os pedólogos ve nham utilizando mais intensivamente fotografias aéreas em seus trabalhos, não houve, inicialmente, a preocupação em descrever as metodologias da técnica que surgia. Somente a partir de aproximadamente duas décadas é que começaram a aparecer, entre nós, citações e metodologias de trabalho para o uso de fotografias aēreas em pedologia, vindo a se constituir no que se convencionou denominar fotopedologia. COLWEL (1952) define fotointerpretação como o ato de se examinarem imagens fotográficas de objetos,com o propōsito de identificā-los e avaliar o seu significado' Num sentido mais amplo, SUMMERSON (1954) define interpreta cão como a previsão do que não pode ser realmente visto. Esta ūltima definição, tendo em vista o solo como um compo nente da paisagem, resultante da ação ativa do clima e organismos sobre o material de origem situado num determinado relevo durante certo perīodo de tempo, ajusta-se perfei tamente à interpretaça fotogrāfica de solos, uma vez que as fotografias aéreas não mostram todo o corpo do solo, mas somente sua superfície e, ainda, geralmente recoberta por vegetação. Porém, vārios aspectos visíveis na superfí- 
cie do terreno, como as formas topogräficas, os padrões de drenagem, de erosão, de vegetação e de uso do solo, mais a tonalidade fotogräfica, indicam ou sugerem diferenças entre solos, bem como seu padrão de distribuicão. Para se ajustar tais definições à fotointerpretação pedológica, hă que se buscar, a priori, de acordo com ROURKE e AUSTIN (1951), LUEDER (1959), BURINGH (1960) e FROST (1960), o es tabelecimento de correlações entre a natureza do perfil de solo e seus aspectos externos evidenciados pela fotografia aèrea.

SMITH e AANDAHL (1957) afirmam que as relacões entre solos e seus ambientes de ocorrēncia variam em detalhes de uma.região para outra; porém, as relações geralmente existem e um pedólogo familiarizado com os solos de uma região, observarido a paisagem, pode predizer onde estão os limites entre solos ou, examinando um mapa de so-. 1os, visualizar a paisagem. Segundo ROURKE e AUSTIN(1951), um pedólogo com experiência em determinada região, pode fa zer certas estimativas a respeito dos aspectos internos do solo, por meio de fotografias aéreas, porēm não pode trans ferir seus critérios interpretativos de uma região para ou tra, porque muitos dos indícios que ele usa têm diferente significação em regiões distintas. LUEDER (1959) adverte que a interpretação do significado de um padrão de drena- 
gem, por exemplo, não é fācil, exigindo alēm da apreciação teórica, a experiência no processo de correlacionar detaThes do terreno com sua imagem fotográfica.

'A fotointerpretação utiliza. o princīpio de "convergência de evidências", apresentado por COLWELL(1952), que estabeleceu existirem vários indícios sobre a identida de de um objeto desconhecido e, se a maioria deles apontar para uma mesma hipōtese, esta serā provavelmente a correta!

"0 fundamento do método fotointerpretativo assenta-se, segundo FROST (1960), sobre três princīpios bá. sicos: 1) solos semelhantes aparecem nas fotografias aéreas com padrões semelhantes; 2) solos diferentes aparecem com padrões diferentes; e 3) correlações de características da imagem fotográfica com as propriedades do solo, observadas no campo e no laboratōrio, podem ser inferidas por meio de fotointerpretaçã '

2.1.2 - Métodos de anālise fotogrāfica Referindo-se à fotointerpretação aplicada a levantamentos de solos, GOOSEN (1967) descreve três métodos principais de anāilise:

a) Método de anālise dos padrões: próposto por FROST (1960), esse método considera como padrões indicativos das 
condicões do terreno, a forma fisiográfica, a drenagem, os aspectos de erosão, a vegetação natural, a tonalidade foto grāfica e o uso agrícola. Fixadas as condicões ambientais, as grandes unidades da paisagem são subdivididas e estudados seus padrões locais, estabelecendo-se correlacões com as condicões do terreno.

b) Método de anāitise fisiogräfica: requer amplo conhe cimento dos processos geomorfogenéticos (intemperização, erosão, sedimentacão, etc.), bem como sua influência na pai sagem e, consequentemente, na imagem fotogrāfica. Classifí ca o terreno em unidades fisiogräficas. Sugerido por BURINGH (1960) e desenvolvido por GOOSEN (1967), este método exige bons conhecimentos em geomorfologia. E tido por diversos autores como o método mais eficiente na caracterização. de solos, através de fotointerpretacão.

c) Método de anālise dos elementos: comparado com os demais métodos, tem a vantagem de poder ser utilizado por pedólogos com pouca experiência em fotointerpretação. Utiliza-se do princĩpio de "convergência de evidências" (COLWELL, 1952) para a separação das unidades de solo, através da anālise sistemática dos elementos da paisagem, relacionando as características da superfície às condições do, so10. O método de anālise dos elementos foi desenvolvido por BURINGH (1960). 
Essa separação em três mētodos distintos de fotointerpretação è meramente artificial, segundo GOOSEN (1967), podendo haver, em certos casos, a combinação de dois ou até dos três métodos.

$\mathrm{Na}$ maior parte dos trabalhos de fotointerpretação aplicada a solos, segundo SILVA (1977) e MANECHINI (1981), foi utilizado o método de análise dos elementos, para o estudo de indices de drenagem em bacias hidrogräficas e amostras circulares.

A forma fisiográfica é considerada, por alguns autores, como o elemento mais importante na fotopedologia. Esse elemento, entretanto, é apenas um dos componen tes do padrão de solos e a interpretaça de outros elementos, tais como as características de drenagem ou de erosão, podem, de acordo com FRANCA (1968), fornecer informações igualmente importantes.

LUEDER (1959) sugere que, depois da forma fisiogräfica, a drenagem superficial é, provavelmente, o mais seguro indicador das condicões do terreno. Faz-se necessārio, entretanto, um bom nível de conhecimento em pedo logia e experiência adequada em fotointerpretação. Segundo esse autor, o padrão de drenagem em uma ārea è, em grande parte, função da relação infiltração/deflūvio que, por' sua ves, relaciona-se intimamente com as características do so. 
10 , embora o clima, o relevo e a cobertura vegetal da região tambēm exerçam influência.

Para FROST (1960), é importante que se estü dem os aspectos regionais antes dos detalhes, para que se possam relacionā-los a fatores ambientais como fisiografia, geologia e clima.

Segundo RABBEN (1960), o trabalho de fotointerpretacão consiste de duas etapas principais: na primeira são feitas observações, identificacões, coleta de da dos e medições nas imagens fotográficas; e, na segunda,são tiradas conclusões, atravēs da inducão ou deducão de fenômenos, aplicando-se as informações obtidas na soluça de problemas especificos.

Com referência à metodologia, RABBEN (1960) considera mais produtiva, sob os aspectos de tempo e esfor co dispendidos, a utilização da técnica denominada "pesqui sa lógica", pela qual, baseado em probabilidades, o fotointērprete pesquisa detalhadamente apenas as āreas onde possam ser encontrados os objetos de interesse ao estudo, ao invēs de examinar minuciosamente grandes àreas, em busca desses objetos. 


\section{2.i.3 - Vantagens e limitações}

'Vārias são as vantagens da utilização de fó tografias aēreas em levantamentos de solos. GOOSEN (1967) afirma que a visão panorâmica que as fotografias aéreas pro porcionam, como um meio de documentacão e pesquisa dos fenômenos da paisagem, não tem rival a um custo comparāvel. Admite ainda que, embora o trabalho de campo não seja subs tituỉdo completamente pelo uso de fotografias aéreas,o ren dimento e a exatidão dos trabalhos são altamente favorecidos.

"Para AMARAL e AUDI (1972), a fotografia aérea apresenta-se como material de trabalho indispensável nos levantamentos de solos, oferecendo ganho de tempo, pre cisão de limites e visão global da paisagem com riqueza de detalhes'.

Segundo RABBEN (1960), três fatos fundamen tais justificam a utilizada incomparāvel da fotografia aérea na caracterização da superfície terrestre: (a) na esca 1a de 1:20.000 cada fotografia aérea cobre uma áreade apro ximadamente $20 \mathrm{~km}^{2}$, e na escala de $1: 25.000$, cerca de $33 \mathrm{~km}^{2}$; (b) os pares estereoscōpicos de fotografias aéreas proporcionam imagens tridimensionais da superficie terrestre e dos objetos localizados sobre ela; e (c) as imagens foto- 
grāficas são representações permanentes dos objetos originais, permitindo ao fotointérprete um exame cuidadoso e de talhado da ārea, no momento em que ele desejar, em condicões de trabalho mais cōmodas e favoráveis do que aquelas normalmente conseguidas no campo!

Quanto às limitações da fotointerpretacão aplicada a solos, podemos considerar três grupos de fatores, citados por FROST (1960): material fotogräfico e aspectos técnicos; habilidade do fotointérprete; e características intrínsecas da paisagem.

DUNBAR (1959) adverte sobre solos de ocorrência em regiões tropicaịs e, referindo-se particularmente a alguns solos do Brasil, cita o caso de Latossolos com alto conteúdo de argila que, nas imagens fotogrāficas, tēm a aparência de areia barrenta: porosidade relativamente ele vada, ângulo de repouso moderadamente ingreme e padrão de drenagem esparso, pouco integrado.

GOOSEN (1967) observa que as diferenças entre tipos, fases e sēries de solo, não são sempre visíveis na superficie terrestre. Este fato permite deduzir que, em levantamentos detalhados a fotointerpretaça a apresenta valor limitado, o que pode ser verificado pelos critérios e definicões de levantamentos, desde os esquemáticos até os 
detalhados. De um modo geral, a maioria dos autores, dentre os quais incluem-se CRESWICK e ROCKWELL (1953), BOMBERGER e DILL (1960), BURINGH (1960) e GOOSEN (1967), concordam que a fotointerpretação é mais útil em levantamentos de reconhecimento do que em levantamentos detalhados.

'A respeito da sensibilidade da imagem fotogrāfica para o registro dos detalhes do terreno, AB'SABER (1960) salienta que esta propriedade depende muito das con dições de clima da região onde foi realizada a cobertura aerofotogrāfica. Nas regiões de clima seco o nūmero de informações conseguidas atravēs de exame de fotografias aēreas é muito maior que o das regiões de clima ümido.' 
2.2 - Caracteristicas das Redes de Drenagem Relacionadas a Solos

\subsection{1 - Composição da rede de drenagem}

Deve-se a HORTON (1945) a expressão "composição da rede de drenagem" para indicar o número e o comprimento de rios nas diferentes ordens de ramificacão. Assim, a composição de uma rede de drenagem obedece a certos conjuntos de "leis". A idéia de hierarquia fluvial permite uma anālise das bacias hidrogrāficas através do comportamento das caracteristicas dos rios numa ou em diferentes bacias (SUGUIO e BIGARELLA, 1979). O conceito de nūmero de ordem foi estabelecido para definir a hierarquizaça fluvial.

HORTON (1945) classificou como de primeira ordem os elementos das cabeceiras de drenagem, não ramificados, ficando a ordem mais elevada para o rio principal. STRAHLER (1952) modificou o sistema de HORTON (1945), classificando segmentos de rios, de modo que toda nascente è um segmento de primeira ordem; quando dois segmentos de primeira ordem se juntam, formam um de segunda ordem; quando dois de segunda ordem se juntam, formam um de terceira e assim por diante. 
A padronização na notação trouxe vantagens e facilidades na anālise e comparacão das redes de drenagem, uma vez que em fotopedologia somente são comparáveis entre si, bacias hidrogräficas de mesma ordem.

o estudo de HORTON (1945) baseou-se nas observacões de Playfair, a respeito da correspondēncia dos rios e seus respectivos vales, evidenciando a importância da relação infiltração/deflúvio na composição do sistema de drenagem superficial. As variações nessa relação condicionam uma maior ou menor intensidade de erosão pelas äguas correntes, influindo no grau de desenvolvimento da rede de drenagem. LUEDER (1959) confirmou tais conclusões, atribuin do as formas do padrão de drenagem superficial à relacão infiltração/deflūvio e às características dos materiais ocor rentes na ārea considerada. Materiais relativamente impermeáveis, como argila e argilitos, condicionam a formaça de redes mais densas, quando comparadas às formadas sobre materiais mais permeáveis, como arenito e cascalhos. 0 autor adverte, porēm, sobre a existência de exceções, que FRANÇA (1968) atribuiu às diferentes condições de solos que podem, às vezes, ocorrer em àreas similares quanto a material de origem e modos de deposição. 
Para SUGUIO e BIGARELLA (1979), a drenagem de uma região depende não só da pluviosidade e topografia, como também da cobertura vegetal, do tipo de solo, da litologia e estrutura das rochas.

HORTON (1945) considera a resistēncia do so 10 à erosão e sua capacidade de infiltração como sendo dois fatores muito importantes, alēm do relevo e precipitação, no processo de erosão hỉdrica. Assim sendo, considerando-se um longo perīodo de tempo, em qualquer ārea sujeita a esse processo de erosão, acabará por prevalecer a resistência do solo e da rocha subjacente.

FREIRE e PESSOTTI (1974), estudando a erodi bilidade dos solos do Estado de São Paulo, verificaram serem os Latossolos mais resistentes à erosão hîdrica acelerada, quando comparados a solos Podzólicos e, entre estes, a erodibilidade aumenta proporcionalmente a gradiente tex tural entre os horizontes $A$ e $B$.

\subsection{2 - Padrão de drenagem}

A drenagem fluvial é constituída por um con junto de canais de escoamento interligados, formando a bacia de drenagem, ou bacia hidrográfica. Esta é definida co mo a ārea drenada por um rio, ou por um sistema fluvial com 
posto por um curso principal e seus tributários. As bacias hidrogrāficas exibem vārias peculiaridades conhecidas como padrões de drenagem. Estes dizem respeito à situação espacial dos rios, a qual é, em grande parte, controlada pela estrutura geológica do terreno (SUGUIO e BIGARELLA, 1979).

0 padrão de drenagem $\bar{e}$ influenciado pela pró fundidade do substrato rochoso e pelas declividades das su perficies. De maneira geral, com a diminuição da profundidade do substrato rochoso e com o aumento das declividades, ocorre aumento no número de rios e diminuição em seus comprimentos médios, além de alterar a distribuição desses rios, segundo SOUZA (1975), CARVALHO (1977) e FREIRE(1977).

0 padrão de drenagem expressa o comportamen to hidrológico do solo ao qual está associado e pode, portanto, variar em função da ação conjunta ou isolada dos fa tores morfogenéticos e agentes modificadores externos.

No trabalho de FRANÇA (1968), as variações verificadas no padrão de drenagem foram atribuỉdas, em prí meiro lugar, à natureza do solo e, depois, à posição topogrāfica e à natureza e profundidade do substrato rochoso. Esses fatores foram tambëm verificados por DEMETRIO (1977), condicionando o padrão de drenagem.

SILVA (1977) atribuiu ao relevo, em primeiro lugar e ao controle geológico em seguida, o grau de 
desenvolvimento das redes de drenagem, atravēs da alteração da relação infiltração/deflūvio.

Para ANGULO FILHO (1981), as caracteristicas do padrão de drenagem foram condicionadas pela natureza e propriedades dos solos estudados, pela natureza e pro fundidade do substrato rochoso, posição que ocupam no rele. vo regional e, tambēm, pela vegetação e uso da terra.

0 padrão de drenagem pode ser caracterizado de duas maneiras: qualitativamente, atravēs da descrição de seus atributos; e quantitativamente, pela medição e expres são numérica dos mesmos.

\subsubsection{1 - Caracteristicas descritivas}

Segundo LUEDER (1959), o objetivo principal da anālise da drenagem superficial ê fornecer indicacões so bre a relação infiltração/deflūvio, capacidade de infiltra ção, erodibilidade e textura dos materiais presentes emuma área. Para indicar os aspectos significativos do padrão de drenagem, LUEDER (1959) propōs a descrição das seguintes caracteristicas: grau de integração, densidade, grau de uniformidade, orientação, grau de controle, āngulos de junção e angularidade. A característica "tipo ou modelo"do padrão foi sugerida por PARVIS (1950). RICCI e PETRI (1965) 
introduziram o termo "anomalias" para auxiliar na caracterização do padrão de drenagem, aplicável às características de um ou mais rios que não se adaptam àquelas prevalecentes ou dominantes apresentadas por todos os outros rios da ārea. 0 Ṫtem "anomalias" fora sugerido, anteriormente, por MILLER e MILLER (1961).

\subsubsection{2 - Caracteristicas quantitativas}

Segundo HORTON (1945), a determinação de in dices quantitativos da rede de drenagem possibilita inferēncias sobre diversas condicões do terreno, eliminando a in da a subjetividade da caracterização descritiva.

SILVA (1977) relata que diversos trabalhos. de pesquisa com bacias hidrogräficas, estudando o padrão de drenagem, resultaram em dados significativos para a dis tinção entre solos de naturezas diferentes.

HORTON (1945), em sua tentativa de quantif $\underline{\mathbf{j}}$ car o grau de desenvolvimento da drenagem superficial de bacias hidrográficas, apresentou duas relações envolvendo o comprimento e número de rios: densidade de drenageme fre qüència de rios.

A densidade de drenagem expressa a relação entre precipitação pluviométrica e capacidade de infiltra- 
çao do solo e é quantificada através da equação:

$$
D d=\frac{L t}{A}
$$

sendo Lt o comprimento total dos rios das diversas ordens e A a ārea da bacia hidrogrāfica.

STRAHLER (1957) considerou a densidade de drenagem como sendo o parâmetro mais importante na anālise das formas de terreno. HORTON.(1945), contudo, concluiu que o padrão de drenagem e a densidade, separados ou combinados, não são suficientes para a perfeita caracterização da. rede de drenagem. NOGUEIRA (1979), estudando características quantitativas do padrão de drenagem, concluiu sera den sidade o parâmetro mais eficiente para evidenciar diferen-. cas entre unidades de solo.

CHRISTOFOLETTI (1969) cita que, como a densidade de drenagem correlaciona o comprimento total dos ca nais ou rios com a ārea da bacia hidrográfica, no cālculo do comprimento devem ser medidos tanto os rios perenes como os canais intermitentes. Caso a medicão se restrinja aos cursos perenes, o resultado, além de falso, è maior em relação à pluviometria elevada e bem distribuỉda no decorrer do ano. Por outro lado, omitindo os canais fluviais intermitentes, notar-se-ia que nas regiões secas não haveria 
possibilidades de medicões e o cālculo seria nulo.

0 indice "freqüēncia de rios", tambēm proposto por HORTON (1945), representa o nümero de rios por unidade de ārea e é expresso pela förmula:

$$
F=\frac{N}{A}
$$

onde $\mathrm{N} \bar{e}$ o nūmero total de rios e $A \vec{e}$ a área da bacia hidrogrāfica:

De acordo com HORTON (1945) e SMITH (1950), os valores de densidade de drenagem e freqüencia de rios não podem ser. utilizados para a comparação direta entre ba cias com formas muito diferentes.

Para STRAHLER (1957), a comparação de bacias hidrográficas só é vālida se elas tiverem a mesma. ordem de ramịficação. Assim, utilizando o princīpio de anāli se dimensional e semelhança geométrica, elaborou um sistema de geomorfologia quantitativa, considerando que, havendo semelhança geométrica entre duas bacias, todas as medidas entre pontos correspondentes mantêm uma razão de escala fixa.

FRANCA (1968) aplicou a solos o método suge rido por STRAHLER (1957), para a selecão de bacias hidrogräficas atravēs da anālise dimensional. Tal método consis 
te na comparação de bacias de uma mesma unidade de solo,to madas duas a duas, confrontando-se suas caracterīsticas di mensionais.

0 sistema de classificação de ordens de ramificação proposto por HORTON (1945) e posteriormente adaptado por STRAHLER (1957), possibilitou a uniformização da anālise e comparação das redes de drenagem, condição in dispensāvel para se confrontarem elementos semelhantes.

Outro indice útil na diferenciação entre so. los è a razão de textura. Segundo CHRISTOFOLETTI (1969), o cálculo da textura da topografia vai representar o grau de entalhamento e dissecação da superfície terrestre. SMITH (1950) foi o primeiro a tecer conside rações para seu cālculo, baseando-se em mapas topogrāficos, anotando qùe a textura se expressava pela relação entre o nūmero de crênulas de determinada curva de nīvel, que : seria aquela contendo o maior nümero delas e o perīmetro da bacia.

A fórmula que representa a razão de textura è:

$$
T=\frac{N}{P}
$$

onde $N$ é o número de crênulas ou inflexões numa determinada curva de nível da bacia hidrogrāfica e $P$ é o perỉmetro 
da bacia. FRANCA (1968), adaptando esse indice para o estu do em fotopedologia, considerou $N$ como sendo o nümero de rios da bacia.

SMITH (1950), alēm da razão de textura em cada bacia hidrográfica, preconiza o seu valor médio ponde rado em relação à área, para caracterizar a textura topogrāfica em regiões uniformes quanto ao tipo de solo. A fōr mula proposta pelo autor $\overline{\mathrm{e}}$ a seguinte:

$$
\operatorname{Tm}=\frac{\sum(A \times T)}{\Sigma A}
$$

mantendo-se, para o estudo de solos em fotografias aēreas, a modificação de FRANÇA (1968), relativa à razão de textura.

A fim de obter padrões interpretativos para os valores obtidos, SMITH (1950) propôs parâmetros para a classificação da textura topográfica. Entretanto,como tais índices são referidos a perímetros expressos em milhas, FRANCA (1968) apresentou uma tabela correlacionando as razões de textura média, com indices expressos em milhas e em quilômetros (Tabela 1). 
Tabela 1 - Classificação da textura topográfica, para perỉmetro expresso em milhas e em quilômetros.

\begin{tabular}{lcc}
\hline \multirow{2}{*}{$\begin{array}{c}\text { CLASSE DE } \\
\text { TEXTURA } \\
\text { TOPOGRAFICA }\end{array}$} & \multicolumn{2}{c}{ RAZÃO DE TEXTURA MEDIA } \\
\cline { 2 - 3 } & $\begin{array}{c}\text { Përíme tro expresso } \\
\text { em milhas }\end{array}$ & $\begin{array}{c}\text { Perime tro expresso } \\
\text { em quilôme tros }\end{array}$ \\
\hline Grosseira & abaixo de 4,0 & abaixo de 2,5 \\
Mëdia & entre 4,0 e 10,0 & entre 2,5 e 6,2 \\
Fina & acima de 10,0 & acima de 6,2 \\
\hline
\end{tabular}

Segundo CHRISTOFOLETTI (1969), hā vārios fä tores naturais que influenciam na padronagem e densidade hidrográfica. o clima $\vec{e}$ o fator primeiro, pois fornece a massa liquida necessária à esculturação e estruturação da rede de drenagem; quanto à vegetação, o autor julga necessārio lembrar que nas āreas protegidas (recobertas por matas ou por pastagens), hâ o predominio do escoamento pluvial difuso, mas nas áreas de solos descobertos a concentração das águas de escoamento efetua-se rapidamente, resultando no aparecimento de uma drenagem finamente cinzela da. Nas condições climáticas quentes e úmidas, a litologia, principalmente pelo regolito que dela se origina, tem função importante, devido ao grau de permeabilidade. Nas áreas de regolito poroso, de rápida infiltração, a drenagemé pou 
co densa; ao conträrio, nas äreas de rochas pouco permeäveis, a densidade de drenagem è maior. Ainda segundo CHRI $\underline{S}$ TOFOLETTI (1969), a movimentação do relevo tambëm age como fator importante na densidade, pois as âreas de relevomais movimentado possuem trama mais densa dos canais, que nas äreas de relevo suave.

0 indice comprimento médio de rios, introdu zido por RAY e FISCHER (1960) em estudos litológicos e por FRANÇA (1968) em estudos de solos, relaciona o comprimento total ao nümero de segmentos de rios, sendo expresso pela förmula:

$$
\mathrm{Lm}=\frac{\mathrm{Lt}}{\mathrm{N}}
$$

STRAHLER (1957) verificou haver uma relação inversa entre os valores de comprimento medio de rios e den sidade de drenagem. CHRISTOFOLETTI e CESAR (1978) confirma ram tal fato, ao constatar que, com o aumento do valor da densidade de drenagem, ocorria uma diminuição quase propor cional do comprimento mēdio de rios.

FRANCA (1968) constatou que, entre outros elementos de drenagem, o comprimento mëdio de rios permitiu estabelecer diferenças entre os solos estudados. 
Para NOGUEIRA (1979), o comprimento médio de rios é.desnecessário para evidenciar diferenças entre unidades de solo, por expressar relação numérica entre outros indices mais eficientes.

Quanto ao sistema de amostragem, HORTON(1945) considerou cada bacia hidrográfica como uma unidade amostra1, critērio este adotado por vários pesquisadores que o sucederam.

RAY e FISCHER (1960) apresentaram o critērio de amostragem circular, destinado a trabalhos de carac terização litológica e adotaram amostras com tamanho equivalente a uma área de $10 \mathrm{~km}^{2}$. Segundo BURINGH (1960), essa ārea poderā variar entre 10 e $100 \mathrm{~km}^{2}$, em função da escala utilizada e do modo de ocorrência dos solos.

A Tabela 2 mostra os valores médios dos prin cipais indíces de drenagem obtidos por pesquisadores brasi leiros na área de fotopedologia, utilizando bacias hidrogrāficas como unidades amostrais. 
l'abela 2 - Valores médios dos principais indices de drenagem, para värios solos, utilizando bacias hidrográficas como unidadeś amostrais.

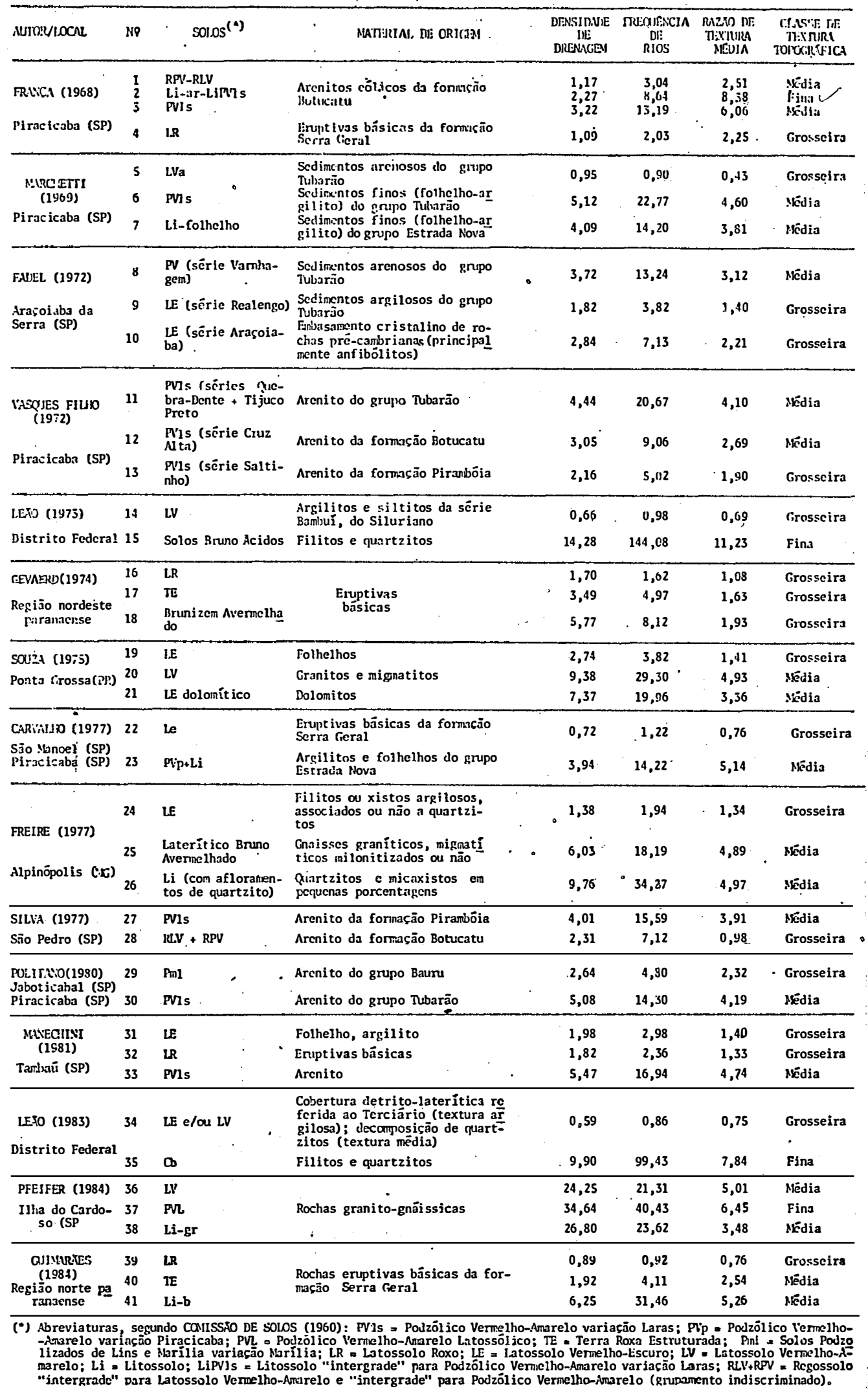


30 .

3. MATERIAL E METTODOS

3.1 - Material

3.1.1. - Caracterização do meio físico

3.1.1.1 - Localização geogräfica

A região do rio Ribeira de Iguape, no Estado de São Paulo, localiza-se na porção sul do litoral, con forme ilustra a Figura 1.

Fazem parte desta região, que estâ compreen dida entre os paralelos $23^{\circ} 45^{\prime} \mathrm{s}$ e $25^{\circ} 15^{\prime} \mathrm{s}$ e os meridianos $46^{\circ} 45^{\prime} \mathrm{W} \mathrm{Gr}$. e $49^{\circ} 30^{\prime} \mathrm{W} \mathrm{Gr}$., vârios municípios (parcial ou to talmente): Apiaí, Barra do Turvo, Cananéia, Eldorado, Igua pe, Iporanga, Itariri, Jacupiranga, Juquiâ, Juquitiba, Miracatú, Pariqüera-Açu, Pedro de Toledo, Registro, Ribeira, Sete Barras e Tapiraí. 


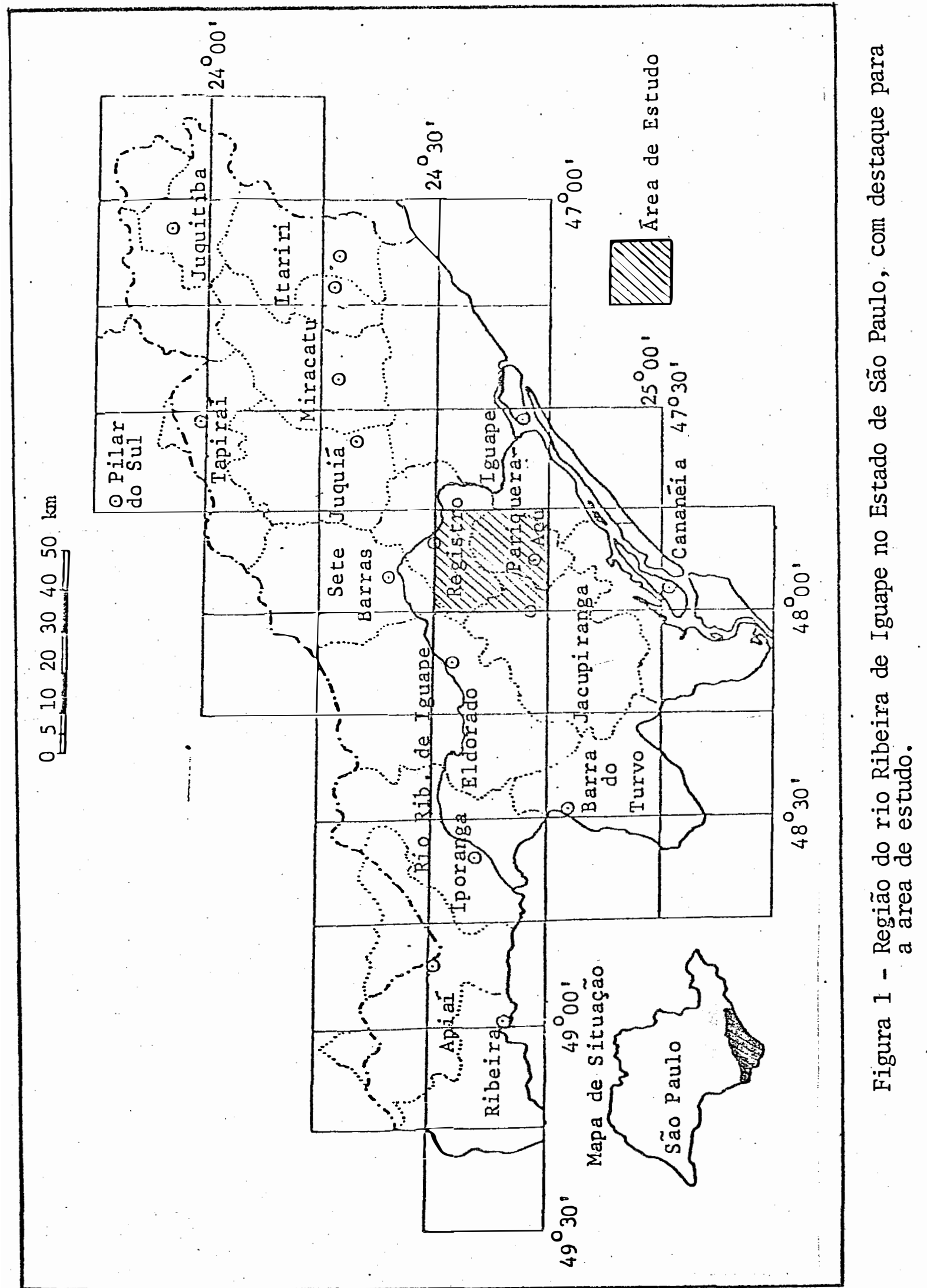


Dentro desta ampla região localiza-ze a ärea de estudo deste trabalho, mais especificamente entre os pa ralelos $24^{\circ} 30$ 'S e $24^{\circ} 45^{\prime} \mathrm{S}$ e os meridianos $47^{\circ} 45^{\prime} \mathrm{W} \mathrm{Gr}$. e $48^{\circ} 00 \cdot \mathrm{W} \mathrm{Gr}$. (Figura 1), correspondendo à folha topogräfica (INSTITUTO BRASILEIRO DE GEOGRAFIA E ESTATISTICA, 1974) de Pariqüera-Açu.

\section{$3.1 .1 .2-$ C1ima}

De acordo com a classificação de Köppen, o clima da área de estudo pertence ao tipo Cfa, ou seja, clí ma mesotërmico ümido, sem estiagem, em que a temperatura média do mês mais quente è maior do que $22^{\circ} \mathrm{C}$, apresentando o mês mais seco mais de $30 \mathrm{~mm}$ de chuva "(CAMARGo et alii, 1974).

RAMALHO e HAUSEN (1975) citam que o Vale do Ribeira é uma região de alta pluviosidade e de umidade do ar elevada e relativamente constante, que possibilitam a existência de densa cobertura vegetal tropical e de uma re de de drenagem farte e perene.

A concentração da pluviosidade nos meses de verao acarreta, como problema mais grave, a inundação dos terraços do rio Ribeira de Iguape e seus afluentes maiores, como o Juquiā e o São Lourenço, causando sérios danos às 
plantações de banana, uma das maiores riquezas da região. Os dados médios mensais de temperatura, pre cipitação pluvial e de resultados de balanço hídrico, bem como a representação gräfica do balanço hídrico, para o mu nicípio de Pariqüera-Açu, onde se encontra uma das estações experimentais do Instituto Agronômico, podem ser ,observados na Tabela 3 e Figura 2, respectivamente (CAMARGO et alii, 1974)。

Tabela 3 - Médias mensais de tenperatura, precipitação pluvial e de $\underline{\text { re }}$. sultados do balanço hỉdrico, segundo "Thornthwaite e Mather - 1955" (125 mm), para o município de Pariqüera-Açu - SP.

\begin{tabular}{|c|c|c|c|}
\hline \multirow{2}{*}{ ME S E S } & \multicolumn{3}{|c|}{$\begin{array}{l}\text { Pariqüera-Açu - SP } \\
\text { Lat. } 24^{\circ} 35^{\prime} \mathrm{S} \\
\text { Long. } 47050^{\prime} \mathrm{W}\end{array}$} \\
\hline & $\begin{array}{l}\text { Temperatura } \\
\text { média }\end{array}$ & $\begin{array}{c}\text { Precipitação } \\
\text { pluvial }\end{array}$ & $\begin{array}{l}\text { Balanço } \\
\text { hídrico }\end{array}$ \\
\hline 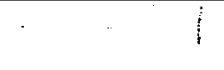 & ${ }^{\circ} \mathrm{C}$ & $\mathrm{nm}$ & $\mathrm{mm}$ \\
\hline $\begin{array}{l}\text { Janeiro } \\
\text { Fevereiro } \\
\text { Março } \\
\text { Abri1 } \\
\text { Maio } \\
\text { Junho } \\
\text { Ju1ho } \\
\text { Agosto } \\
\text { Setembro } \\
\text { Outubro } \\
\text { Novembro } \\
\text { Dezembro }\end{array}$ & $\begin{array}{l}25,9 \\
26,2 \\
25,3 \\
23,1 \\
20,5 \\
18,8 \\
18,8 \\
19,6 \\
20,4 \\
22,1 \\
23,2 \\
24,7\end{array}$ & $\begin{array}{r}266 \\
234 \\
199 \\
117 \\
68 \\
76 \\
62 \\
56 \\
99 \\
145 \\
140 \\
165\end{array}$ & $\begin{array}{r}+75 \\
+\quad 101 \\
+\quad 73 \\
+22 \\
0 \\
+28 \\
+12 \\
0 \\
+24 \\
+50 \\
+30 \\
+32\end{array}$ \\
\hline ANO & 22,4 & 1.587 & $\begin{array}{r}+447 \\
0\end{array}$ \\
\hline
\end{tabular}

Fonte: CAMARGO et alii (1974)。 
34 .

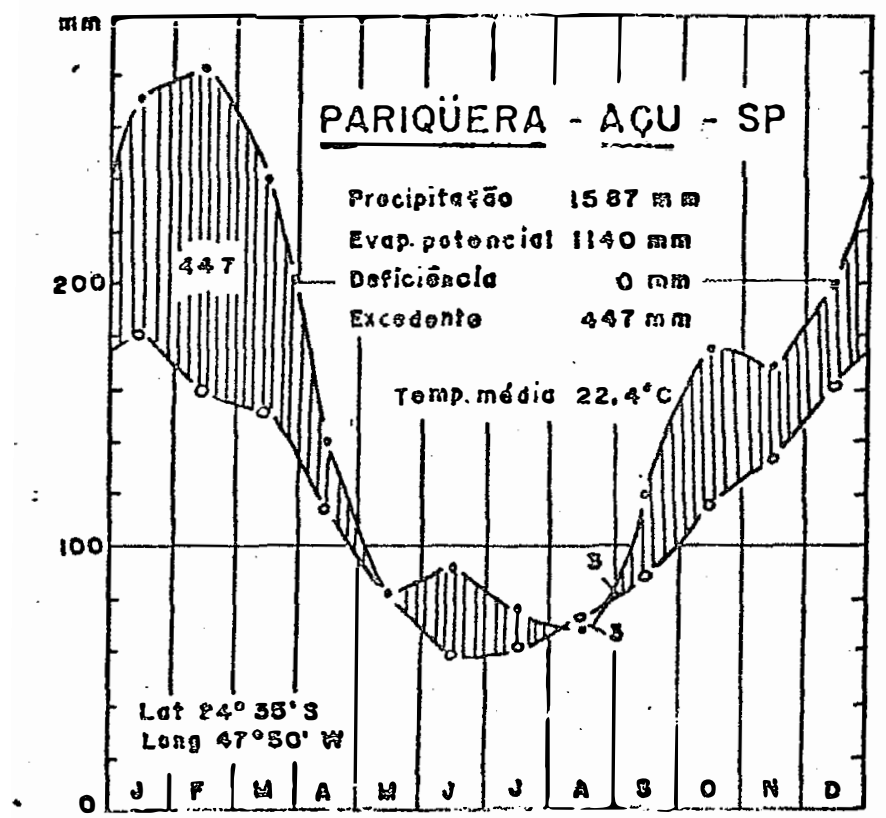

Figura 2 - Balanço hỉdrico pelo mëtodo de "Thornthwaite e Mater - 1955" $(125 \mathrm{~mm})$, para o município de Pariqüera-Açu - SP. Fonte: CAMARGO et alii (1974). 


\section{$3 \cdot 1.1 .3-$ Geologia}

Do mapeamento geológico executado por MOR-

GENTAL e BATOLLA JR. (1974) destacam-se, na ärea de estudo, três ocorrências de importância: a) migmatitos e xistos ou filitos (Pré-Cambriano); b) formação Pariqüera-Açu (Pleistoceno); e c) formações fluviais e flüvio-marinho-lacustres (Holoceno) .

a) Migmatitos e xistos ou filitos

Os migmatitos estão, segundo RAMALHO e HAUSEN (1975) entre as rochas mais antigas do Vale do Ribeira, juntamente com. gnaisses, granitos de anatexia, anfibólitos, quartzitos e märmores dolomiticos, todas pertencentes ao Complexo Gnáissico-Migmatítico, do Pré-Cambriano Médio a Superior .

Os gnaisses e migmatitos da região são, de acordo com MELFI et alii (1965), paragnaisses originados por metamorfismo de grau mais alto a partir dos mesmos sedimentos que produziram os filitos e micaxistos. São rochas fitadas, formadas por bandas claras de quartzoe feld $\underline{s}$ patos e escuras de anfibólio e biotita, de espessura centimëtrica。 
Os filltos e micaxistos, ao lado de mârmores calcíticos e dolomiticos, metassedimentos silltico-argi losos e siltico-arenosos, metassiltitos e quartzitos, pertencem ao Grupo Açunguí Indiferenciado, do Pré-Cambriano Superior (RAMALHO e HAUSEN, 1975). MELFI et alii (1965) ob servaram que, de modo geral, hả uma transição gradual de filitos para micaxistos, de oeste para leste, indicando um aumento contínuo do grau de metamorfismo neste sentido.

As rochas de idade prë-Cambriana e as intru sivas graníticas subseqüentes foram submetidas a uma tectô nica rígida intensa, que se expressa pela razoảvel quanti-. dade de falhamentos e fraturamentos (RAMALHO e HAUSEN,; 1975).

b) Formação Pariqüera-Açu

A formação Pariqüera-Açu assenta discordantemente sobre as rochas do complexo migmatítico. Formou-se no Quaternário (P1eistoceno), quando da deposição de sedimentos com seixos e fragmentos arredondados de quartzo e quart zito, imersos em matriz sítico-areno-argilosa, morfologicamente dispostos em terraços localizados em níveis de 25 a 40 metros, acima do atual 1eito do rio Ribeira de Iguape e de alguns afluentes (RAMALHO e HAUSEN, 1975).

$\mathrm{Na}$ base desta formação ocorre um conglomera do arcoziano com seixos e calhaus, predominantemente de 
quartzitos de diversos tipos: grosseiros, finos, xistosos, fibrosos, com predomínio de cores claras. O grau de arredondamento varia nos afloramentos, podendo encontrar-se ar redondados até angulosos, porém com distribuição homogênea; em cotas mais inferiores os seixos tendem a ser mais arredondados. Seixos e calhaus de quartzo tambëm ocorrem, porêm de forma sempre subordinada; qualitativamente pode-se dizer que a razão do número de seixos de quartzitos para o número de seixos de quartzo tende a decrescer conforme diminui o tamanho dos seixos no afloramento.

Sobrepõe-se ao conglomerado um depósito argiloso de cor marrom amarelada, com grânulos e seixos de quartzo esparsos na matriz. Este depósito é inconsolidado, bastante homogêneo, maciço, com ampla extensão lateral, de aspecto semęlhante aos sedimentos da Formação Rio Claro e/ ou Formação Piraçununga. Um arenito quartzoso médio,de cor cinza claro e matriz argilosa, semi-consolidado, possui ocorrência em äreas restritas, como a que ocorre próxima ao Campo de Pouso de Registro. Sob este arenito, o conglomerado basal da formação possui cor cinza claro. Sedimentos argilosos, de cores mescladas, ocorrem com pequena expressão 1ateral; areia grossa e grânulos encontram-se dispersos na matriz, possuindo aspecto maciço (PRESSINOTTI e PRESSINOTTI, 1980) . 
c) Formações fluviais e flúvio-marinho-lacustres.

A planície fluvial do baixo Ribeira estende-se de Sete Barras atê o contato com as restingas da cos ta, penetrando pelos vales do Pariqüera-Açu, do Jacupiranga e do Juquiā. E constituída de sedimentos argilo-arenosos e/ou areno-argilosos e ocupa um vasto terraço situado 2,0 a 6,0 metros acima do nível do rio. A partir de Registro estes sedimentos recobrem os depósitos marinhos e lagunares do fundo da paleo-baía. O rio Ribeira divaga dentro des sa planície, deixando ao longo de seu curso inúmeros lagos: e meandros ("deixas"), jā quase totalmente colmatados. Essas formações são de idade holocênica (RAMALHO e HAUSEN, 1975) •

0 mapa geológico da ārea de estudo e a ćolu na estratigráfica do Vale do Ribeira são mostrados, respec tivamente, na Figura 3 e na Tabela 4. 


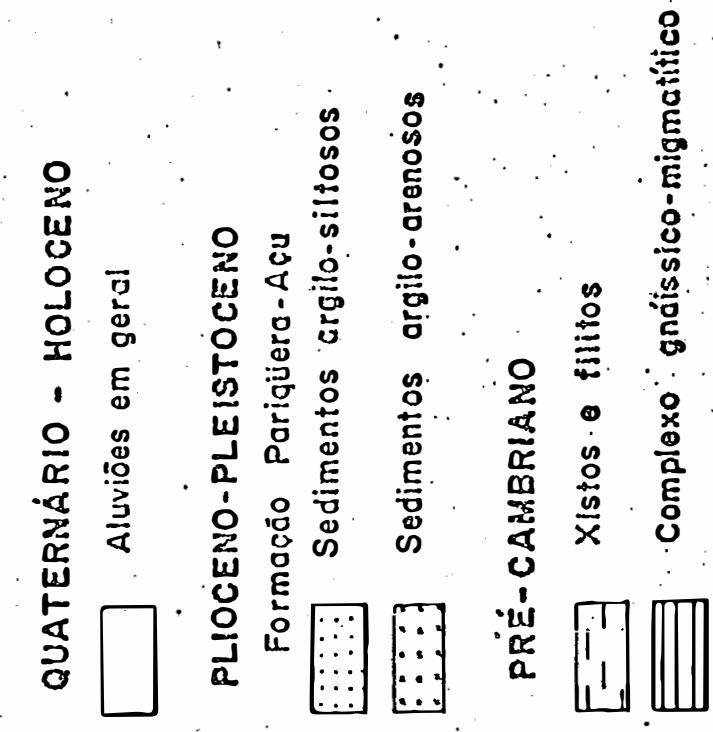

39.

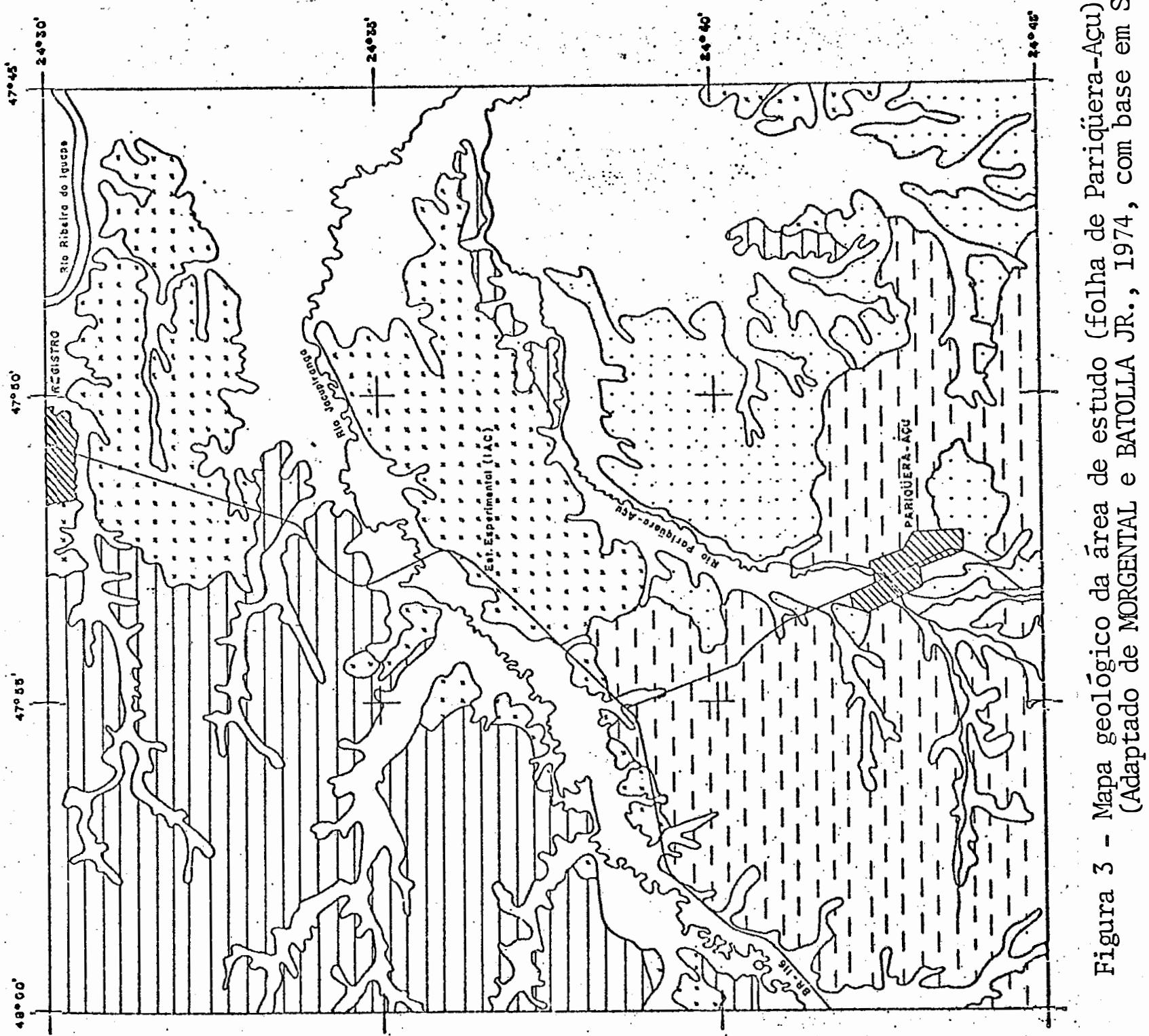


40.

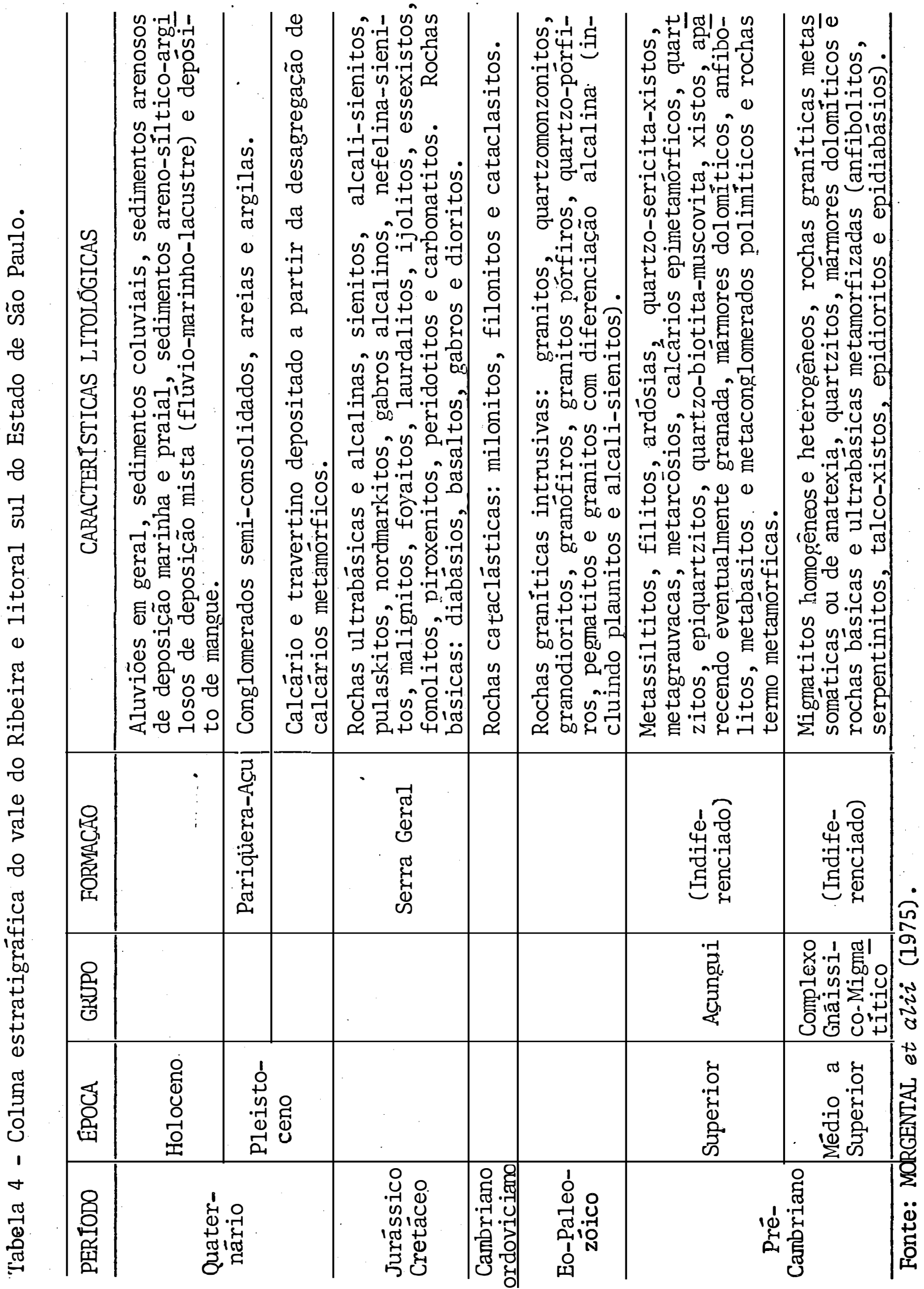




\subsubsection{4 - Geomorfologia e relevo}

RAMALHO (1974) definiu quatro compartimentos que, basicamente, constituem o relevo da ärea de estudo: a) planícies aluviais; b) baixo nive1 de colinas com altitudes até 60 metros; c) morros e colinas, nível inferior, altitudes entre 60 e 100 metros; e d) espigões e mor ros do nivel intermediärio, com altitudes entre 100 e 300 metros.

As planícies aluviais estão associadas às formações fluviais e flûvio-marinho-lacustres, do período quaternário (Holoceno).

o baixo nivel de colinas, com altitudes atë 60 metros, aparece na baixada litorânea, na região das colinas sub-1itorâneas e está associado à Formação Pariqüera-Açu. Segundo PRESSINOTTI e PRESSINOTTI (1980), a bacia de sedimentação desta formação deve ter sido preenchida quando o r̉io Ribeira já fluia para o Atlântico; esta ba cia seria circumpiemôntica, em que a face sudeste, voltada para a costa, seria limitada por barreiras de direções E-W e NE-SW, que serviram para o represamento dos sedimentos.

Nesta ārea, flutuações climáticas entre os climas semi-ârido e úmido teriam atuado na formação dos ter raços fluviais. Em ëpocas semi-äridas ocorreria um aplaina 
mento intermontano; quando ocorresse uma mudança climätica, em direção ao úmido, haveria uma dissecação ao longo dosi ca nais de drenagem, com o rebaixamento do nível de base 1ocal. Em um estágio posterior, quando nova mudança climática se efetuasse para condições semi-äridas, haveria um aplainamento lateral formando, então, os terraceamentos, que manteriam estreito correlacionamento com a rede de drenagem. Esse as pecto é mostrado ao longo do rio Ribeira, rio Jacupiranga e rio Carapiranga, próximo a Registro, onde tem-se bem definidos os terraços preenchidos por sedimentos argilosos e turfas que caracterizam o clima úmido atual. Esse terracea mento teria ocorrido em época pretérita, em fins do Pleistoceno.

Os morros e colinas do nível inferior (a1t $\underline{i}$ tudes entre 60 e 100 metros) e os espigões e morros do nível intermediärio (altitudes entre 100 e 300 metros), compõem a região denominada "pré-serrana". Essa região é uma ārea de transição entre o planalto e a baixada e apresenta, a partir da calha do rio Ribeira, uma sucessão de morros e espigões, que representam os primeiros contrafortes do pla nalto. Por representar uma ruptura de relevo, entre a escarpa do planalto e a baixada, a região pré-serrana provoca a suavização de gradiente dos rios, ocasionando a deposição de sedimentos em largas planícies aluviais, que se abrem em 
a1vêolos no sopë da vertente da serra.

\subsubsection{5 - Vegetação primitiva e uso atual da terra}

Originalmente, a maior parte da ārea de estudo era coberta pela floresta latifoliada tropical pereni fólia. Ela ê, conforme citam RAMALHO e HAUSEN (1975), a for mação vegetal principal da bacia do Ribeira. Desenvolve-se das partes altas da serra ate as encostas e parte da baixa da, alcançando o litoral através dos espigões da Serra de Paranapiacaba. 0 seu desenvolvimento estâ ligado ao clima, isto ê, relacionado à intensa umidade da ârea.

SAKAI e LEPSCH (1984) citam algumas espëcies comuns desse tipo de floresta: angelim-de-espinho ( $A \underline{n}$ dira spinulosa); angelim-rosa (Platycyamus regnelzi); ange lim-araroba (Valaireopis araroba); araribä (Centrobolium to mentosum); cabriúva-branca (Myrocarpus frondosus); canela-sassafrás (Ocotea sassafras); canelinha (Ocotea puZchelza); guapuruvu (Schizolobium parahybum); guatambu (Aspidosperma olivaceum); indaiâ (AtaZleaspp.); ipê (Tabebuia spp.); jacarandä-paulista (Machaerium vizlosum); jequitibä-vermelho (Cariniana legalis); manacá (Brunfelsia hopeana); manacâ-da-serra (Tibouchina mutabilis); palmito-branco (Euterpe edulis); pau-ferro (Caesalpinia ferrea) e peroba-rosa (Aspidosperma pozyneuron)。 
Outro tipo de vegetação comum na ärea è a vegetação higröfila, ou vegetação de banhado (RAMALHO e HAUSEN, 1975). Desenvolve-se nas äreas de baixada, saturadas de âgua, chamadas popularmente de "varjões". Esses"var jões" são ocupados por vegetação herbäcea e por bosques nas äreas menos saturadas.

Com relação ao uso da terra, atualmente a floresta encontra-se em boa parte substituída por "capoeiras" (mata secundâria), pastagens e cultivos diversos, com destaques para o châ (Thea sinensis) e a banana. Outros cultivos tambêm encontrados são o da seringueira, do cacau, do milho, do arroz e de plantas frutícolas e olerícolas. . As âreas de mata secundāria ("capoeiras") aparecem em decorrência da agricultura itinerante, com a derrubada da mata, queimada, cultivo e abandono após o esgotamento do solo.

\section{$3.1 .1 .6-$ Hidrografia}

Em consequência do clima uึmido com alta pre cipitação e da perda mínima de àgua por evaporação, a rede de drenagem é extremamente densa. Três fatores favorecem es ta abundância de drenagem: clima, vegetação e litologia. 0 clima fornece um grande excedente hídrico para alimenta- 
ção dos rios. Protegida pelo denso manto vegetal, a ägua de escoamento está a salvo de uma evaporação exagerada e, sendo a litologia composta de rochas que originam, em sua maioria, solos pouco profundos, fica favorecido o escoamen to sub-superficial, impedindo assim a infiltração profunda da âgua, mantendo a perenidade dos rios.

0 rio.Ribeira de Iguape ê, no seu curso mêdio e alto, um rio típico de planalto, possuindo um curso acidentado, com inümeras corredeiras e abrindo profundos va les em $V$ na sua descida para a baixada. A jusante de Iporanga, onde o rio alcança a cota dos 60 metros, o gradiente se suaviza, apresentando, dai em diante, um curso tipico de rio de planície (RAMALHO e HAUSEN, 1975).

\section{$3.1 .1 .7-$ Solos}

Pelo exame da carta de solos da folha $24^{\circ} 15^{\prime} \mathrm{S}$ $-24^{\circ} 45^{\prime}$ S e $47^{\circ} 30$ 'W Gr. $-48^{\circ} 00$ 'W Gr. (Registro, Juquiā, Pariqüera-Açu e Iguape), do Levantamento Pedológico de Reconhemento-Semidetalhado da Região do Rio Ribeira do Iguape no Estado de São Paulo (SAKAI et alii, 1983), foram seleciona das para este estudo, pela sua importância regional, cinco unidades de mapeamento, classificadas ao nível de fases de Grandes Grupos, que são as seguintes: 
a) LAa: Latossolo Amarelo álico A moderado textura ar gilosa fase floresta tropical perenifólia relevo suave ondulado (unidade Pariqüera);

b) PVLa-1: Podzólico Vermelho-Amarelo Latossólico ả1 í co A moderado textura argilosa/muito argilosa fase floresta tropical perenifólia relevo ondulado (un dade Taquaruçu);

c) PVLa-2: Podzó1ico Vermelho-Amarelo Latossó1ico ả1 $\underline{i}$ co A moderado textura média/argilosa fase floresta tropical perenifólia relevo suave ondulado (unidade Arataca);

d) PVa: Podzólico Vermelho-Amarelo Tb ảlico A moderado textura média/argilosa fase floresta tropical perenifólia relevo ondulado (unidade Vapamirim);

e) Ca-2: Cambissolo Tb älico A moderado textura argilosa fase floresta tropical perenifólia relevo for te ondulado e montanhoso substrato filito e xisto (unidade Canfilito).

Além destas cinco unidades principais,ocorrem na ärea de estudo outras de menor expressão, a saber: Glei Pouco Hümico Tb älico textura argilosa fase campo tro pical hidrōfilo de vārzea (unidade Cinza); associação Solo 
Orgânico Distrófico ou Alico (unidade Taruru) + Solo Orgânico Distrófico (soterrado) A moderado (unidade Gleiruru) + Glei Indiscriminado ambos fase floresta tropical higrófila e campo hidröfilo de vârzea; associação Solo Orğânico Endotiomörfico (unidạde Tarutio) + Glei Indiscriminado ambos fase floresta tropical higrófila e campo hidrófilo de várzea relevo plano; grupamento indiferenciado de Podzólico Vermelho-Amarelo Ta älico A moderado textura arenosa/mé dia (unidade Samba) e solo Podzölico Indiscriminado textura arenosa com lamelas (unidade Areia) fase relevo plano floresta tropical de vârzea.

A distribuição geogräfica das diversas unidades de mapeamento na ärea de estudo é mostrada na Figura 4; e a distribuição das cinco unidades estudadas, em função do relèvo e do material de origem, está esquematizada na Figura 5 .

Os resultados de anâlise de amostras de so10 (médias e respectivos erros padrões), das cinco unidades selecionadas para este estudo, encontram-se na Tabela 5.

Nas Tabelas 6 a 10 estão descritas as principais caracteristicas morfológicas dos perfis das cincoun $\underline{i}$ dades estudadas; e na Tabela 11 são apresentadas as princ pais caracteristicas morfológicas e funcionais desses solos. 


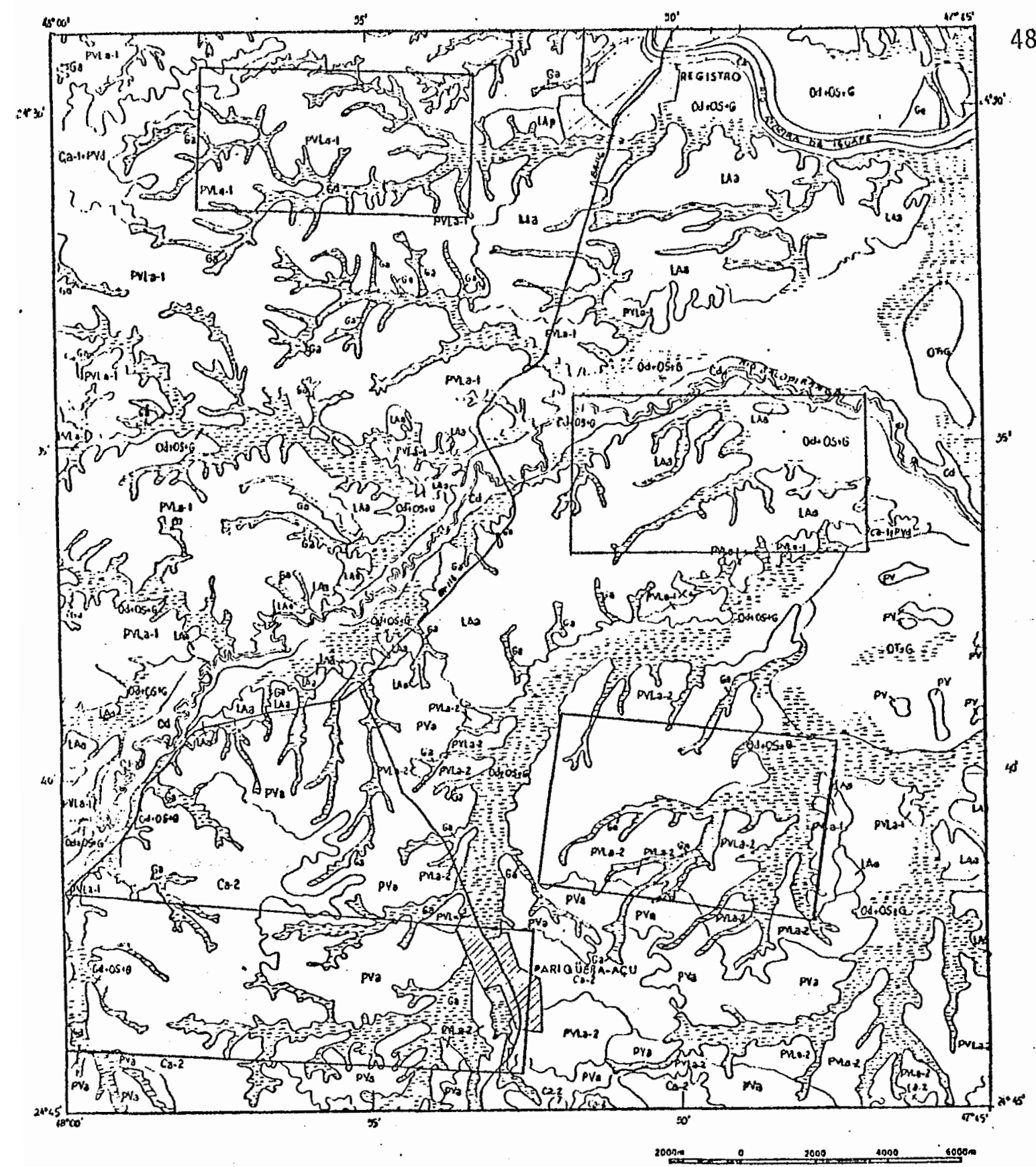

Figura 4 - Mapa de solos da ärea de estudo (folha de Pariqüera-Açu). (Extraído de SAKAI et alii, 1983).

LAa = Latossolo Amarelo ālico; PVLa-1 = Podzólico Vermelho-Amarelo Latossólico âlico; PVLa-2 = Podzólico Vermelho-Ama relo Latossólico âlico; PVa = Podzólico Vermelho-Amarelo $\overline{\mathrm{a}-}$ lico; PV = grupamento indiferenciado de Podzólico Vermelho-Amarelo älico e Podzólico Indiscriminado; $\mathrm{Cd}=$ Cambissolo distrófico; $\mathrm{Ca}-2$ = Cambissolo álico; Ga = Glei Pouco Hưmico âlico; Od = Solo Orgânico distrófico; $O d+O S+G=$ Solo Orgâni co distrófico ou âlico + Solo Orgânico distrófico + Glei In discriminado; OT $+\mathrm{G}=$ Solo Orgânico Endotiomórfico + Gleĩ Indiscriminado. 


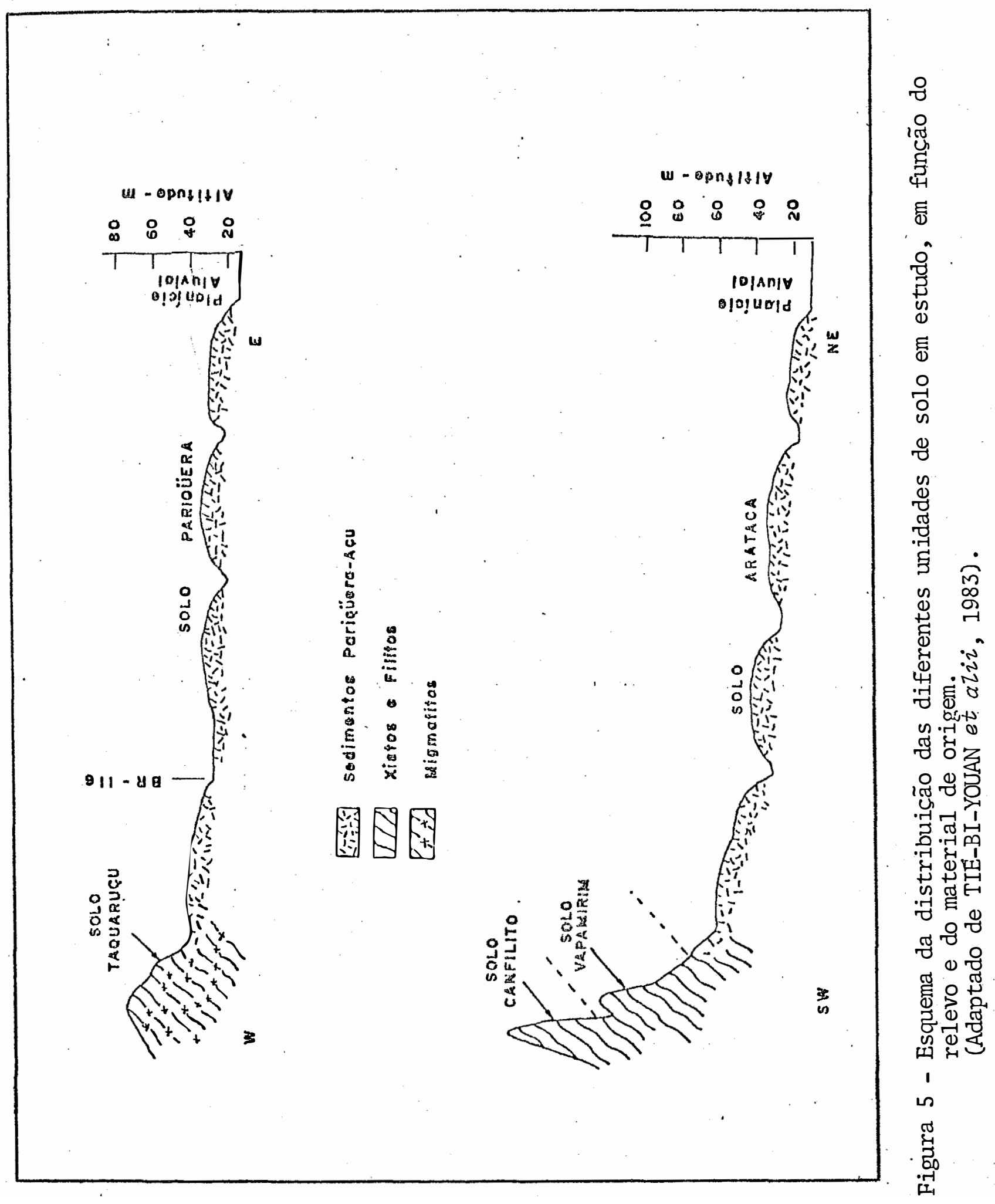




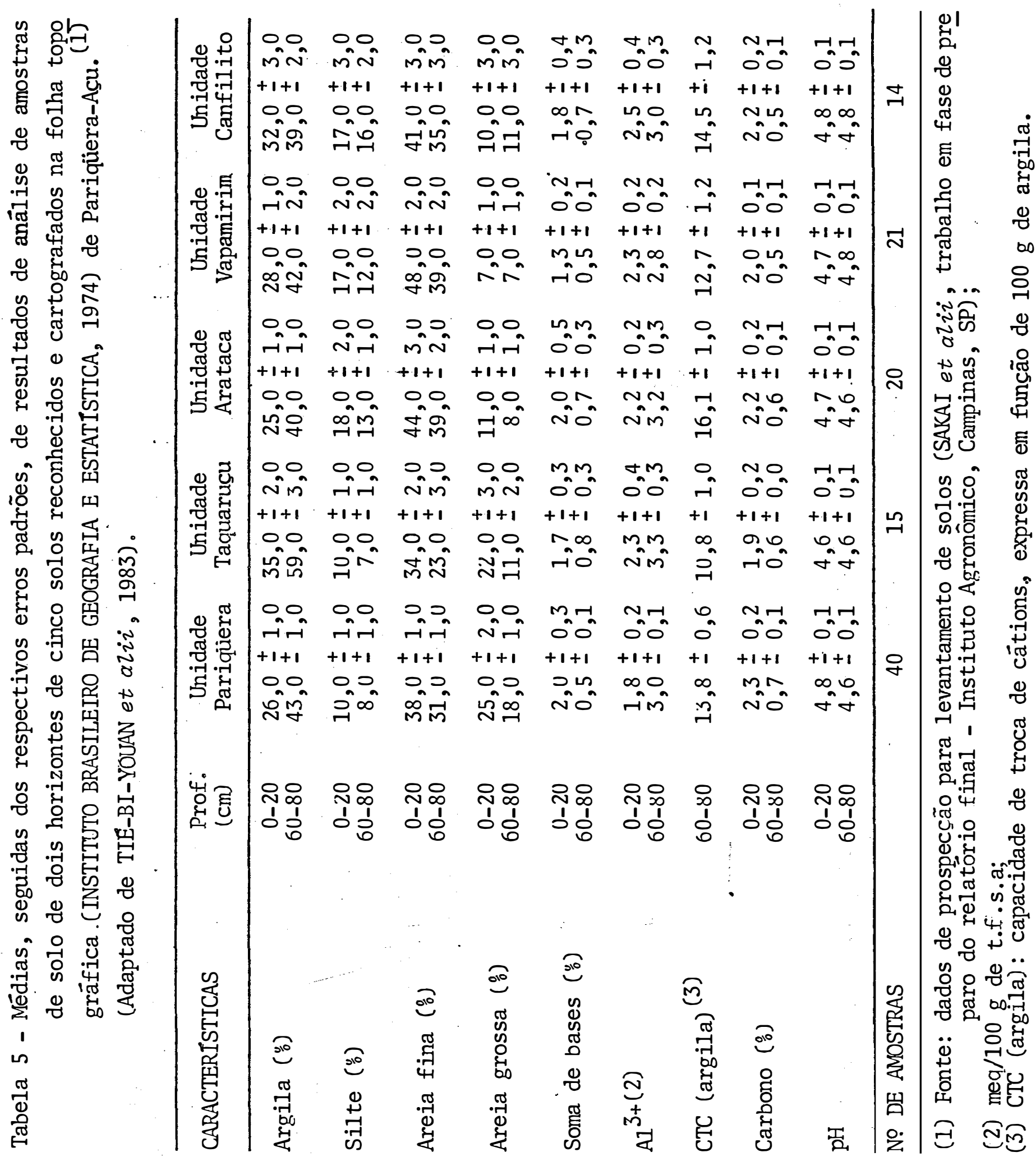




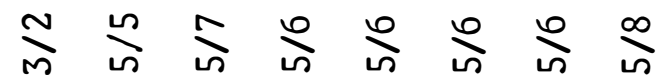
先 
토

苗

宅

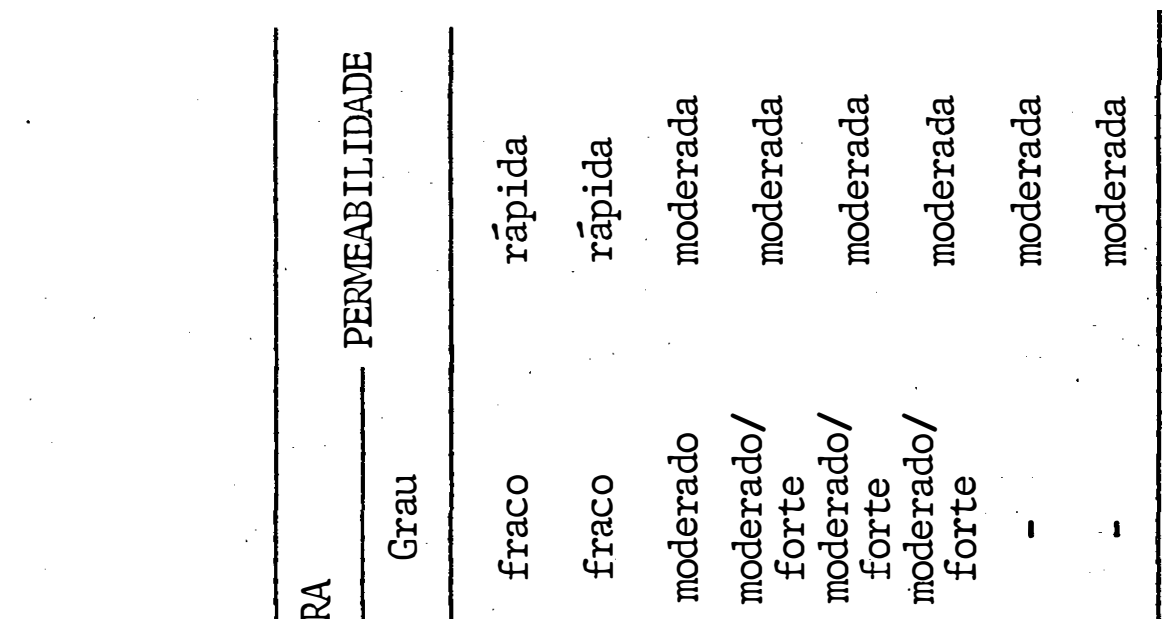

త్రి

.9

它

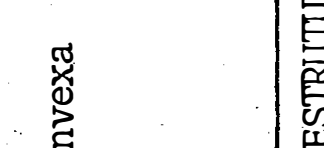

象

ช

:

芯 过

ช

空 究

政

i

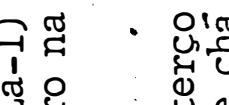

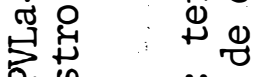

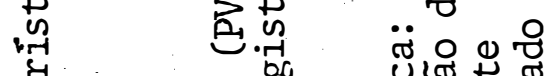

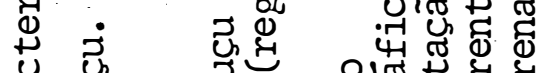

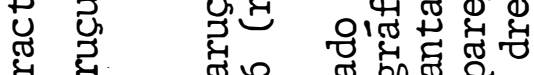

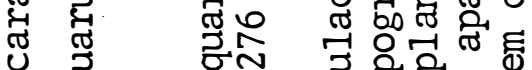

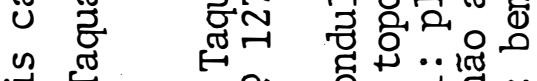

.

.

บ

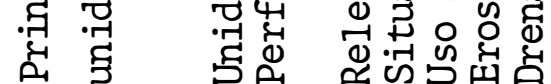



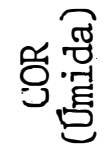

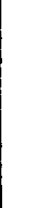

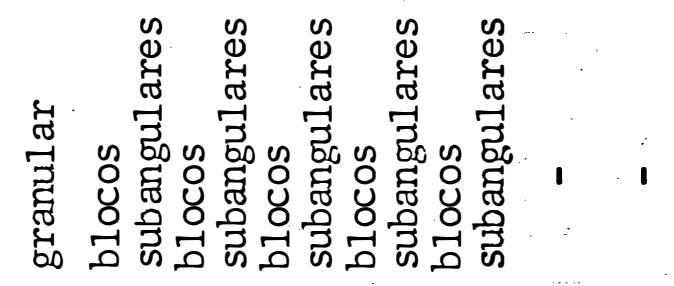

论

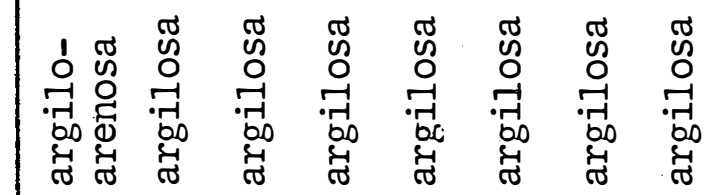

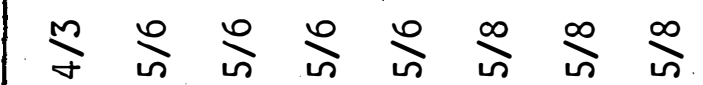

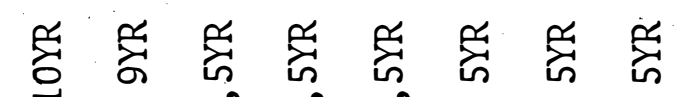

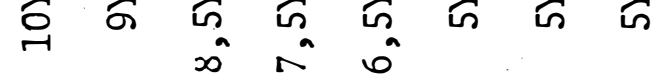

* $\circ$ 용

○

穵

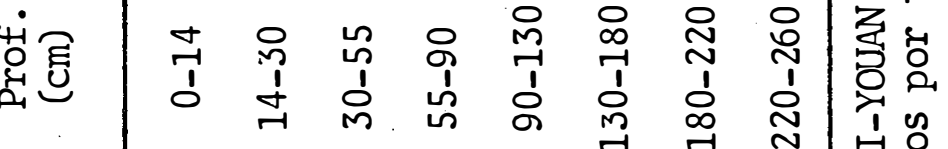

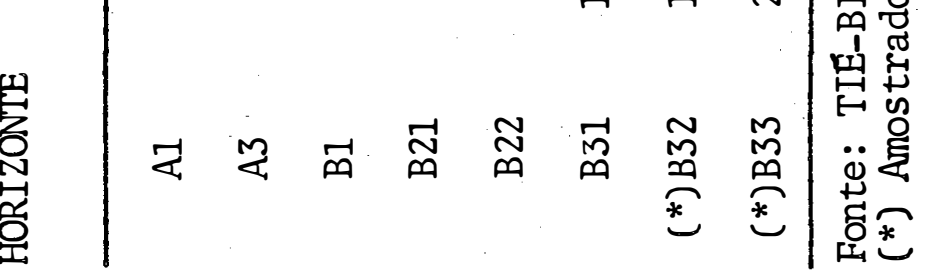




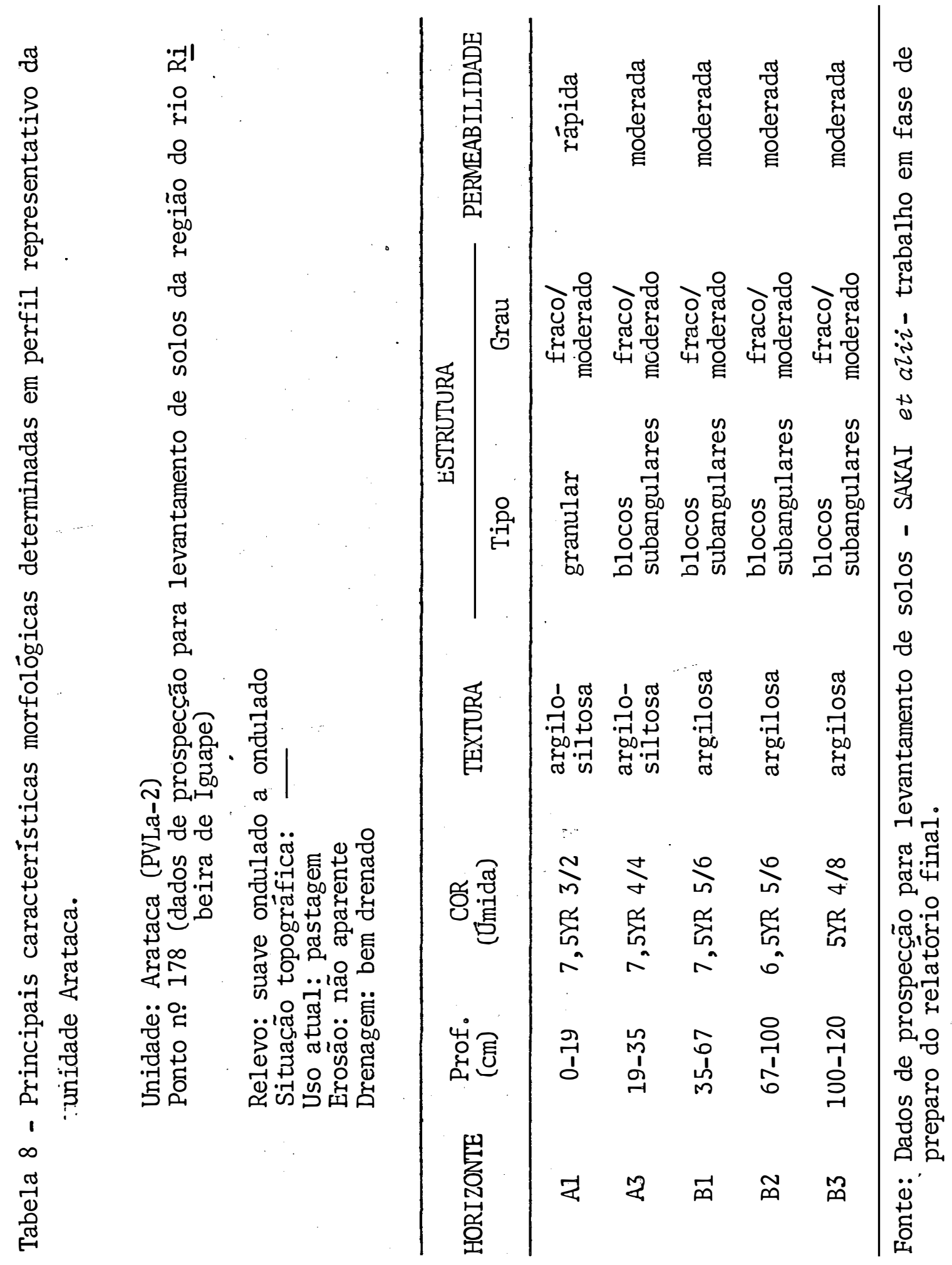


54.

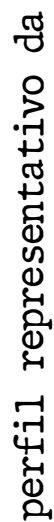

ต

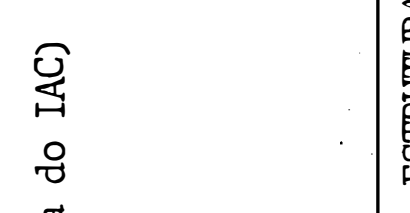

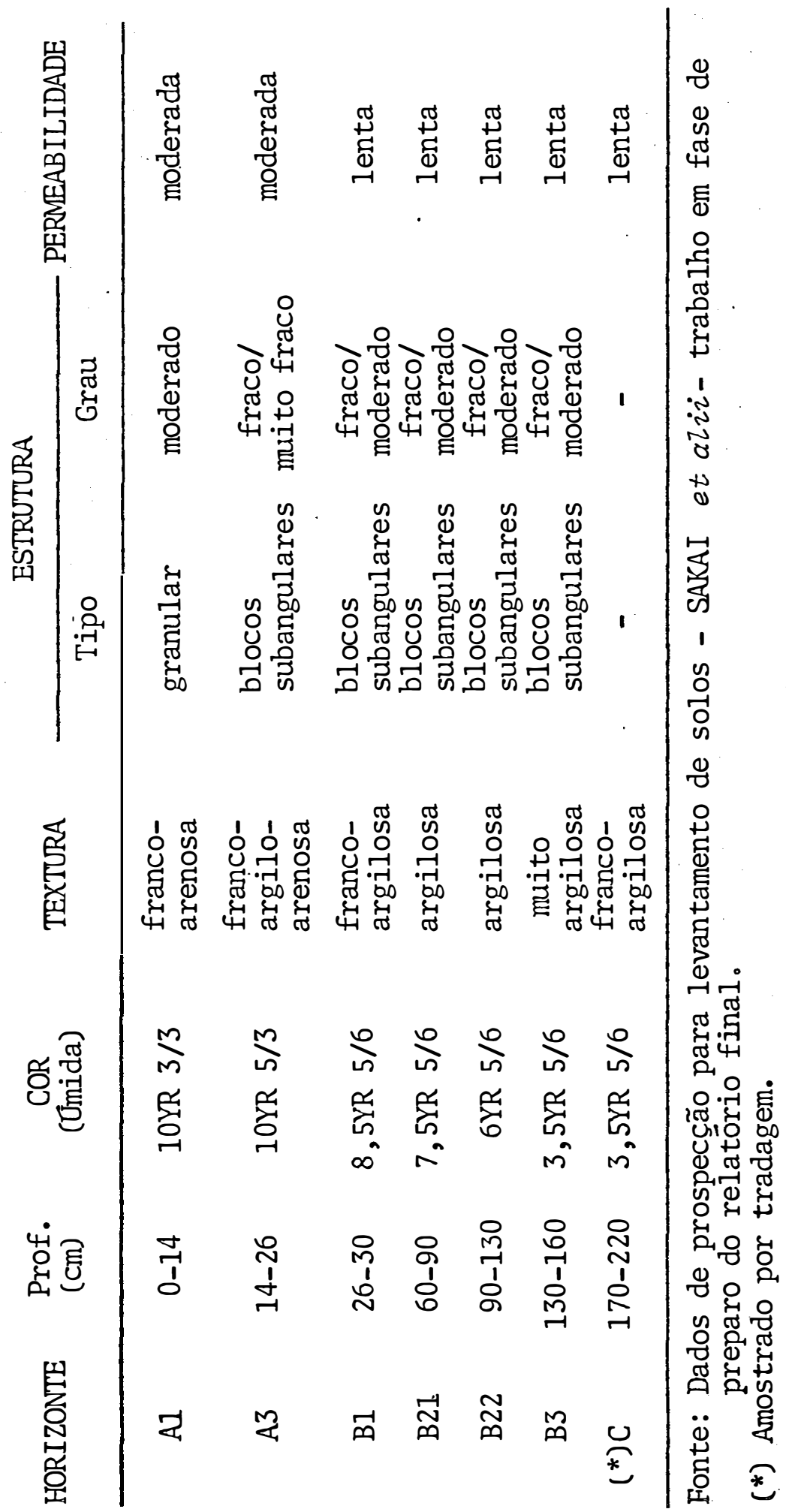


55.

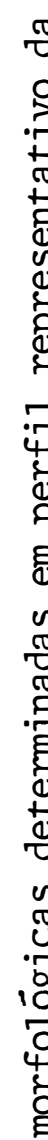

శึ

劲

ฮี

لृ

ชึ่

00
10
0
4
4
0
0

ช

$\stackrel{\leftrightarrow}{\longrightarrow}$

?ח.

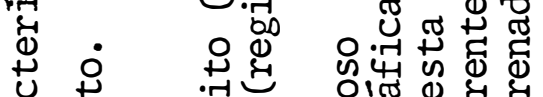

:

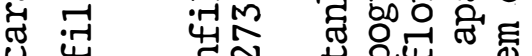

范 苂

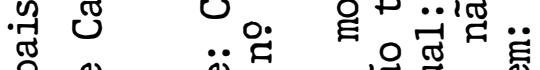

㑒

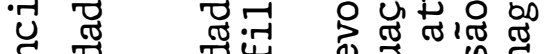

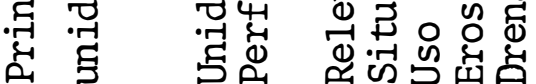

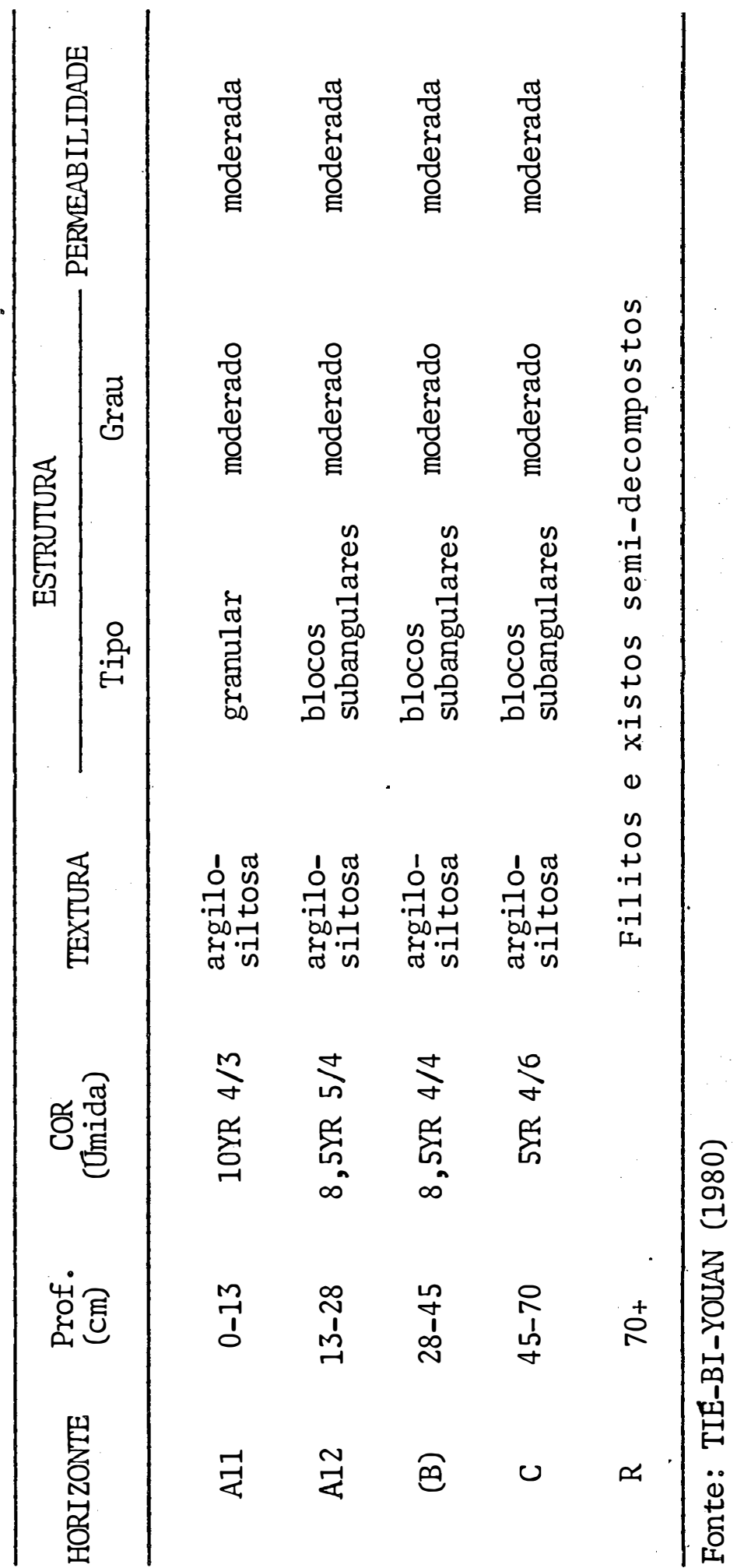


56.

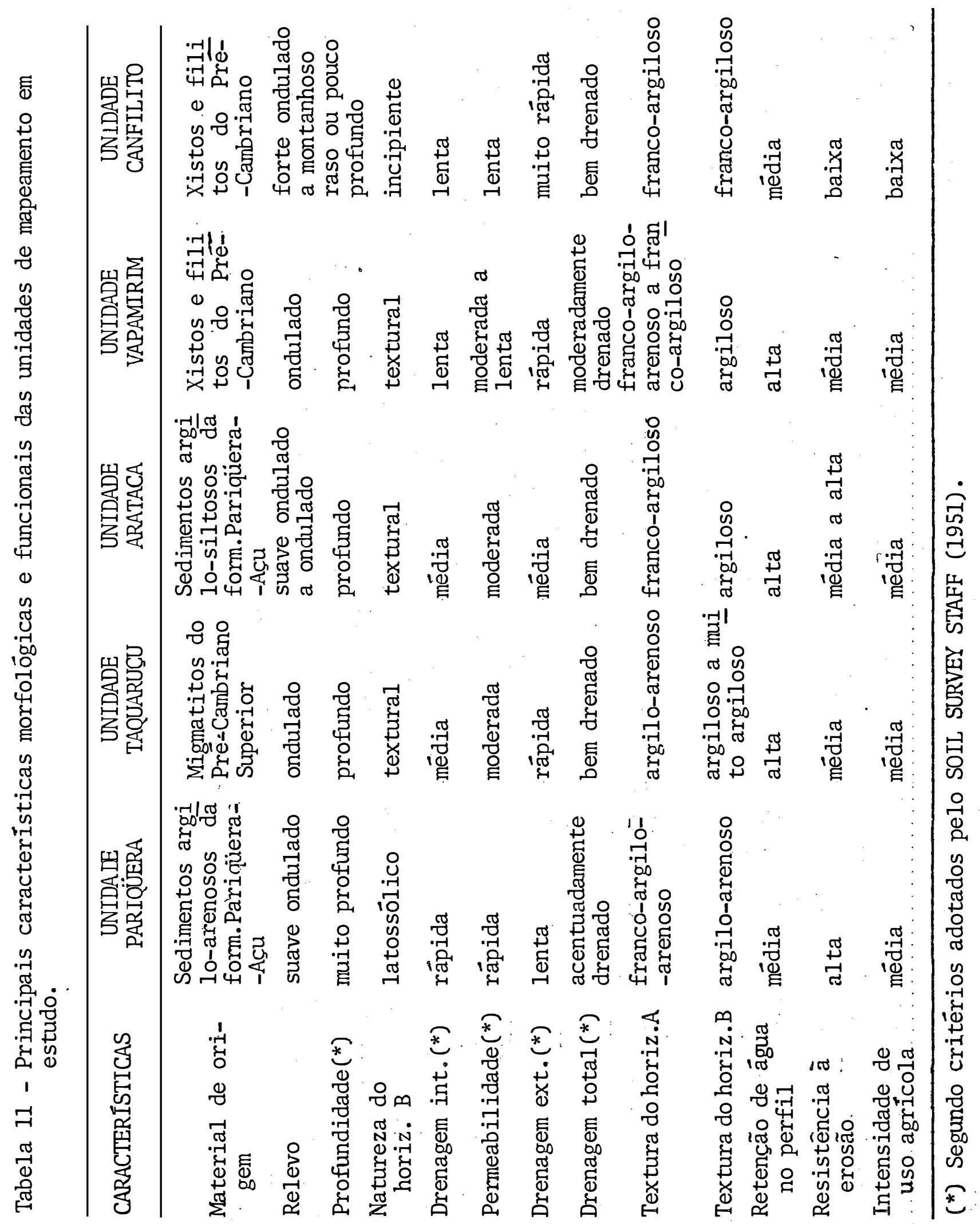


57.

\section{1 .2 - Material cartográfico}

$\mathrm{Na}$ execução deste trabalho foram utilizadas as seguintes cartas:

a) Folha Pariqüera-Açu (SP), SG-23-V-A-IV-1, do IBGE (Superintendência de Cartografia), na escala 1:50.000;

b) Mapa geomorfológico da folha Pariqüera-Açu, PROJETO SUDELPA, na escala 1:50.000;

c) Mapa geológico da folha Pariqúera-Açu, PROJETo SUDELPA, na escalá 1:50.000;

d) Carta de solos da folha $24^{\circ} 15^{\prime} \mathrm{S}-24^{\circ} 45^{\prime} \mathrm{S}$ e $47^{\circ} 30^{\prime} \mathrm{W}$ Gr. - $48^{\circ} 00^{\prime} \mathrm{W} \mathrm{Gr}$. (Registro, Juquiā, Pariqüera-Açu e Iguape), do Levantamento Pedológico de Reconhec $\underline{i}$ mento-Semidetalhado da Região do Rio Ribeira do Iguape no Estado de São Pau1o, na escala 1:100.000. 


\section{1 .3 - Material fotogräfico}

Foram utilizadas fotografias aéreas verticais pancromáticas, provenientes da cobertura aerofotogramétrica de parte do Estado de São Paulo (1972/73), executa da pela VASP AEROFOTOGRAMETRIA S/A, para a Secretaria da Agricultura do Estado de São Paulo. As cónias empregadas na fase de interpretação fotogräfica deste trabalho perten cem à Seção de Fotointerpretação do Instituto Agronômico e apresentam as seguintes características:

- Escala aproximada: 1:25.000;

- Dimensões: $23 \mathrm{~cm} \times 23 \mathrm{~cm}$;

- Area abrangida por fotografia: aproximadamente $33 \mathrm{~km}^{2}$;

- Recobrimento aproximado: 60\% entre fotografias . na faixa de vôo e $30 \%$ entre fotografias de faixas adja centes.

A identificação das fotografias que recobrem as äreas de interesse específico, dentro da ärea de estudo, foi feita atravês de exame do fotoindice e dạ carta de solos da região, ambos na escala $1: 100.000$, resultan do na seguinte seleção:

a) Unidade Pariqüera (LAa)

Fotografias: 50.076 a 50.079

Faixa de vôo: 324 D

Data: $09-08-73$ 
59.

b) Unidade Taquaruçu (PVLa-1)

Fotografias: 48.775 a 48.780

Faixa de vôo: 322D

Data: 08-07-73

c) Unidade Arataca (PVLa-2)

Fotografias: 50.140 a 50.143

Faixa de vôo: 326D

Data: 09-08-73

d) Unidade Vapamirim (PVa)

Fotografias: 50.179 a 50.182

Faixa de vôo: 327D

Data: 09-08-73

e) Unidade Canfilito ( $\mathrm{Ca}-2)$

Fotografias: 50.181 a 50.184

Faixa de vôo: 327D

Data: 09-08-73

\section{1 .4 - Equipamentos}

Para a observação estereoscópica dos pares fotogräficos foram utilizados um estereoscópio de reflexão marca WILD, modelo ST-4, equipado com oculares para aumento de 3 vezes e um estereoscópio de bolso marca AIR PHOTO SUPPLY, mode10 PS-2. 
Nas medições do maior comprimento e da maior largura das bacias hidrográficas foi empregado um escalíme tro de precisão. As medições de comprimento dos rios.e perimetro das bacias foram efetuadas com o auxilio de um cur vỉmetro marca KENT, graduado em centímetros. Na determinação de āreas foi utilizado um planímetro polar marca KOIZU MI, mode1o KP-25.

\section{2 - Mētodos}

\subsection{1 - Seleção da ārea de estudo}

Os solos da região do rio Ribeira de Iguape, no Estado de São Pau1o, têm sido a1vo de intensos estudos nos últimos anos, no que diz respeito às suas propriedảes, classificação e distribuição geogräfica, com vistas à sua utilização de maneira mais racional.

Analisando-se a carta de solos da área, per cebe-se que a quadrícula correspondente à folha Pariqüera-Açu (SP), SG-23-V-A-IV-1, contëm representantes das.principais unidades de solo ocorrentes na região, com destaque para aquelas originadas dos sedimentos da Formação Pariqüe ra-Açu (LAa e PVLa-2) que, por suas características físicas e por estarem associadas a formas de relevo mais sua- 
61.

ves, apresentam grande importância para a agricultura regional.

Vem do exposto o fato de ter sido seleciona da para este estudo a área citada, compreendida entre os paralelos $23^{\circ} 45^{\prime} \mathrm{S}$ e $25^{\circ} 15^{\prime} \mathrm{S}$ e os meridianos $46^{\circ} 45^{\prime} \mathrm{W} \mathrm{Gr}$. e $49^{\circ} 30$ 'W Gr., com cinco unidades de solo de expressão regio nal (Pariqüera, Taquaruçu, Arataca, Vapamirim e Canfilito). De posse da carta de solos e do fotoíndice correspondente foi feita a identificação das fotografias que recobriam äreas representativas de cada uma das cinco unidades de solo.

\subsection{2 - Elaboração dos mapas básicos de drenagem}

Para cada uma das cinco unidades de solo foi elaborado um mapa básico parcial de drenagem. Para essa ela boração, a fotografia da direita de cada par estereoscōpico foi recoberta por uma folha de acetato transparente, re cortada nas mesmas dimensões da cōpia fotogräfica. Atravës de exame sob o estereoscópio de reflexão foram decalcados todos os canais de drenagem, permanentes e temporārios, no modelo estereoscópico, desde que fizessem parte funcional do sistema de drenagem, conforme procedimento adotado por FRANÇA (1968)。 
Além dos canais de drenagem foram também de calcadas as āreas de baixadas úmidas, indicadoras de rede pouco integrada, conforme LUEDER (1959) e os divisores de águas das bacias de terceira ordem, segundo o Sistema Americano modificado por STRAHLER (1957).

$\mathrm{Na}$ montagem do mapa, de cada folha de aceta to foi aproveitada apenas a sua porção mais central, por ser a que menores distorções radiais apresenta, em 'decorrência do sistema de projeção cônica, inerente às fotografias aéreas verticais. Essa porção central, tambëm conheci da por "ärea útil" da fotografia, pode ser melhor compreen dida pela observação da Figura 6 .

Para facilitar o ajuste entre os acetatos de duas fotografias consecutivas, foram decalcados alguns alvos (construções, trechos de estradas, etc.) comuns às duas imagens。

Os acetados jā decalcados também são conhecidos por templetos. Com fita adesiva os templetos foram devidamente montados e o produto dessa montagem foi recopiado em papel vegetal, resultando nos mapas básicos de dre nagem, um para cada unidade de solo. 


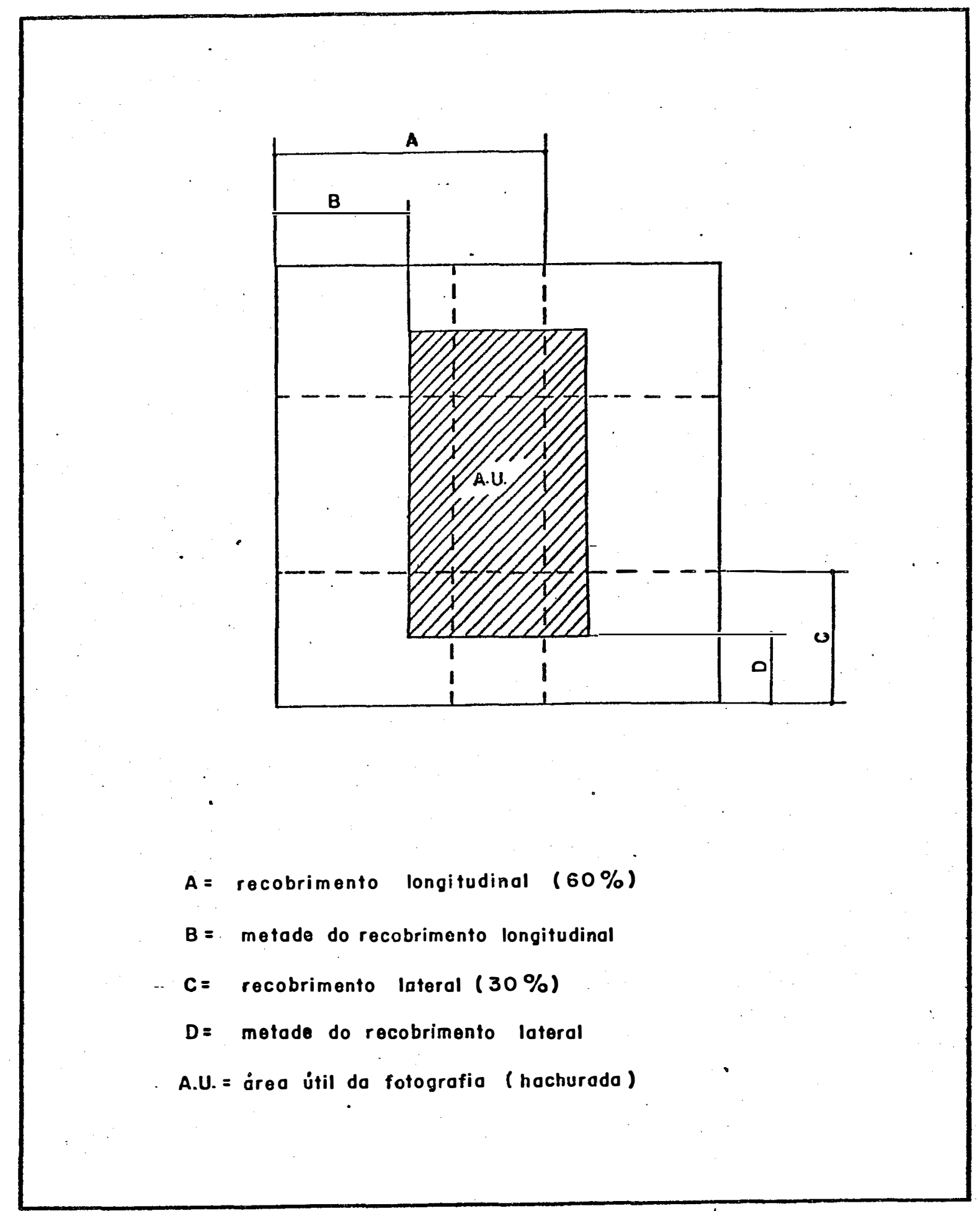

Figura 6 - Ârea útil em uma fotografia aërea vertical. 
Sobre os mapas básicos de drenagem foram traçados os limites entre as diferentes unidades de mapeamento e também numeradas todas as bacias hidrogräficas de ter ceira ordem, a fim de ordenā-las para as fases de seleção e anālise das mesmas.

\subsection{3 - Seleção das bacias hidrogräficas}

Para que se possam fazer comparações vālidas entre duas ou mais bacias hidrogrāficas, no caso da fo tointerpretação para levantamento de solos, è preciso que haja suficiente homogeneidade geológica e edafológica entre as amostras, ou seja, apresentem solos semelhantes (FROST, 1960). Esta condição foi obedecida delimitando-se

e trabalhando-se sobre a unidade principal de mapeamento em cada mapa bäsico de drenagem, orientando-se, na delimitação, pela carta de solos da região e pelos aspectos da pai sagem observāveis nas imagens fotogrāficas.

Outra condição obedecida na seleção das amostras foi a semelhança geométrica entre as bacias a serem comparadas (STRAHLER, 1957). Sendo as bacias geometricamente semelhantes, todas as medições feitas guardarão ra zões de escala aproximadamente constantes. 
Pelo exposto, nota-se que as questões relativas a homogeneidade, semelhança geométrica e representatividade das unidades amostrais são imprescindiveis no pro cesso de seleção das bacias a serem analisadas, dentro de uma mesma unidade de mapeamento.

Partindo-se do princípio que bacias hidrográficas representativas de uma dada unidade de solo são aquelas que aparecem em maior frequêencia, com caracteristí cas geomêtricas e funcionais (relativas à drenagem) semelhantes, foi estabelecido, neste trabalho, um critërio de seleção baseado justamente na mäxima semelhança entre um conjunto de vârios aspectos dimensionáveis das bacias. Para tanto foi feita uma anälise preliminar, com todas as ba cias de terceira ordem encontradas no mapa básico de drena gem de cada unidade de mapeamento. Nessa análise levou-se em conta os seguintes parâmetros de cada bacia hidrográfica: (a) maior comprimento; (b) maior largura; (c) perímetro; (d) årea; (e) comprimento do rio principal; (f) comprimento total da rede hidrogräfica; (g) nümero de rios de primeira ordem; e (h) comprimento total dos rios de prime ra ordem。

De acordo com os valores determinados, para cada parâmetro foi feita uma distribuição das bacias em classes de mesma amplitude $\left(0,1 \mathrm{~km}^{2}\right.$ para o parâmetro "área" 
e $0,1 \mathrm{~lm}$ para os demais, à exceção do número de rios de primeira ordem).

0 passo seguinte constituiu-se na pré-seleção das ba cias pertencentes à classe modàl de cada parâmetro, isto é, à classe com. o maior número de bacias (maior freqüência).

Organizou-se, então, uma tabela para cada unidade de mapeamento, onde cada bacia foi caracterizada com o valor da freqüência com que apareceu no conjunto dos oito parâmetros (portanto, a frequiência máxima possível era igual a oito).

Selecionou-se, por fim, para cada unidade de solo, três bacias com os maiores valores de freqüência, para se constituirem nas unidades amostrais. Em caso de igualdade no valor da freqüência, o desempate foi feito por meio de exame visual das bacias analisadas, observando-se características como tamanho, forma, simetria das vertentes, etc.

A utilização de três amostras para cada unidade de solo resultou de una análise preliminar, onde alguns indices foram calculados a partir de três, quatro e cinco amostras. Os resultados mostra ram não haver praticamente diferença no emprego dos três números de uni dades amostrais. Conseqüentemente, optou-se pelo menor número, contribuindo assim para a simplificação na estruturação do trabalho.

Para melhor elucidar a metodologia descrita, segue um exemplo hipotético do processo de seleção.

- Unidade de solo: unidade A

- Número de bacias de terceira ordem constatadas no mapa bāsico de drenagem: 10

- Número de bacias (amostras) a serem selecionadas: 3 
67.

A) Distribuição das bacias em classes de mesma amplitude, de acordo com os valores determinados para cada parâmetro :

A.1) Parāmetro "maior comprimento"

Menor valor encontrado $=0,321 \mathrm{~km}$ (bacia no 10)

Maior valor encontrado $=0,987 \mathrm{~km}$ (bacia $\mathrm{n}$ ? 3)

\begin{tabular}{cc}
\hline $\begin{array}{c}\text { CLASSES } \\
(\mathrm{km})\end{array}$ & $\begin{array}{c}\text { NOMERO DAS } \\
\text { BACIAS }\end{array}$ \\
\hline $0,300-0,400$ & 10 \\
$0,400-0,500$ & 4 \\
$0,500-0,600$ & 5 \\
$0,600-0,700$ & 8 \\
$0,700-0,800\left(^{*}\right)$ & $1,2,7,9\left(^{*}\right)$ \\
$0,800-0,900$ & 6 \\
$0,900-1,000$ & - \\
\hline
\end{tabular}

$(*)$ classe modal.

Esse mesmo tipo de distribuição ê feito para os demais parâmetros e, a seguir, selecionam-se apenas as bacias incluídas na classe modal para cada parâmetro.

B) Bacias prê-selecionadas para cada um dos parâmetros utilizados no processo de seleção: 
68.

\begin{tabular}{ll}
\hline \multicolumn{1}{c}{ PARAMMTROS } & $\begin{array}{c}\text { BACIAS PRE- } \\
\text {-SELECIONADAS }\end{array}$ \\
\hline Maior comprimento & $1,2,7,9$ \\
Maior largura & $1,3,5$ \\
Perímetro & $1,4,6,8$ \\
Area & $1,2,9$ \\
Comprimento do rio principal & $2,3,4$ \\
Comprimento total da rede & $1,8,9,10$ \\
Nümero de rios de 1 a ordem & $2,3,5$ \\
Comprimento total dos rios de 1 a ordem & $1,2,9$ \\
\hline
\end{tabular}

C) Frequêencia atingida pelas bacias, no conjunto dos oi to parâmetros utilizados no processo de seleção:.

\begin{tabular}{ccccccccccc}
\hline BAC IAS & 1 & 2 & 3 & 4 & 5 & 6 & 7 & 8 & 9 & 10 \\
\hline Freqüência (mäx.=8) & 6 & 5 & 3 & 2 & 2 & 1 & 1 & 2 & 4 & 1 \\
\hline
\end{tabular}

D) Bacias selecionadas pelos maiores valores de freqüên cia, em ordem decrescente: 
69.

\begin{tabular}{cc}
\hline BACIAS & FREQÜENCIA \\
\hline 1 & 6 \\
2 & 5 \\
9 & 4 \\
\hline
\end{tabular}

Portanto, para a unidade $A$, as três bacias hidrogräficas selecionadas para se constituirem em unidades amostrais são as de números 1,2 e 9 .

\subsection{4 - Anälise das bacias hidrogräficas}

\subsubsection{1 - Propriedades dimensionais}

a) Maior comprimento (MC): medido com escala, acompanhan do aproximadamente a direção do vale principal, entre a foz e o ponto extremo sobre a linha do divisor de águas. É expresso em quilômetros;

b) Maior largura (ML): medida com escala, transversalmente à linha do maior comprimento, no ponto em que os divisores de āguas estão mais afastados. É expressa em quilô metros;

c) Perimetro (P): è a medida do comprimento do divisor de águas da bacia considerada. Determinado com curvímetro e expresso em quilômetros; 
d) Area (A): è a medida, em planta, da superfície da bacia. Determinada com planímetro e expressa em quilômetros quadrados;

e) Comprimento do rio principal (CRP): è o comprimento do canal de drenagem de ordem mais elevada da bacia (no caso terceira ordem), medido desde a sua foz até a nascente, com um curvímetro. Seu trajeto foi determinado adotando-se procedimento proposto por HORTON (1945), ou seja: prolongando-se o rio principal para montante, nas bifurcações o seu percurso corresponde ao ramo que formar o menor ângulo de junção. Em ca so de empate no primeiro critério, a escotha recai sobre o ramo que apresenta o maior comprimento. Ex expresso em quilômetros;

f) Comprimento total da rede (Lt): o comprimento total da rede representa a somatória dos comprimentos de todos os segmentos de rios. E medido por meio de curvímetro e expres so em quilômetros.

\subsubsection{2 - Propriedades não dimensionais}

a) Forma aproximada: associa-se a forma superficial da bacia hidrogräfica a figuras geométricas e dâ-se a meșma a denominação da figura que dela mais se aproximar. Com isso podemos ter bacias ovais, triangulares, trapezoidais, etc.; 
b) Ordem de ramificação (STRAHLER, 1957): no presente trabalho foram utilizadas bacias hidrográficas de terceira ordem de ramificação, conforme sugestão de FRANÇA (1968), para o estudo de solos;

c) Simetria das vertentes: indicada pelo declive das en costas em relação ao vale principal e pela disposição dos tributārios.

3.2.4.3 - Teste de semelhança geométrica

Seguindo os princípios propostos por STRAHLER (1957), a semelhança geomëtrica foi testada para cada grupo de três bacias representativas de cada unidade de ma peamento. Esse teste de semelhança geomëtrica, entre bacias de mesma ordem, foi usado para dar maior segurança às comparações feitas e maior consistência aos resultados.

Empregou-se a "Razão de Equivalência", Re = $=(\mathrm{Rm})^{2} / \mathrm{r}$, proposta por MANECHINI (1981), para testar a semelhança geométrica entre as bacias, comparadas duas a duas. A semelhança entre as bacias de um par comparado é tanto maior, quanto mais próximo da unidade estiver o valor de Re.

As relações empregadas, entre as bacias com paradas, foram as seguintes: 
72.

Maior comprimento bacia a

Maior comprimento bacia b

Maior largura bacia $\mathrm{a}=\ell$

Maior largura bacia b

$\underline{\text { Perimetro bacia } \mathrm{a}}=\mathrm{p}$

Perímetro bacia $b$

$\frac{\text { Comprimento rio principal bacia } \mathrm{a}}{\text { Comprimento rio principal bacia } \mathrm{b}}=\mathrm{cp}$

Comprimento total da rede bacia $\mathrm{a}=\mathrm{cr}$

Comprimento total da rede bacia b

$c+\ell+\frac{p+c p+c r}{5}=R m$ (razāo média)

$\frac{\text { Area bacia } a}{\text {. }}=r$

$\overline{\text { Área bacia } b}$

$$
\operatorname{Re}=\frac{(\mathrm{Rm})^{2}}{\mathrm{r}}
$$

3.2.5 - Análise das redes de drenagem

Para a análise das redes de drenagem utilizou-se o "mëtodo de análise de elementos", proposto por $\underline{B U}$ RINGH (1960). De acordo com a sua natureza, os elementos analisados podem pertencer āqueles referentes à composição 
da rede de drenagem, ou àqueles referentes ao padrão de dre nagem •

3.2.5.1 - Composição da rede de drenagem

a) Ordem de ramificação: os segmentos de rios, ou canais de drenagem, foram classificados quanto à ordem de ra mificação tomando-se por base o sistema de HORTON (1945) modificado por STRAHLER (1957). A designação geral para or dem è a letra w;

b) Nümero de segmentos de rios: foram computados os nú meros de segmentos de rios em cada ordem, designados por $\mathrm{Nw}$ e o total de cada bacia, designado por $\mathrm{Nt}$;

c) Comprimento dos segmentos de rios: usando-se o'cur vímetro, foi medido o comprimento total dos segmentos de rios para cada ordem de ramificação e, a seguir, calculados os seus comprimentos mẻdios atravês da relação "comprí mento total/número de segmentos de rios". As designações utilizadas foram: Lw e Lwm, respectivamente, para comprimento total e comprimento mëdio. 

3.2.5.2 - Características do padrão de dre nagem

0 padrão de drenagem foi analisado através de suas características descritivas e quantitativas.

A) Caracteristicas descritivas

Como caracteristicas fundamentais foram ado tadas aquelas sugeridas por LUEDER (1959), acrescidas do "tipo ou modelo" (PARVIS, 1950).

a) Grau de integração: é a maior ou menor definição do percurso dos canais. Quanto mais evidente e mais curto, maior è a integração. o padrão de drenagem pode ser classí ficado em: não integrado (os canais näo se ligam); pouco integrado (poucos canais se 1igam); integrado (todos se $1 \underline{\mathbf{i}}$ gam); e bem integrado (todos se ligam, pelas distâncias mais curtas);

b) Densidade: indica o número relativo de canais por unidade de ärea. Pode ser classificada em: baixa, mëdia e a1ta;

c) Grau de uniformidade: indica a repetição de formas num determinado espaço. o padrão de drenagem pode ser classificado, quanto ao grau de uniformidade em: não uniforme, pouco uniforme e uniforme; 
d) Orientação: diz respeito a aspectos direcionais, tais como a predominância de direção dos canais. o padrão de drenagem, quanto à orientação, pode ser classificado em: não orientado, pouco orientado e fortemente orientado;

e) Angularidade: é a mudança brusca de direçāo dos cạ nais em vales encaixados. Pode ser classificada em: baixa, média e alta;

f) Grau de controle: é funçāo dos fatores que alteram - sentido geral da drenagem, tais como orientação e angula ridade. Quanto ao grau de controle o padrão de drenagem po de ser classificado em: não controlado, controlado e altamente controlado;

g) Ângulos de junção: são os ängulos formados na confluência de um tributârio com seu receptor. Podem ser classificados em: retos, agudos e obtusos;

h) Tipo ou mode1o: refere-se à semelhança entre o esquema em planta dos rios de uma bacia e objetos ou conceitos geométricos, tais como: modelo dendritico ou arborescente, paralelo, retangular, etc. 
76.

\section{B) Caracteristicas quantitativas}

A partir dos dados determinados sobre as ba cias hidrogräficas, foram calculados os seguintes indices de drenagem:

a) Densidade de drenagem (Dd): fornece a extensão da rede de drenagem por unidade de ārea (HORTON, 1945) e é ex pressa em quilômetros por quilômetro quadrado;

b) Freqüēncia de rios (F): expressa o nümero de rios por unidade de ârea;

c) Comprimento mëdio dos canais de drenagem superficial $(\mathrm{Lm})$ : expressa a relação entre o comprimento total e o número de canais de drenagem da bacia hidrogräfica. Dife re dos outros indices estudados por apresentar, segundo CHRISTOFOLETTI e CÉSAR (1978), uma correlação inversa, isto é, aumentando com a diminuição do número de canais. 0 comprimento médio dos canais de drenagem foi adaptado por FRANCA (1968) para o estudo de solos, a partir da proposição original de RAY e FISCHER (1960) para estudos geológi $\cos$;

d) Razão de textura (T): è a relação entre o número total de rios e o perímetro da bacia, segundo a förmula de SMETH (1950), modificada por FRANCA (1968); 
e) Razão de textura mëdia (Tm): representa o valor mê dio ponderado da razão de textura em relação às āreas das bacias (SMITH, 1950), sendo representativo das unidades de solo. Este valor foi obtido aplicando-se a fórmula:

$$
\mathrm{Tm}=\frac{\sum(\mathrm{A} \cdot \mathrm{T})}{\Sigma \mathrm{A}},
$$

onde A representa a ārea e $\mathrm{T}$ a razão de textura de cada ba cia hidrogräfica;

f) Classe de textura topogräfica: determinada conforme adaptação de FRANÇA (1968) da classificação de SMITH (1950), ao sistema métrico. Este indice tem a finalidade de expressar o espaçamento entre os canais de drenagem.

\subsection{6 - Anålise estatística \\ 3.2.6.1 - Teste de Kruska1-Wa1lis}

Foi utilizado neste trabalho o teste não-pa ramétrico de Kruska1-Wa11is que, segundo CAMPOS (1979), constitui-se em um competidor ou substituto do teste $\mathrm{F}$ do campo paramétrico, tendo por finalidade averiguar se $\mathrm{k}$ amostras independentes provêm de uma mesma população, de po pulações semelhantes ou ainda de populaçōes distintas.

Admitindo-se $\mathrm{K}$ tratamentos, o teste permite averiguar se há diferença entre pelo menos dois deles, ou. 
78 .

seja, testar as seguintes hipöteses:

$$
\begin{aligned}
& H_{0}: t_{1}=t_{2}=\ldots=t_{k} ; \\
& H_{a}: \text { pelo menos dois tratamentos diferem entre si. }
\end{aligned}
$$

As pressuposições desse teste são:

- as $\underline{\mathrm{n}}$ observações são todas independentes;

- dentro de uma dada amostra, todas as observações são provenientes de uma mesma população;

- as populações são aproximadamente da mesma forma e continuas.

No presente trabalho, os tratamentos testados foram as caracteristicas relativas à rede de drenagem de cinco unidades de solo ocorrentes na área de estudo. Conven cionou-se denominar esses tratamentos por $\mathrm{S}_{1}, \mathrm{~S}_{2}, \mathrm{~S}_{\mathrm{e}}, \mathrm{S}_{4}$ e $\mathrm{S}_{5}$, correspondendo às unidades Pariqüera, Taquaruçu, Arataca, Vapamirim e Canfilito, respectivamente, para as caracte rísticas medidas em bacias hidrográficas de terceira ordem.

Para cada característica procedeu-se à classificação conjunta das $N=\sum_{i=1}^{k} n_{i}$ observações, dando ordem 1 à menor delas e ordem $\mathrm{N}$ à maior. Nos casos onde 'ocorreram empates entre duas ou mais observações, o desempate foi feito considerando-se a média das ordens. 
79.

Em seguida, para a aplicação do teste, calculou-se a estatística:

$$
H=\frac{12}{N(N+1)} \sum_{i=1}^{k} \frac{R_{i}^{2}}{n_{i}}-3(N+1),
$$

onde :

$R_{i}$ é a soma das ordens atribuídas ao tratamento $\underline{i ;}$ e $\mathrm{n}_{\mathbf{i}}$ è o número de observações para o tratamento $\underline{\mathbf{i}}$.

Para se testar, ao nível a de probabilidade, $\mathrm{H}_{\mathrm{o}}$ versus $\mathrm{H}_{\mathrm{a}}$, rejeita-se $\mathrm{H}_{\mathrm{o}}$ se $\mathrm{H}>\mathrm{h}$, onde.

$$
P_{0}(H \geq h)=\alpha
$$

( $\alpha$ e h são obtidos na Tabela 14, em CAMPOS, 1979, pág. 318).

$$
\text { No caso de empates obtêm-se }
$$

$$
\mathrm{H}_{1}=\frac{\mathrm{H}}{\mathrm{C}}
$$

onde:

$$
\begin{aligned}
C & =1-\frac{\sum_{i}^{g} T_{i}}{N^{3}-N} ; \\
g & =\text { nümero de grupos de empate; } \\
T_{i} & =t_{i}^{3}-t_{i} ; \\
t_{i} & =\text { número de observações empatadas no grupo } \underline{i} .
\end{aligned}
$$


80.

\subsubsection{2 - Comparações mū1tiplas}

As comparações mūitiplas foram empregadas co mo uma complementação do teste de Kruska1-Wa1lis, onde foi considerada a hipötese $H_{0}: t_{1}=t_{2}=\ldots=t_{k}$.

Quando $H_{0} \vec{e}$ rejeitada, admite-se que, pelo menos dois tratamentos diferem entre si. Assim, a finalidade das comparações múltiplas é localizar, quando existem, as diferenças significativas entre pares de tratamentos. No caso deste trabalho, as comparações envol veram todos os pares de tratamentos, com igual número de re petições entre os $k$ tratamentos, assim, para cada par i e j de tratamentos, foi determinada a diferença:

$$
\left|R_{i}-R_{j}\right| \quad \begin{aligned}
& (i=1,2, \ldots, k-1) \\
& (j=i+1, \ldots, k)
\end{aligned}
$$

onde $R_{i}$ e $R_{j}$ representam as somas das ordens atribuidas aos tratamentos $i$ e $j$ respectivamente, na classificação conjunta das $N$ observações referentes aos $k$ tratamentos. Se houver empates, são utilizadas as ordens mëdias.

A diferença minima significativa (d.m.s.) a uma "taxa de erro experimental" $\alpha$, segundo a qual admite-se $t_{i} \neq t_{j}$ é:

$$
\text { d.m.s. }=\Delta
$$


81.

$$
P_{0}\left(\left|R_{i}-R_{j}\right| \geq \Delta\right)=\alpha \text {. }
$$

Os valores de $\Delta$ são obtidos na Tabela 16 ,em CAMPOS, 1979 , pāg. 326 . 
82.

\section{RESULTADOS}

Os resultados obtidos neste estudo, referen tes às características das bacias hidrográficas e respectí vas redes de drenagem, são apresentados a seguir.

\section{1 - Mapas Bāsicos de Drenagem}

Os mapas bāsicos de drenagem, para as cinco unidades de solo estudadas, estão representados nas Figuras 7 a 11 . 


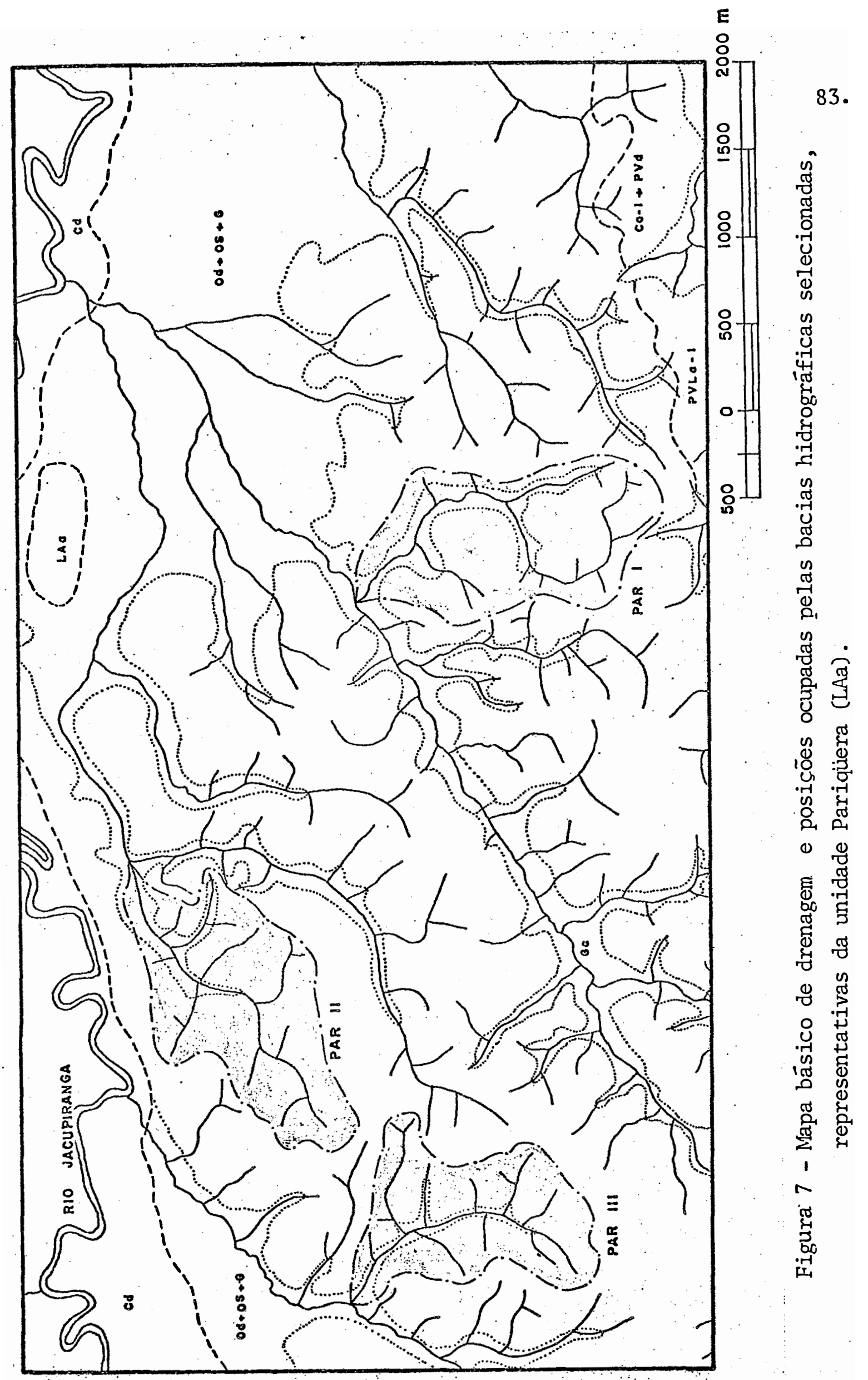




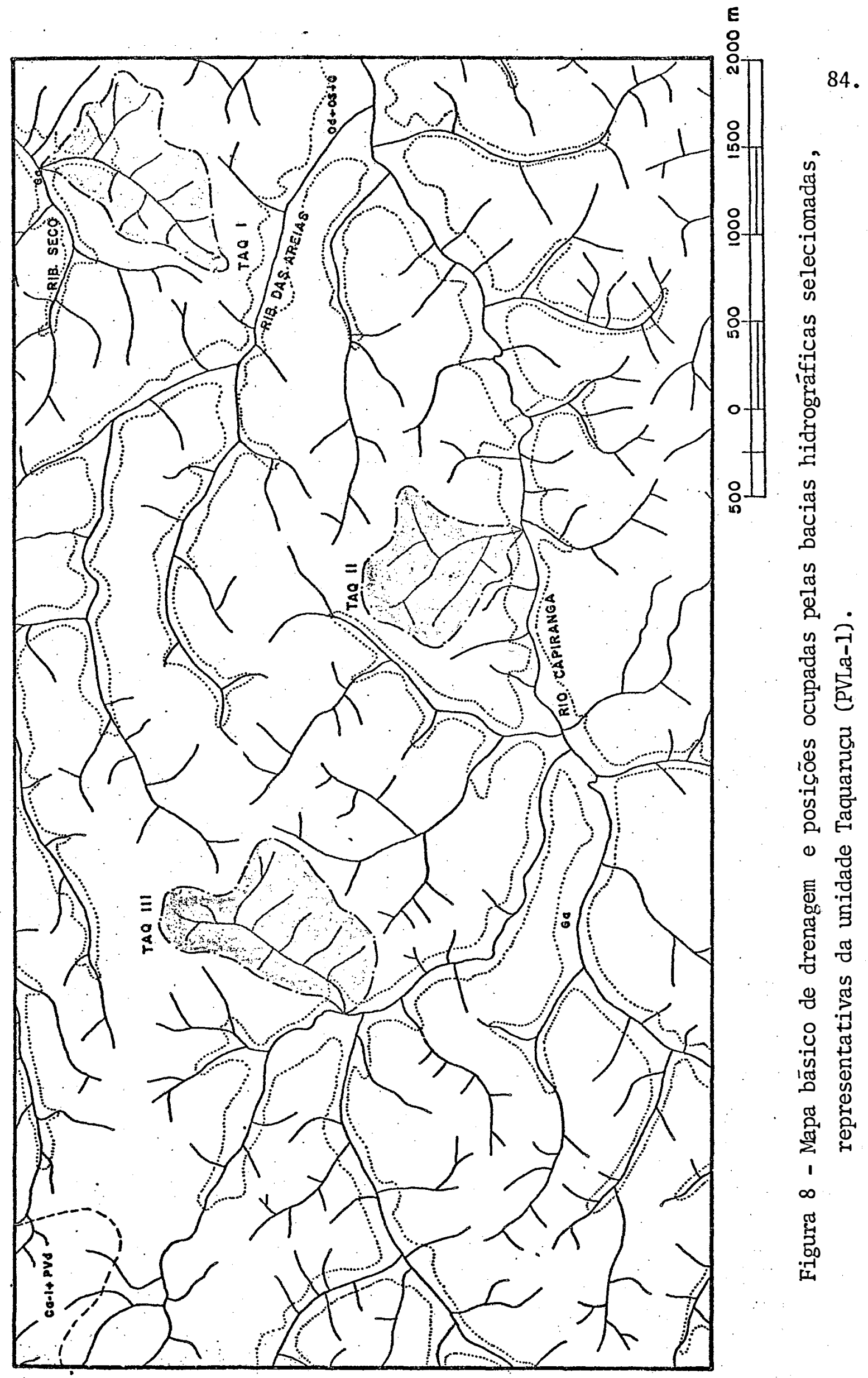




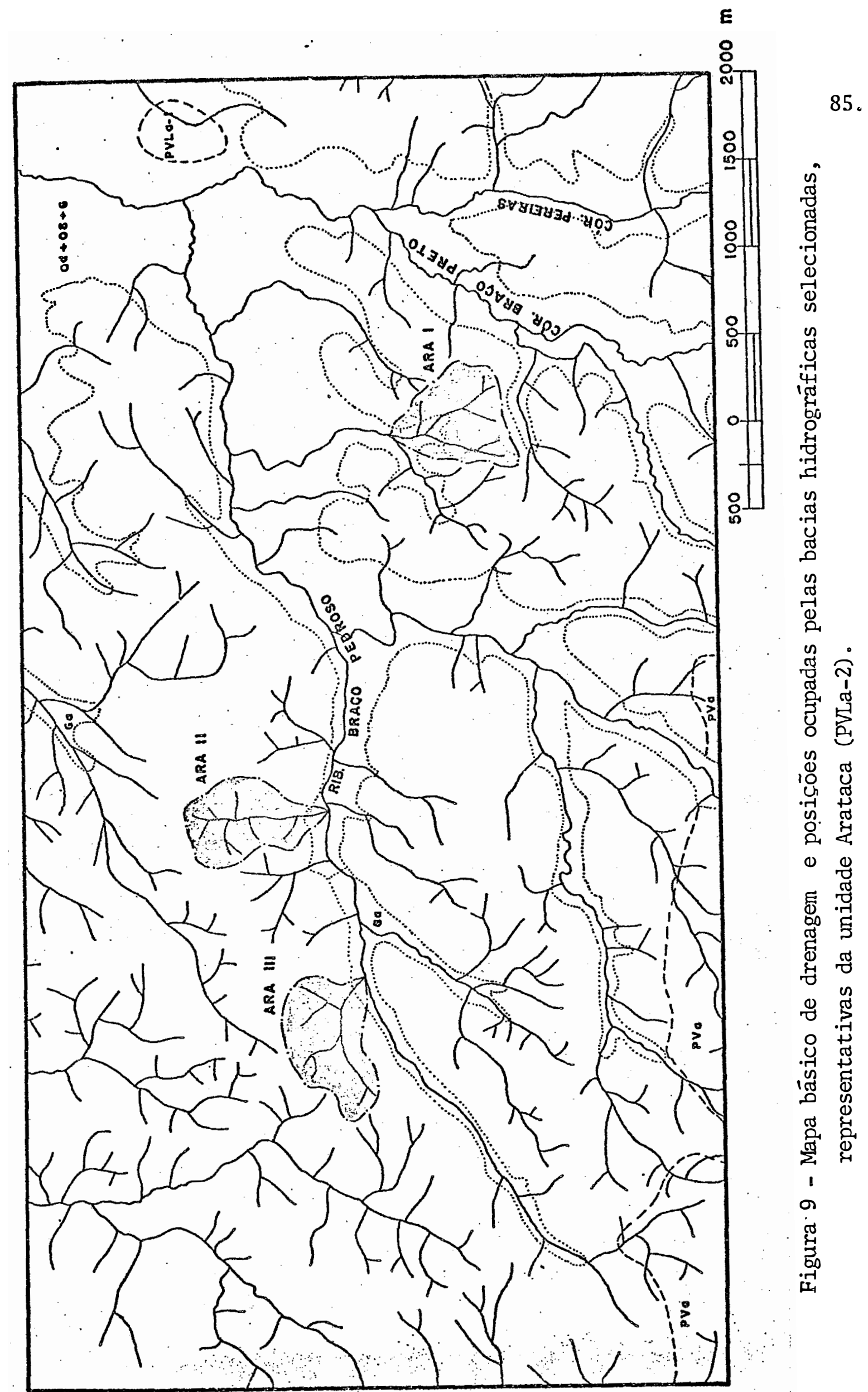




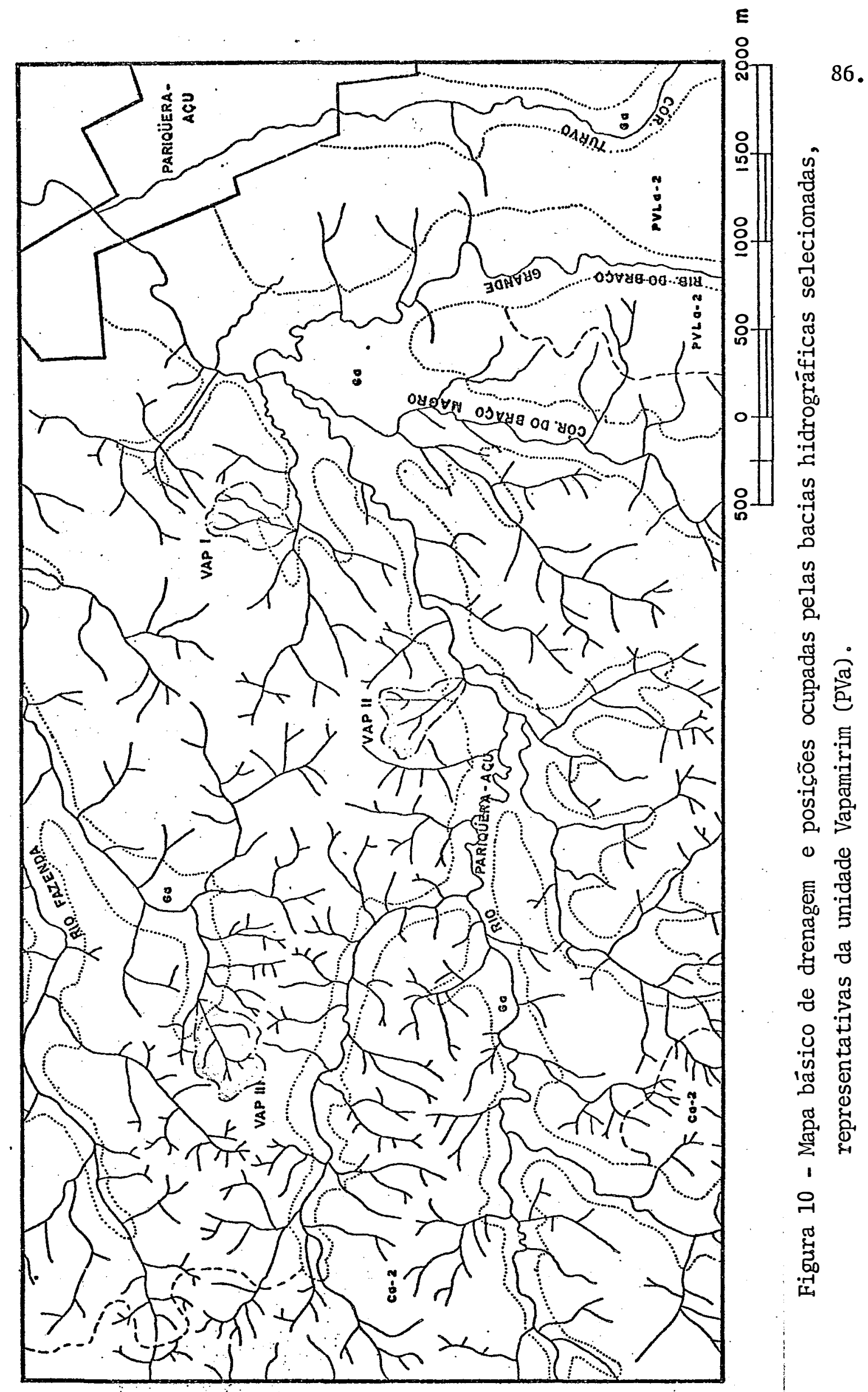




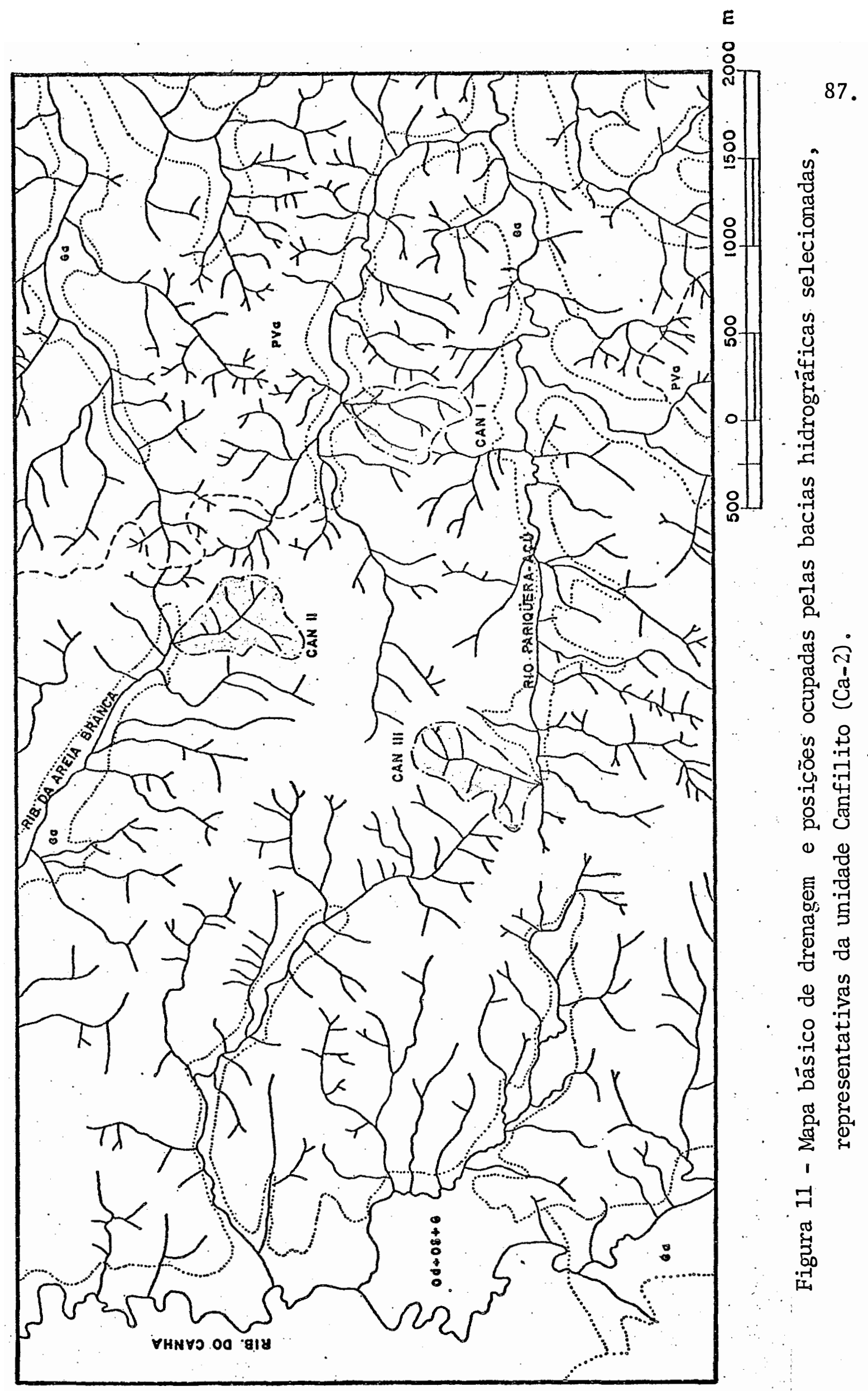




\section{2 - Seleçã̃o das Bacias Hidrogräficas}

De cada unidade de solo foram selecionadas, para estudos, três amostras (bacias hidrogräficas de terce $\underline{i}$ ra ordem) designadas por: PAR I, PAR II e PAR III (unidade Pariqüera); TAQ I, TAQ II e TAQ III (unidade Taquaruçu); ARA I; ARA II, ARA III (unidade Arataca); VAP I, VAP II e VAP II (unidade Vapamirim); e CAN I, CAN II e CAN III (unidade Canfilito) .

As posições ocupadas pelas bacias seleciona das são mostradas nos mapas básicos de drenagem (Figuras 7 a 11). Nas Figuras 12 a 16 estão representadas graficamente as bacias selecionadas para cada uma das unidades de solo.

No Apêndice deste trabalho, encontram-se $\underline{\text { re }}$ presentadas graficamente as bacias hidrográficas não selecionadas para se constituirem em unidades amostrais, juntamente com os valores dos parâmetros utilizados no processo de seleção. 

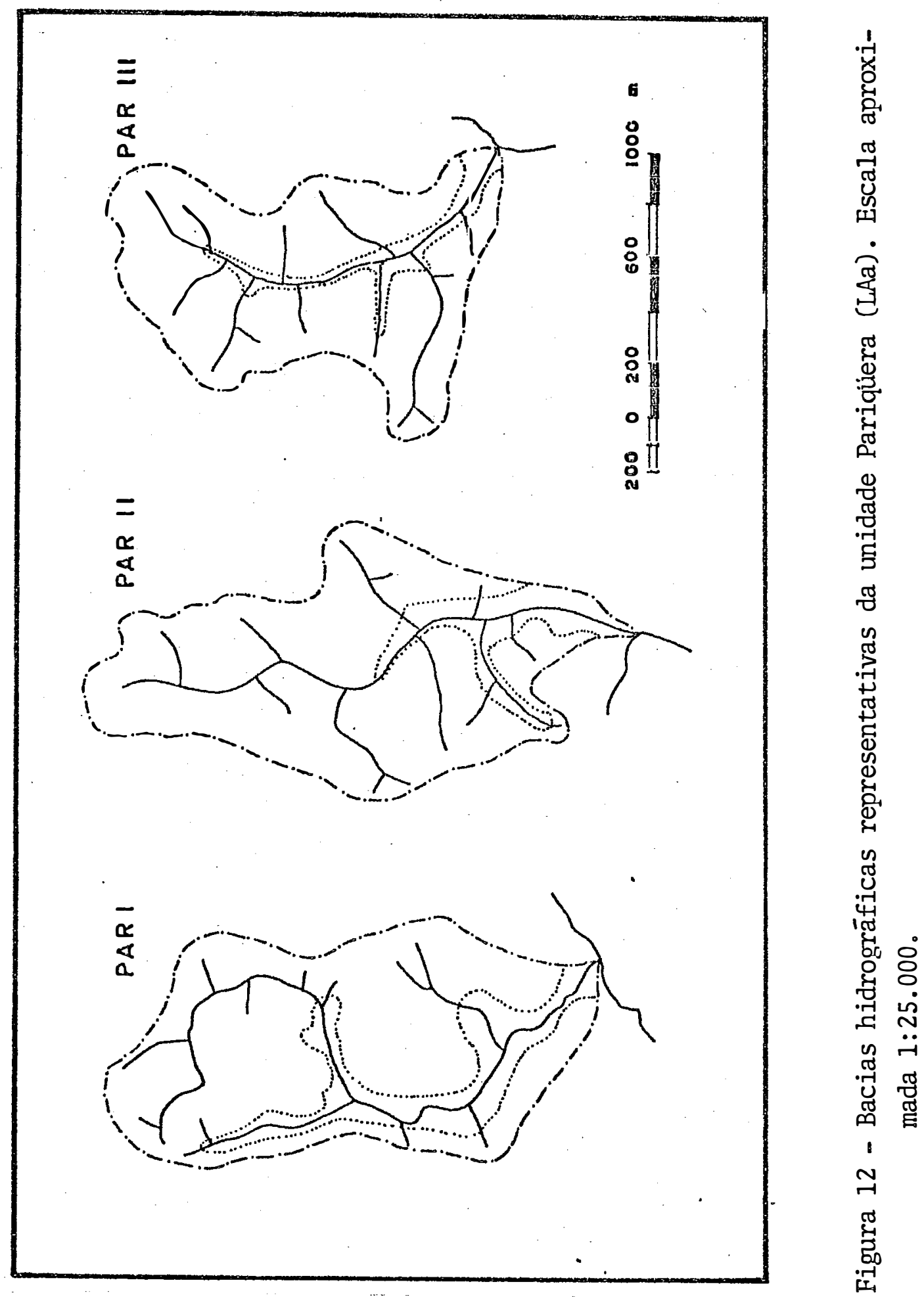

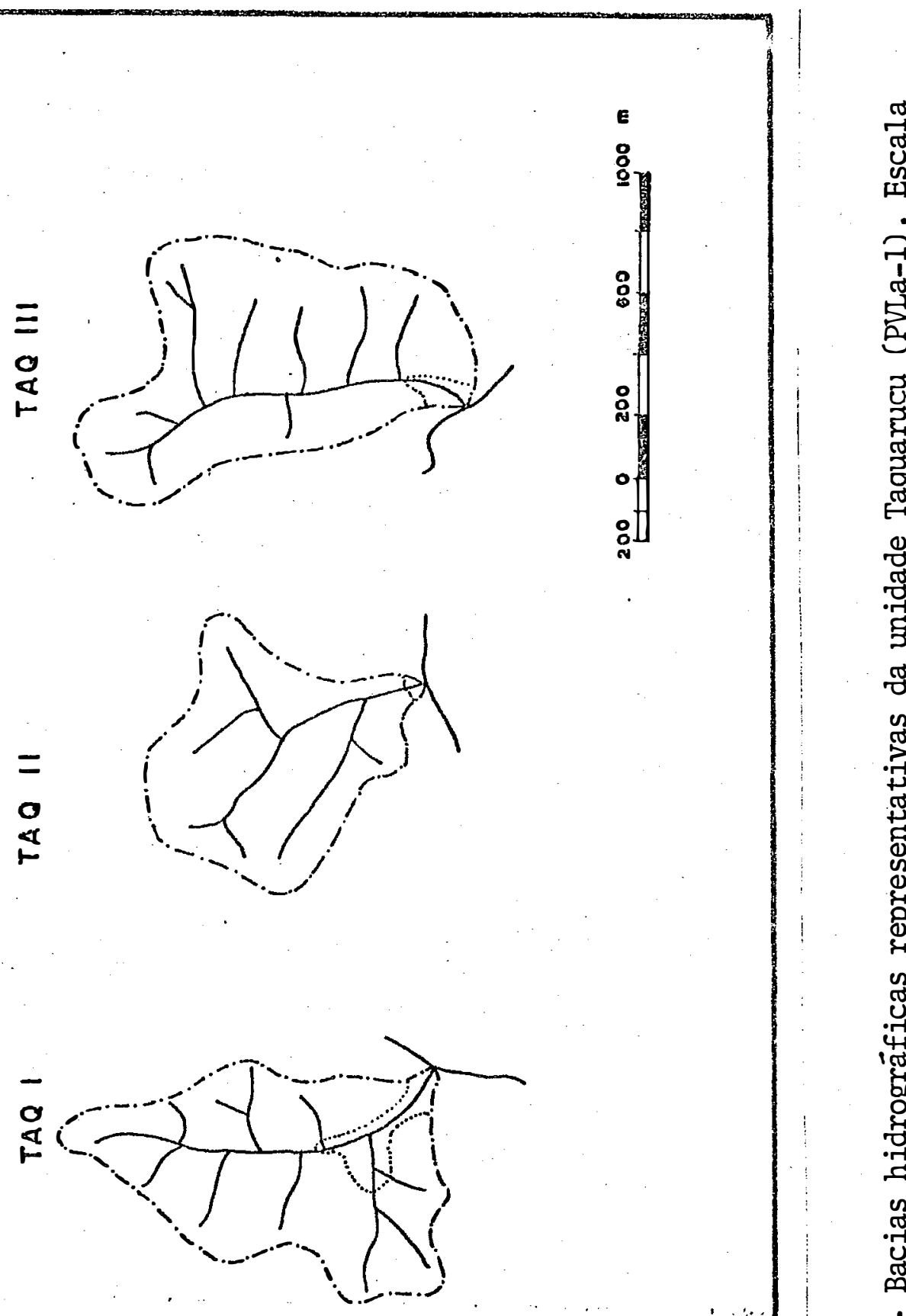
91.

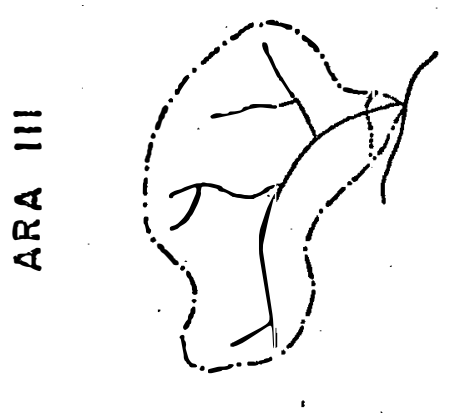

E

\section{:}

:

苈
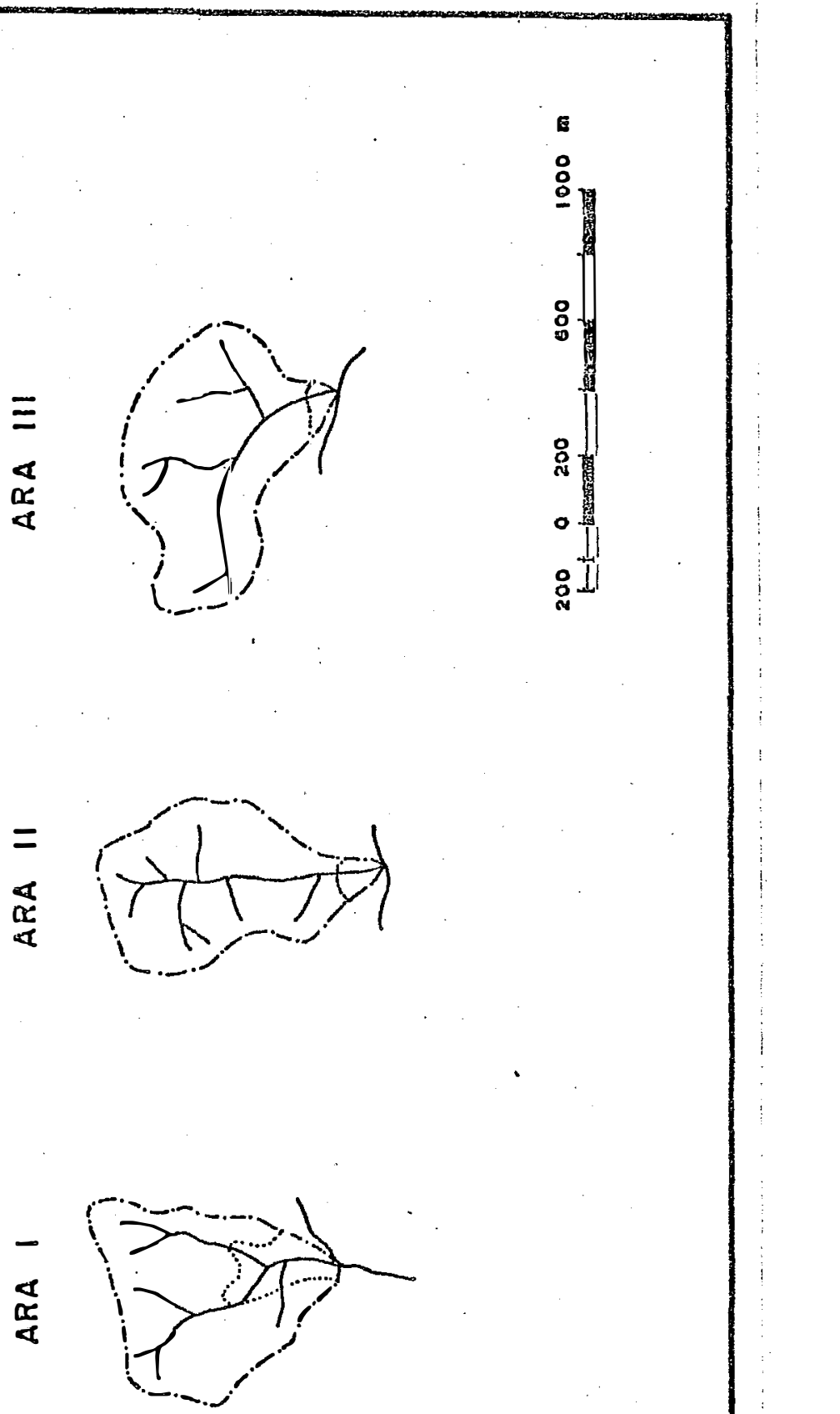


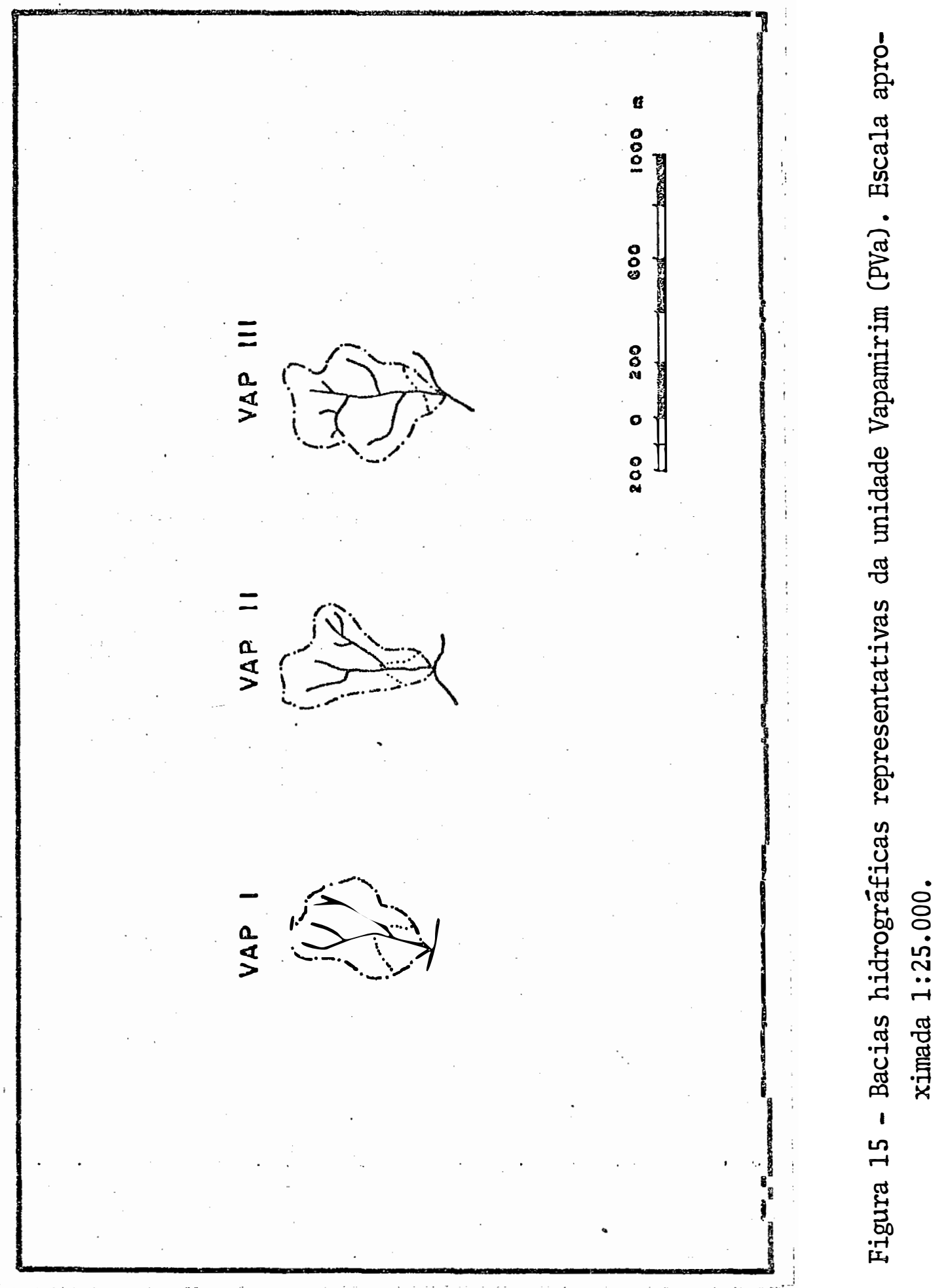


93.
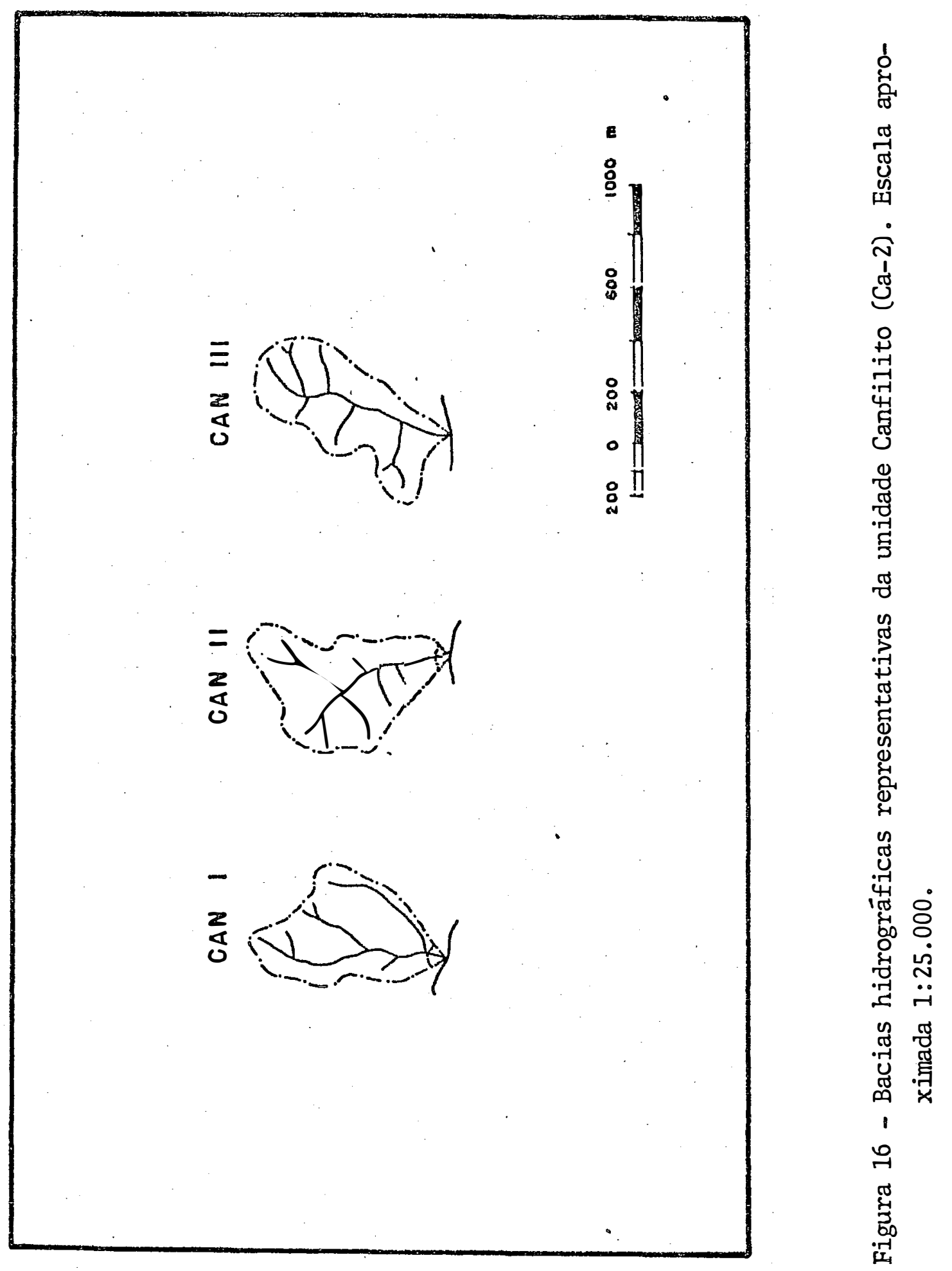
94.

4.3 - Anālise das Bacias Hidrogrāficas

4.3.1 - Propriedades dimensionais

As propriedades dimensionais determinadas nas bacias hidrográficas em estudo, médias e respectivos ex ros padrões são apresentados na Tabela 12 .

A anālise estatística desses dados encontra-se na Tabela 13.

\subsection{2 - Propriedades não dimensionais}

Na Tabela 14 são apresentadas as propriedades não dimensionais, forma aproximada e simetria das vertentes, das bacias hidrogräficas em estudo.

4.3.3 - Teste de seme1hança geomêtrica

$\mathrm{Na}$ Tabela 15 são apresentados os resultados referentes à análise dimensional e teste de semelhança geo mètrica, aplicados às bacias selecionadas para estudo. 


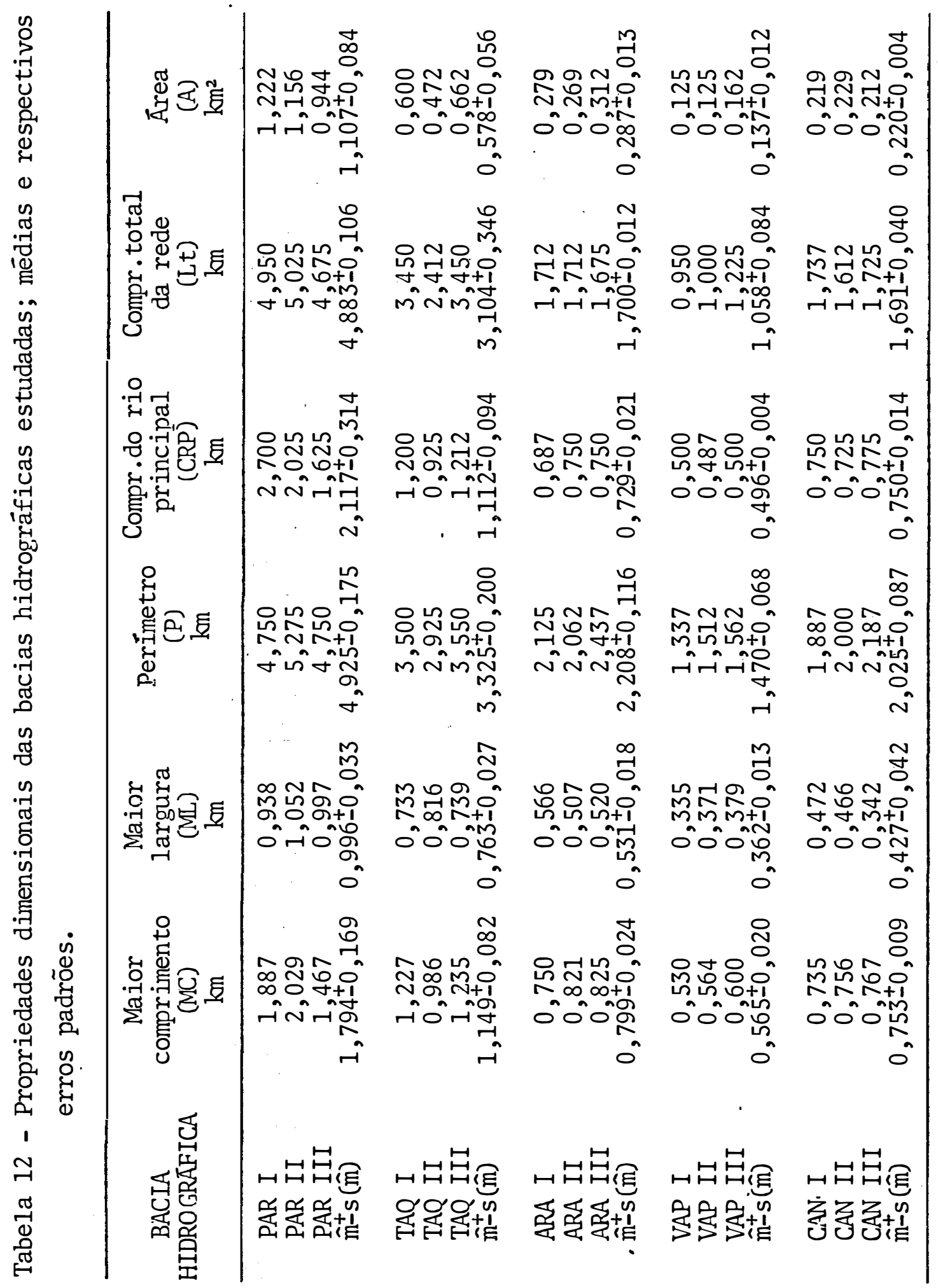


96.

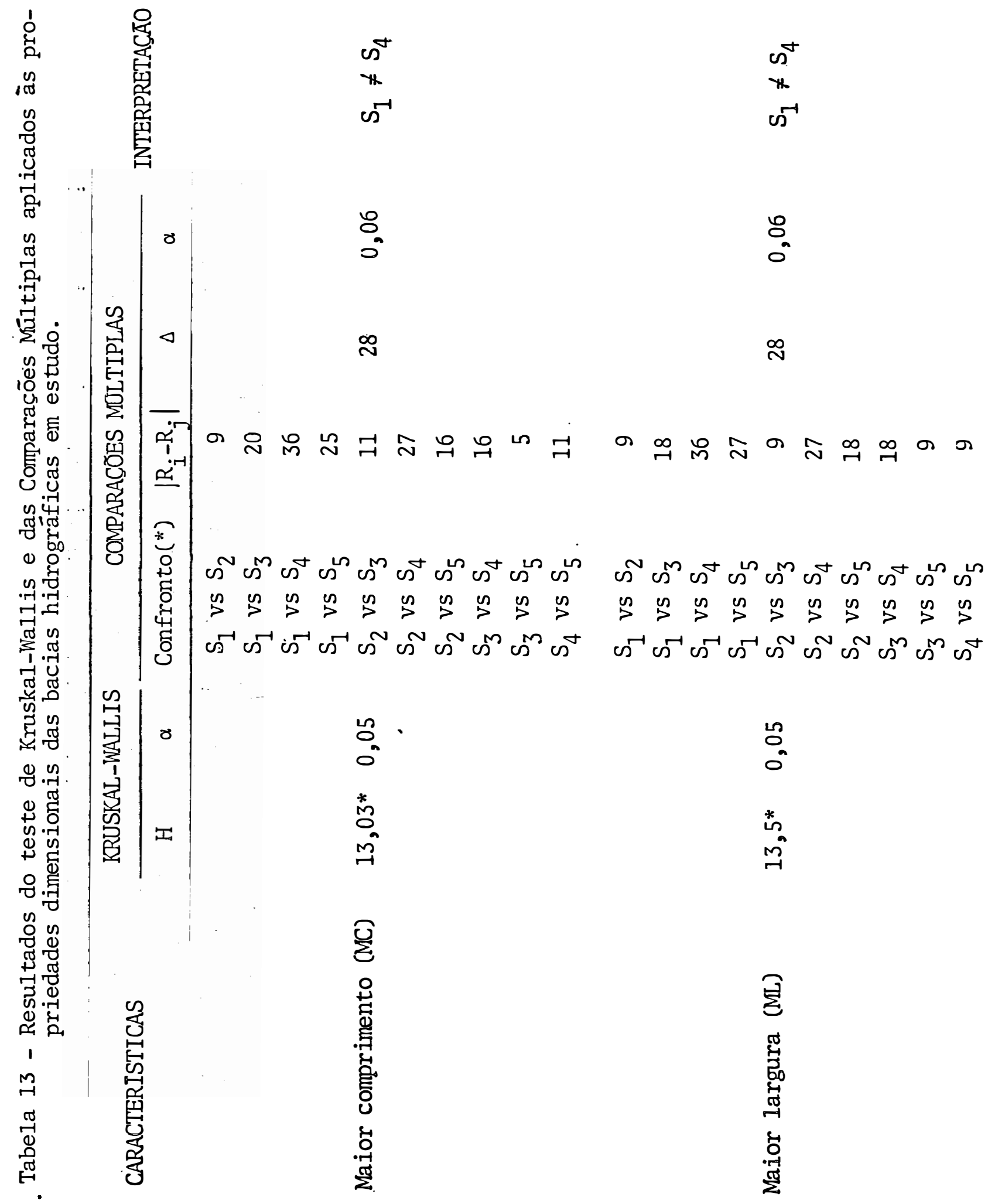


97.

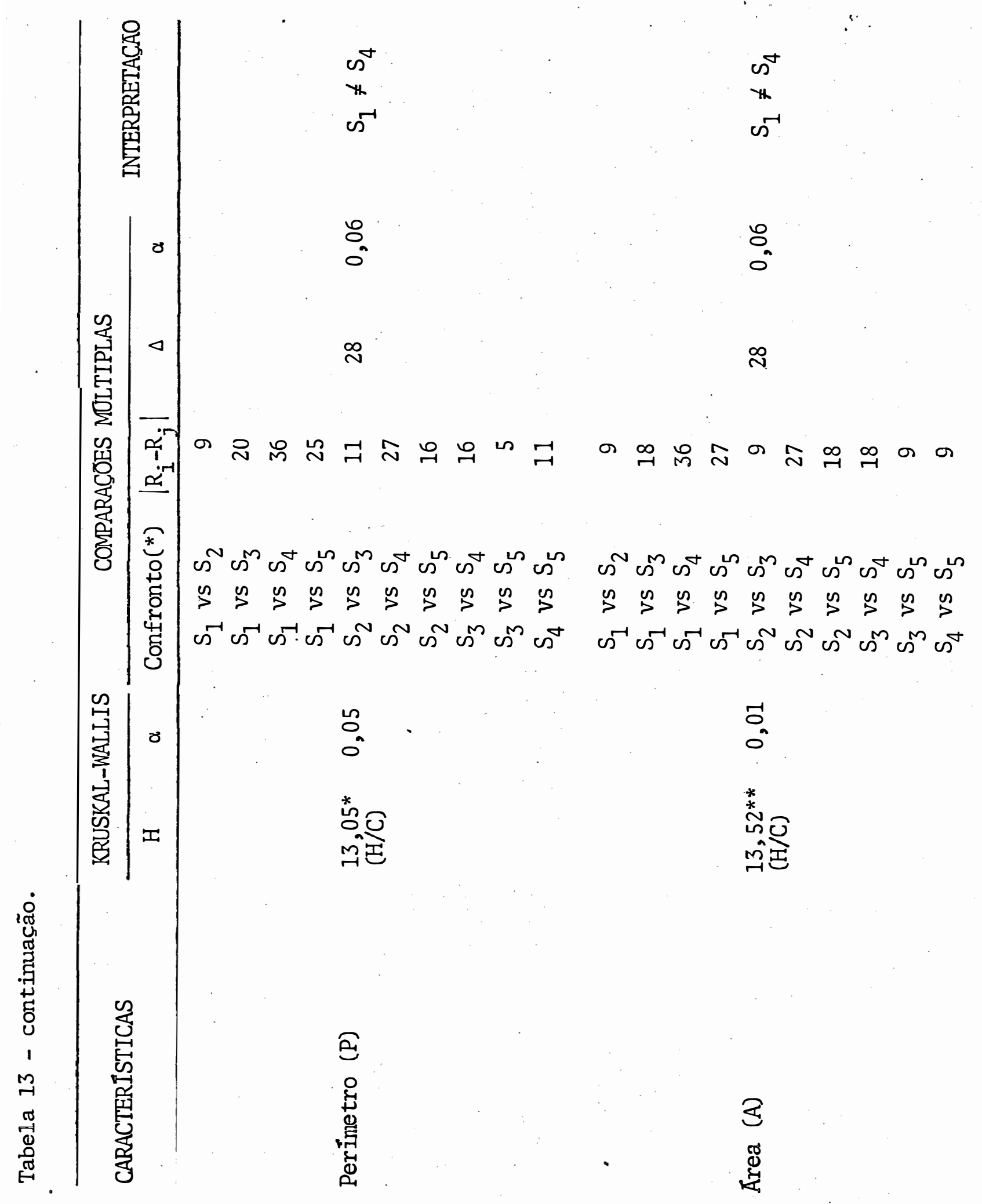




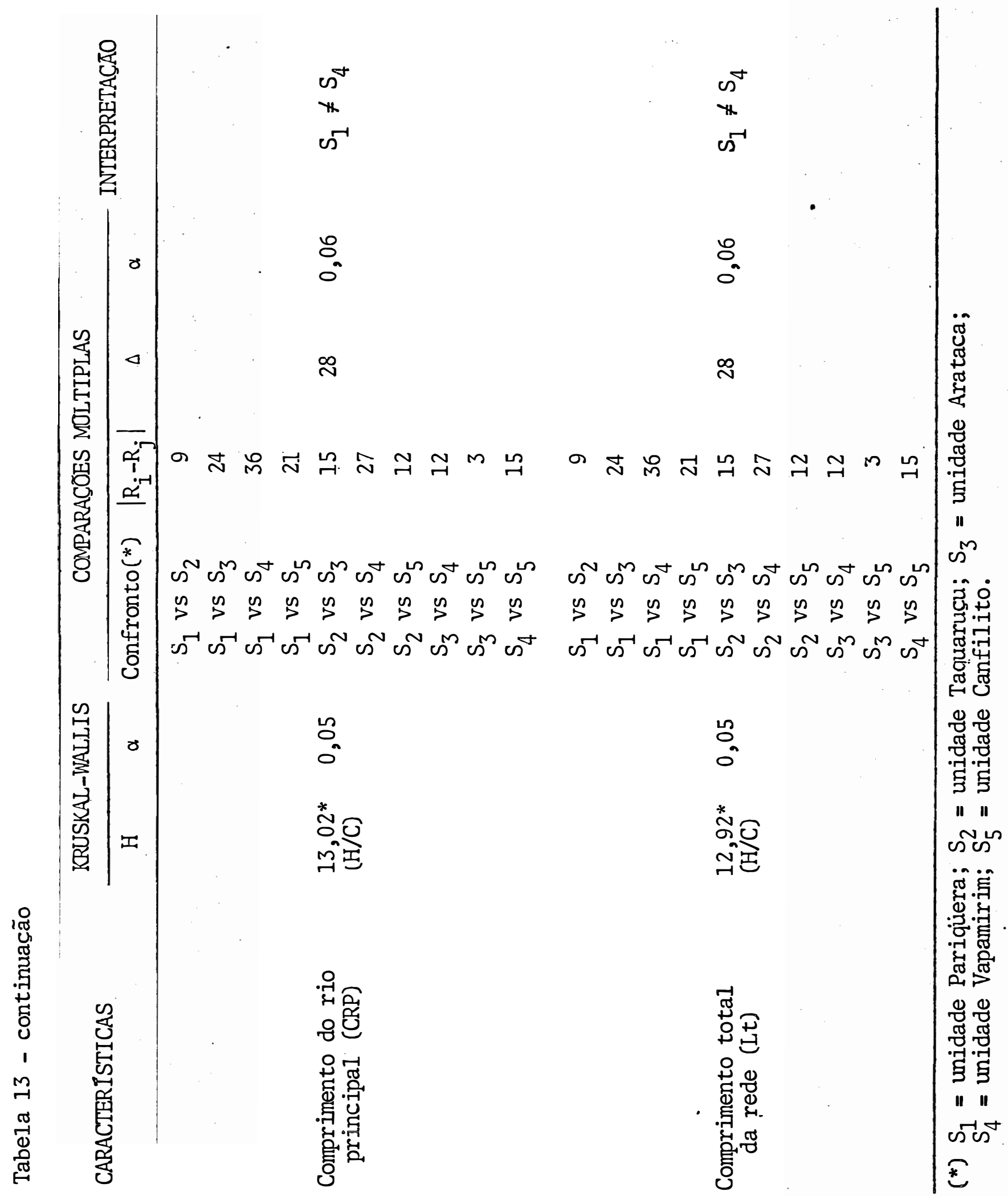


Tabela 14 - Propriedades não dimensionais das bacias hidrogräficas representativas das unidades de solo em estudo.

\begin{tabular}{|c|c|c|}
\hline BACIA HIDRO GRAFICA & FORMA APRO XIMADA & $\begin{array}{l}\text { SIMETRIA DAS } \\
\text { VERTENTES }\end{array}$ \\
\hline $\begin{array}{l}\text { PAR I } \\
\text { PAR II } \\
\text { PAR III }\end{array}$ & $\begin{array}{l}\text { paralelogramo } \\
\text { losangular } \\
\text { trapézoidal }\end{array}$ & $\begin{array}{l}\text { assimëtrica.. } \\
\text { pouco simëtrica } \\
\text { assimëtrica }\end{array}$ \\
\hline $\begin{array}{l}\text { TAQ I } \\
\text { TAQ II } \\
\text { TAQ III }\end{array}$ & $\begin{array}{l}\text { triangular } \\
\text { trapezoidal } \\
\text { trapezoidal }\end{array}$ & $\begin{array}{l}\text { assimētrica } \\
\text { assimêtrica } \\
\text { assimētrica }\end{array}$ \\
\hline $\begin{array}{l}\text { ARA I } \\
\text { ARA II } \\
\text { ARA III }\end{array}$ & $\begin{array}{l}\text { triangular } \\
\text { oval } \\
\text { trapezoidal }\end{array}$ & $\begin{array}{c}\text { pouco simétrica } \\
\text { pouco simétrica } \\
\text { assimëtrica }\end{array}$ \\
\hline $\begin{array}{l}\text { VAP I } \\
\text { VAP II } \\
\text { VAP III }\end{array}$ & $\begin{array}{l}\text { oval } \\
\text { triangular } \\
\text { oval }\end{array}$ & $\begin{array}{c}\text { simétrica } \\
\text { simëtrica } \\
\text { pouco simētrica }\end{array}$ \\
\hline $\begin{array}{l}\text { CAN I } \\
\text { CAN II } \\
\text { CAN III }\end{array}$ & $\begin{array}{l}\text { triangular } \\
\text { triangular } \\
\text { trapezoidal }\end{array}$ & $\begin{array}{l}\text { assimëtrica } \\
\text { assimëtrica } \\
\text { assimëtrica }\end{array}$ \\
\hline
\end{tabular}




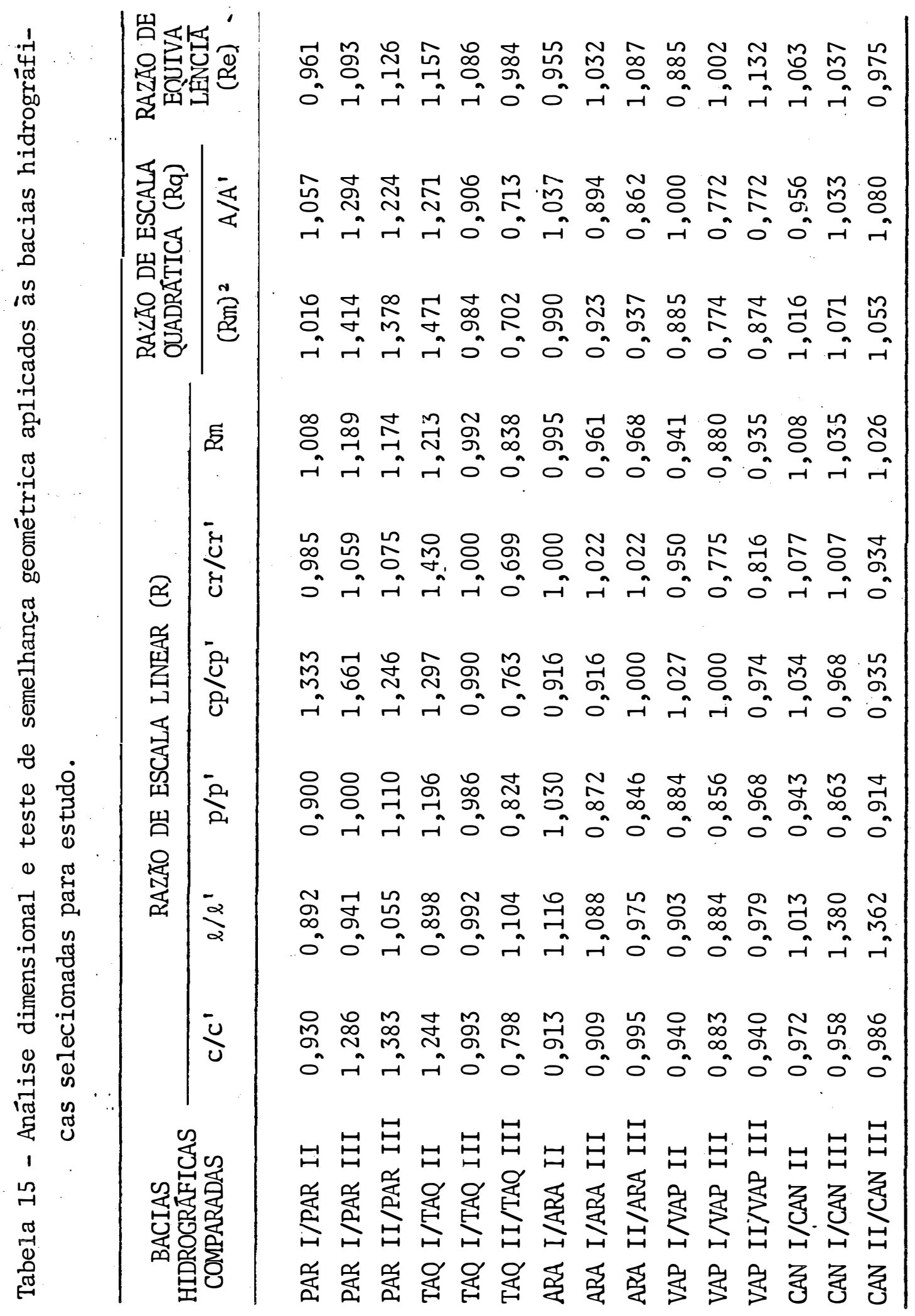


4.4 - Anālise das Redes de Drenagem

4.4.1 - Composição da rede de drenagem

4.4.4.1 - Anā1ise do número de segmentos de rios

O nümero de segmentos de rios observados em cada ordem de ramificação, o número total, o valor mēdio e seu respectivo erro padrão, para as bacias hidrogrāficas re presentativas das unidades de solo em estudo, estão indica dos na Tabela 16 .

Os resultados da análise estatística relatí va a esses dados, encontram-se na Tabela 17.

$$
\begin{aligned}
& \text { 4.4.1.2 - Análise dos comprimentos dos seg } \\
& \text { mentos de rios }
\end{aligned}
$$

Os comprimentos totais de segmentos de rios em cada ordem de ramificação, médias e respectivos erros padrões estão indicados na Tabela 18. A anālise estatística desses dados é representada na Tabela 19.

os comprimentos mēdios de segmentos de rios em cada ordem de ramificação (comprimento/nümero de segmen tos), para cada bacia hidrógräficà; médias e respectivos er ros padrões encontram-se na Tabela 20. Os resuitados da anā 1ise estatística desses dados são apresentados na Tabela 21 . 
Tabela 16 - Número de segmentos de rios observados em cada ordem de ra mificação: e o total para as bacias hidrogräficas; mẻdias e respectivos erros padrões.

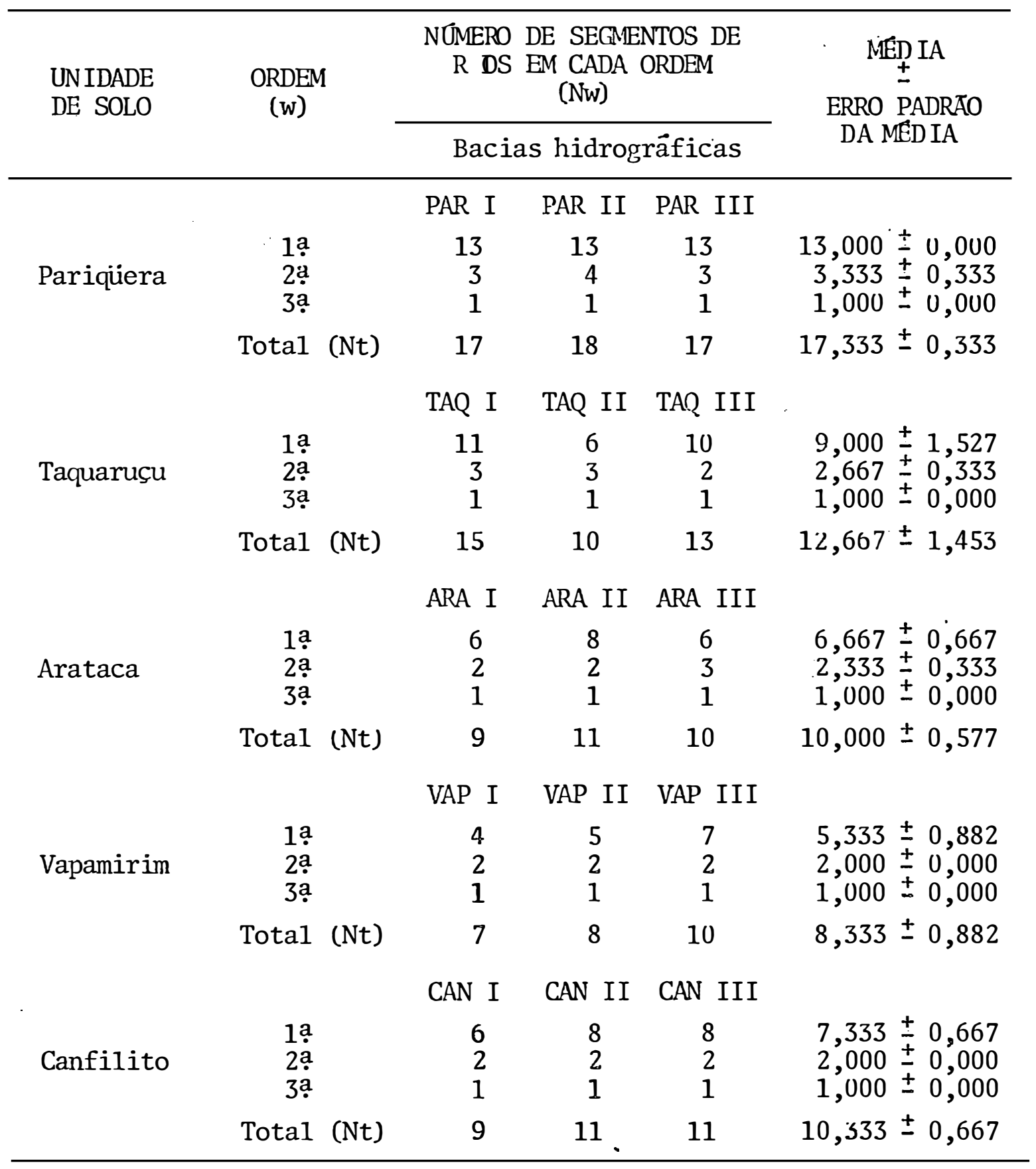




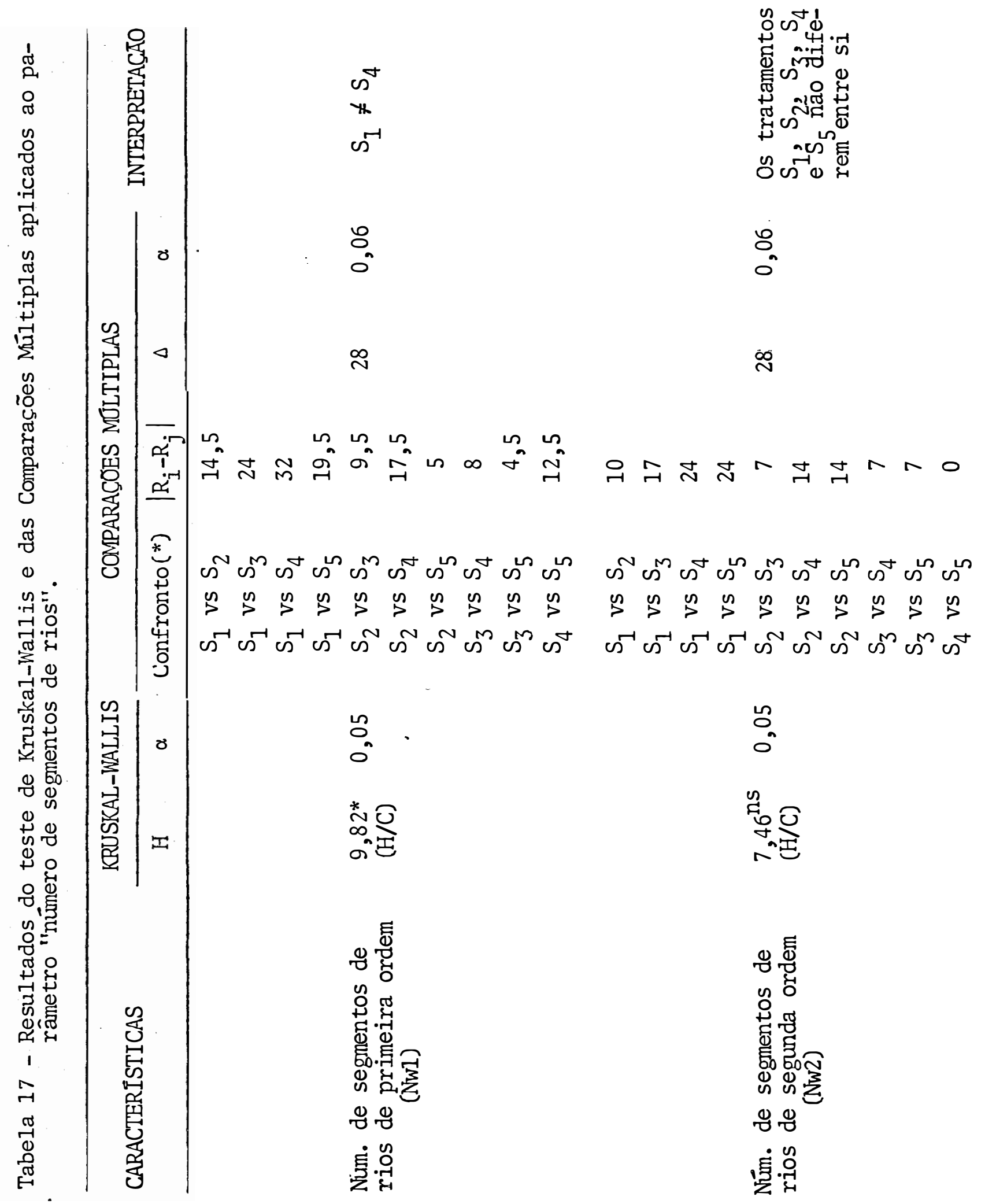




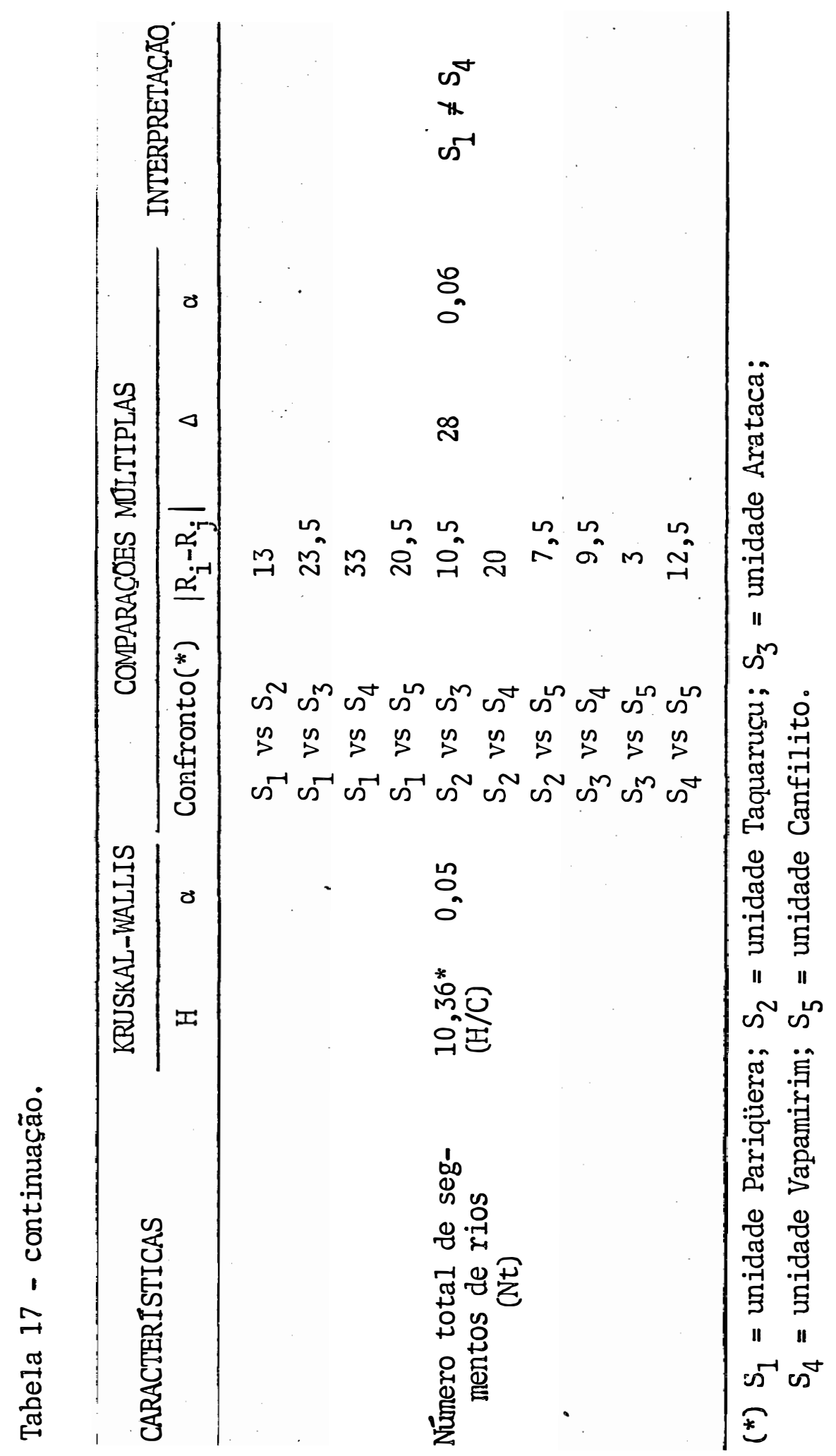


Tabela 18 - Comprimentos totais de segmentos de rios em cada ordem de ramificação; médias e respectivos erros padrões.

\begin{tabular}{|c|c|c|c|c|c|}
\hline \multirow{2}{*}{$\begin{array}{l}\text { UNIDADE } \\
\text { DE SOLO }\end{array}$} & \multirow{2}{*}{$\begin{array}{l}\text { ORDEM } \\
(w)\end{array}$} & \multicolumn{3}{|c|}{$\begin{array}{l}\text { COMPRIMENTO TOTAL DE SEG- } \\
\text { MENTOS DE RIOS FM CADA OR } \\
\text { DEM, LW }(\mathrm{km})\end{array}$} & \multirow{2}{*}{ 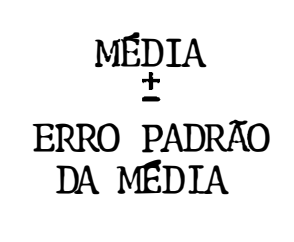 } \\
\hline & & \multicolumn{3}{|c|}{ Bacias hidrogräficas } & \\
\hline \multirow{4}{*}{ Pariqüera } & & PAR I & PAR II & PAR III & \\
\hline & $\begin{array}{l}1 \stackrel{a}{a} \\
2 \stackrel{a}{a} \\
3 \stackrel{a}{a}\end{array}$ & $\begin{array}{l}1,450 \\
2,250 \\
1,250\end{array}$ & $\begin{array}{l}2,500 \\
1,300 \\
1,225\end{array}$ & $\begin{array}{l}2,575 \\
1,050 \\
1,050\end{array}$ & $\begin{array}{l}2,175 \pm 0,363 \\
1,533 \pm 0,365 \\
1,175 \pm 0,063\end{array}$ \\
\hline & Tota1 (Lt) & 4,950 & 5,025 & 4,675 & $4,883 \pm 0,106$ \\
\hline & & TAQ I & TAQ II & TAQ III & \\
\hline \multirow[t]{3}{*}{ Taquaruçu } & $\begin{array}{l}1 \stackrel{a}{a} \\
2 \stackrel{a}{a} \\
3 \stackrel{a}{a}\end{array}$ & $\begin{array}{l}2,050 \\
0,725 \\
0,675\end{array}$ & $\begin{array}{l}1,275 \\
0,637 \\
0,500\end{array}$ & $\begin{array}{l}2,050 \\
0,500 \\
0,900\end{array}$ & $\begin{array}{l}1,792 \pm 0,258 \\
0,621 \pm 0,065 \\
0,692 \pm 0,116\end{array}$ \\
\hline & Tota1 (Lt) & 3,450 & 2,412 & 3,450 & $3,104 \pm 0,346$ \\
\hline & & ARA I & ARA II & ARA III & \\
\hline \multirow[t]{3}{*}{ Arataca } & $\begin{array}{l}1 \dot{a} \\
2 \stackrel{a}{a} \\
3 \stackrel{a}{a}\end{array}$ & $\begin{array}{l}0,750 \\
0,787 \\
0,175\end{array}$ & $\begin{array}{l}0,750 \\
0,412 \\
0,550\end{array}$ & $\begin{array}{l}0,625 \\
0,675 \\
0,375\end{array}$ & $\begin{array}{l}0,708 \pm 0,042 \\
0,625 \pm 0,111 \\
0,367 \pm 0,108\end{array}$ \\
\hline & Tota1 (Lt) & 1,712 & 1,712 & 1,675 & $1,700 \pm 0,012$ \\
\hline & & VAP I & VAP II & VAP III & \\
\hline \multirow[t]{3}{*}{ Vapamirim } & $\begin{array}{l}1 \stackrel{a}{a} \\
2 \stackrel{a}{a} \\
3 \stackrel{a}{a}\end{array}$ & $\begin{array}{l}0,400 \\
0,375 \\
0,175\end{array}$ & $\begin{array}{l}0,500 \\
0,325 \\
0,175\end{array}$ & $\begin{array}{l}0,750 \\
0,200 \\
0,275\end{array}$ & $\begin{array}{l}0,550 \pm 0,104 \\
0,300 \pm 0,052 \\
0,208 \pm 0,033\end{array}$ \\
\hline & lotal (Lt) & 0,950 & 1,000 & 1,225 & $1,058 \pm 0,084$ \\
\hline & & CAN I & CAN II & CAN III & \\
\hline \multirow[t]{2}{*}{ Canfilito } & $\begin{array}{l}1 \stackrel{1}{a} \\
2 \stackrel{a}{a} \\
3 \stackrel{a}{a}\end{array}$ & $\begin{array}{l}0,825 \\
0,662 \\
0,250\end{array}$ & $\begin{array}{l}0,800 \\
0,387 \\
0,425\end{array}$ & $\begin{array}{l}0,750 \\
0,750 \\
0,225\end{array}$ & $\begin{array}{l}0,792 \pm 0,022 \\
0,600 \pm 0,109 \\
0,300 \pm 0,063\end{array}$ \\
\hline & Total (Lt) & 1,737 & 1,612 & 1,725 & $1,691 \pm 0,040$ \\
\hline
\end{tabular}


106.

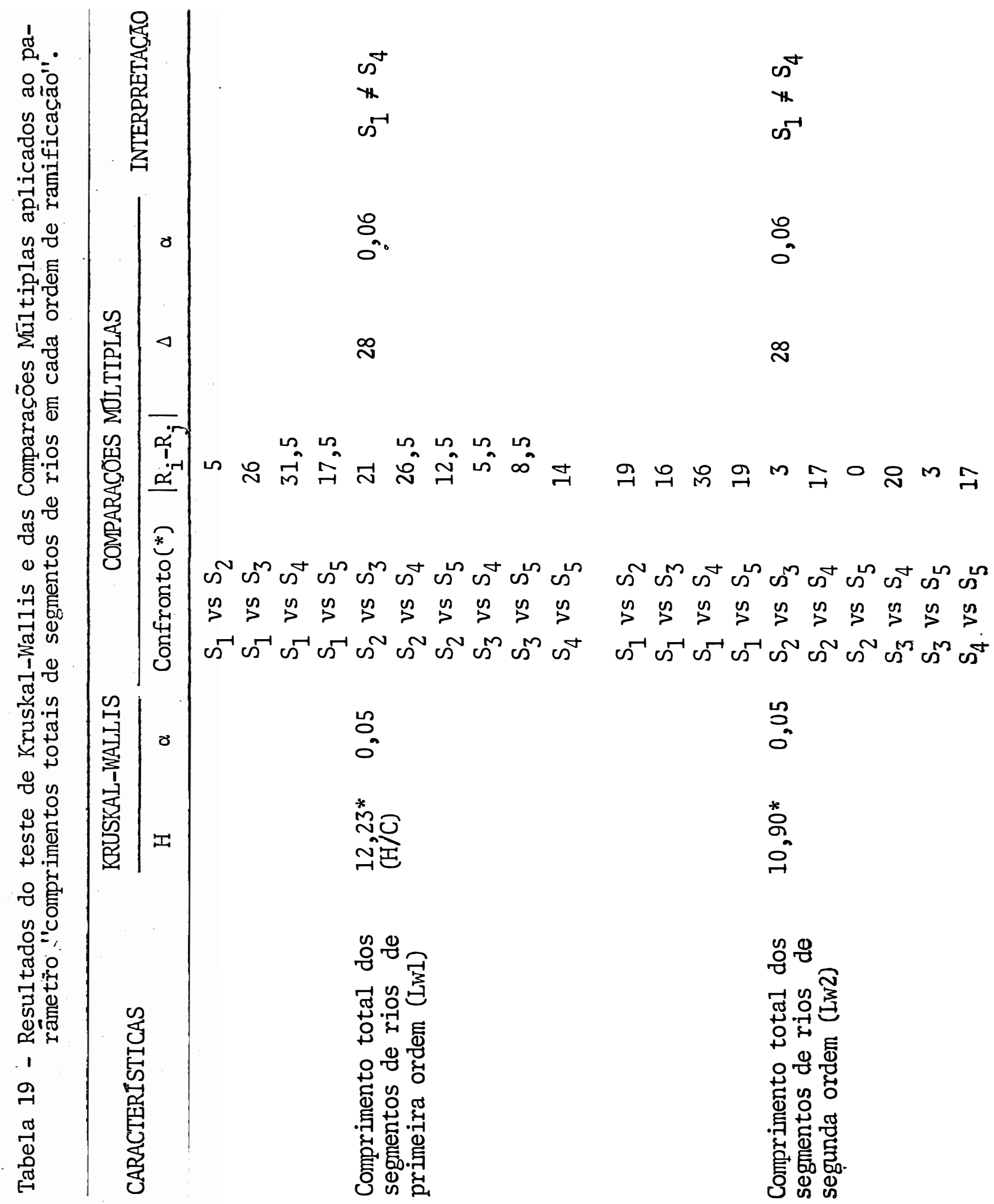




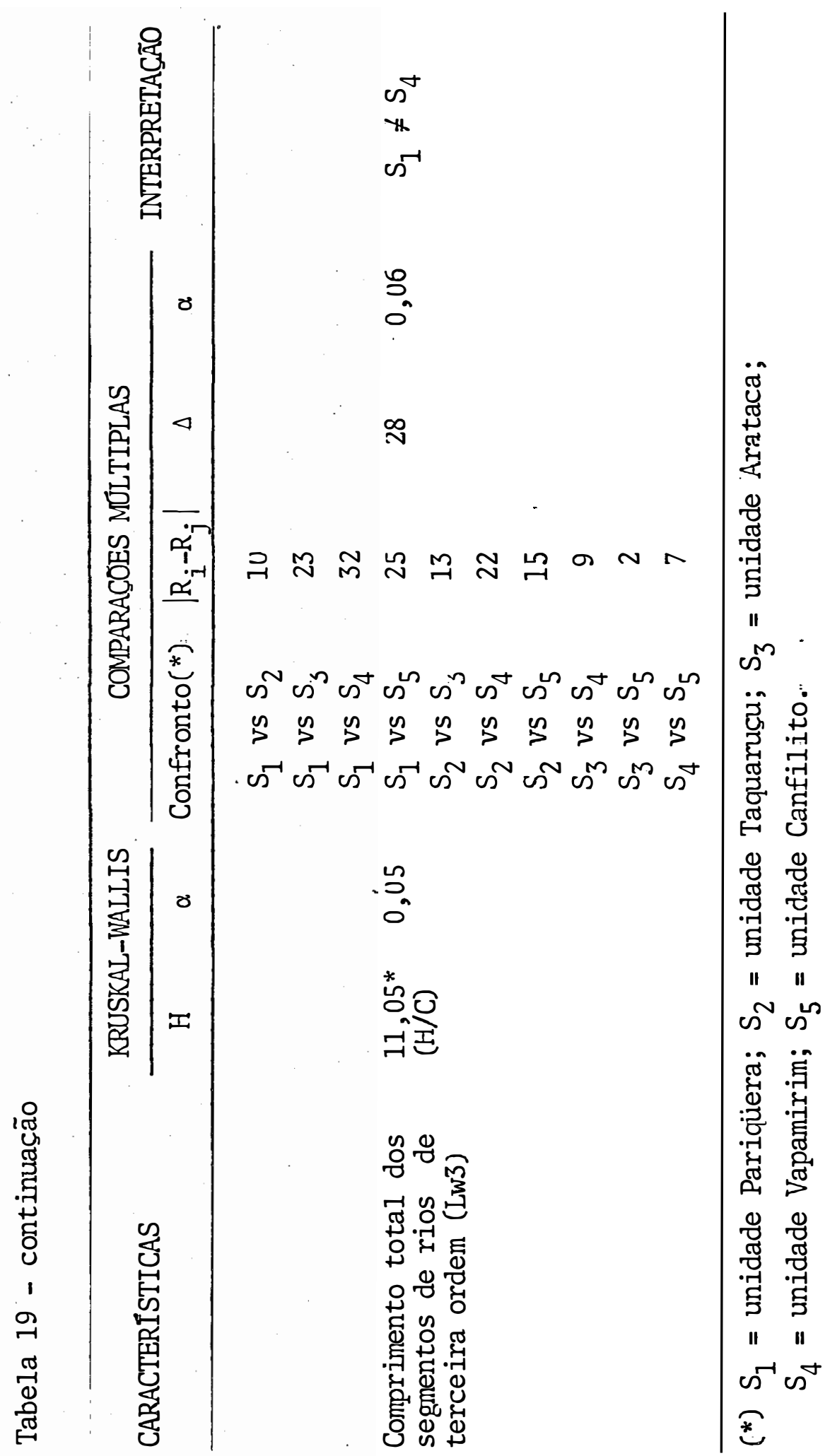


Tabela 20 - Comprimento médio de segmentos de rios em cada ordem de ra mificação; médias e respectivos erros padrões.

\begin{tabular}{|c|c|c|c|c|c|}
\hline \multirow[t]{3}{*}{$\begin{array}{l}\text { UNIDADE } \\
\text { DE SOLO }\end{array}$} & \multirow[t]{3}{*}{$\begin{array}{l}\text { ORDEM } \\
\text { (w) }\end{array}$} & \multicolumn{3}{|c|}{$\begin{array}{c}\text { COMPRIMENTO MEDIO DE SEG- } \\
\text { MENTOS DE RIOS EM CADA } \\
\text { ORDEM, LWm }(\mathrm{km})\end{array}$} & \multirow{3}{*}{$\begin{array}{c}\text { MEDIA } \\
\frac{ \pm}{\text { PARR }} \\
\text { ERRO PADRAO } \\
\text { DA MEDIA }\end{array}$} \\
\hline & & \multicolumn{3}{|c|}{ Bacias hidrogräficas } & \\
\hline & & PAR I & PAR II & PAR III & \\
\hline Pariqüera & $\begin{array}{l}1 \stackrel{a}{a} \\
2 \stackrel{a}{a} \\
3 \stackrel{a}{a}\end{array}$ & $\begin{array}{l}0,111 \\
0,750 \\
1,250\end{array}$ & $\begin{array}{l}0,192 \\
0,325 \\
1,225\end{array}$ & $\begin{array}{l}0,198 \\
0,350 \\
1,050\end{array}$ & $\begin{array}{l}0,167 \pm 0,028 \\
0,475 \pm 0,138 \\
1,175 \pm 0,063\end{array}$ \\
\hline & & TAQ I & TAQ II & TAQ III & \\
\hline Taquaruçu & $\begin{array}{l}1 \stackrel{a}{a} \\
2 \stackrel{a}{a} \\
3 \stackrel{a}{a}\end{array}$ & $\begin{array}{l}0,186 \\
0,242 \\
0,675\end{array}$ & $\begin{array}{l}0,212 \\
0,212 \\
0,500\end{array}$ & $\begin{array}{l}0,205 \\
0,250 \\
0,900\end{array}$ & $\begin{array}{l}0,201 \pm 0,007 \\
0,235 \pm 0,011 \\
0,692 \pm 0,116\end{array}$ \\
\hline & & ARA I & ARA II & ARA III & \\
\hline Arataca & $\begin{array}{l}1 \stackrel{a}{a} \\
2 \stackrel{a}{a} \\
3 \stackrel{a}{a}\end{array}$ & $\begin{array}{l}0,125 \\
0,393 \\
0,175\end{array}$ & $\begin{array}{l}0,094 \\
0,206 \\
0,550\end{array}$ & $\begin{array}{l}0,104 \\
0,225 \\
0,375\end{array}$ & $\begin{array}{l}0,108 \pm 0,009 \\
0,275 \pm 0,059 \\
0,367 \pm 0,108\end{array}$ \\
\hline & & VAP I & VAP II & VAP III & \\
\hline · Vapamirim & $\begin{array}{l}1 \stackrel{a}{a} \\
2 \stackrel{a}{a} \\
3 \stackrel{a}{a}\end{array}$ & $\begin{array}{l}0,100 \\
0,187 \\
0,175\end{array}$ & $\begin{array}{l}0,100 \\
0,162 \\
0,175\end{array}$ & $\begin{array}{l}0,107 \\
0,100 \\
0,275\end{array}$ & $\begin{array}{l}0,102 \pm 0,002 \\
0,150 \pm 0,026 \\
0,208 \pm 0,033\end{array}$ \\
\hline & & CAN I & CAN II & CAN III & \\
\hline Canfilito & $\begin{array}{l}1 \stackrel{a}{a} \\
2 \underset{a}{a} \\
3 \stackrel{a}{a}\end{array}$ & $\begin{array}{l}0,137 \\
0,331 \\
0,250\end{array}$ & $\begin{array}{l}0,100 \\
0,193 \\
0,425\end{array}$ & $\begin{array}{l}0,094 \\
0,375 \\
0,225\end{array}$ & $\begin{array}{l}0,110 \pm 0,013 \\
0,300 \pm 0,055 \\
0,300 \pm 0,063\end{array}$ \\
\hline
\end{tabular}


109.

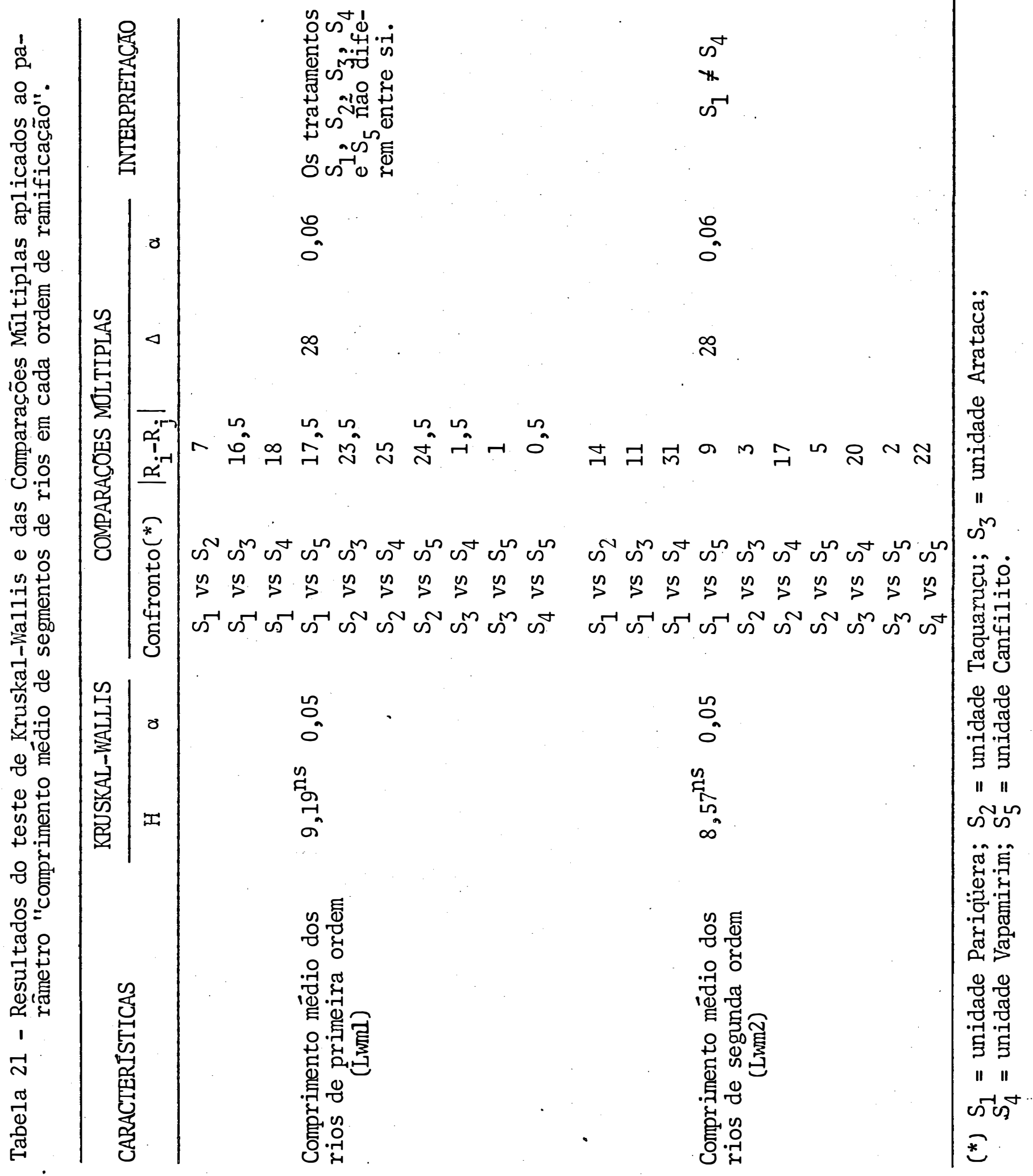


4.4.2 - Características do padrāo de drenagem 4.4.2.1 - Características descritivas

As características descritivas do padrão de drenagem, referentes às redes de drenagem das bacias hidró gräficas representativas das unidades de solo em estudo,es tão apresentadas na Tabela 22 .

$$
\text { 4.4.2.2 - Características quantitativas }
$$

As caracteristicas quantitativas do padrão de drenagem, determinadas nas bacias hidrogräficas repre. sentativas das unidades de solo em estudo, são mostradas na Tabe1a 23 .

Os resultados da análise estatística, referentes a essas características, encontram-se na Tabela 24 . 


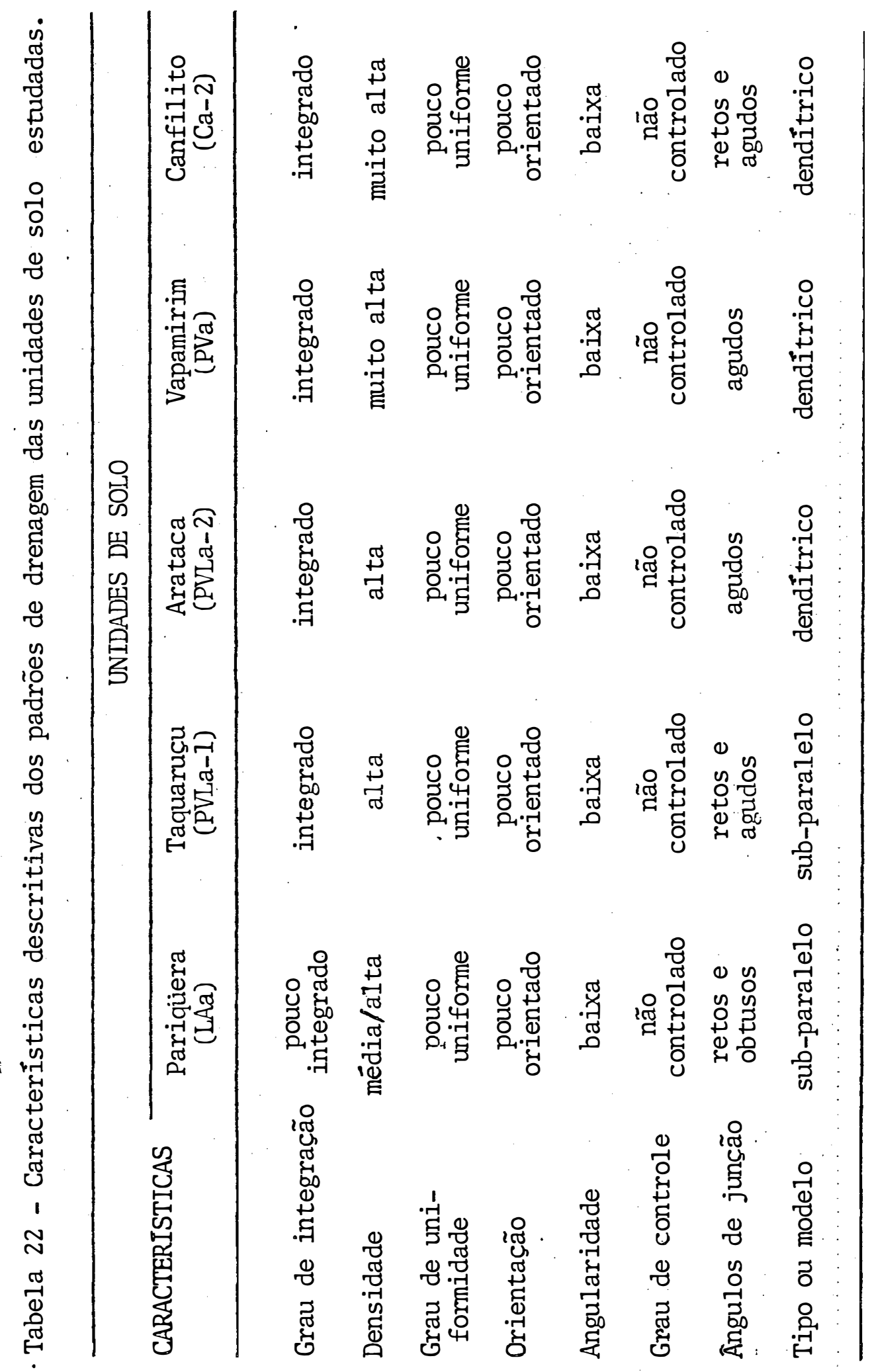




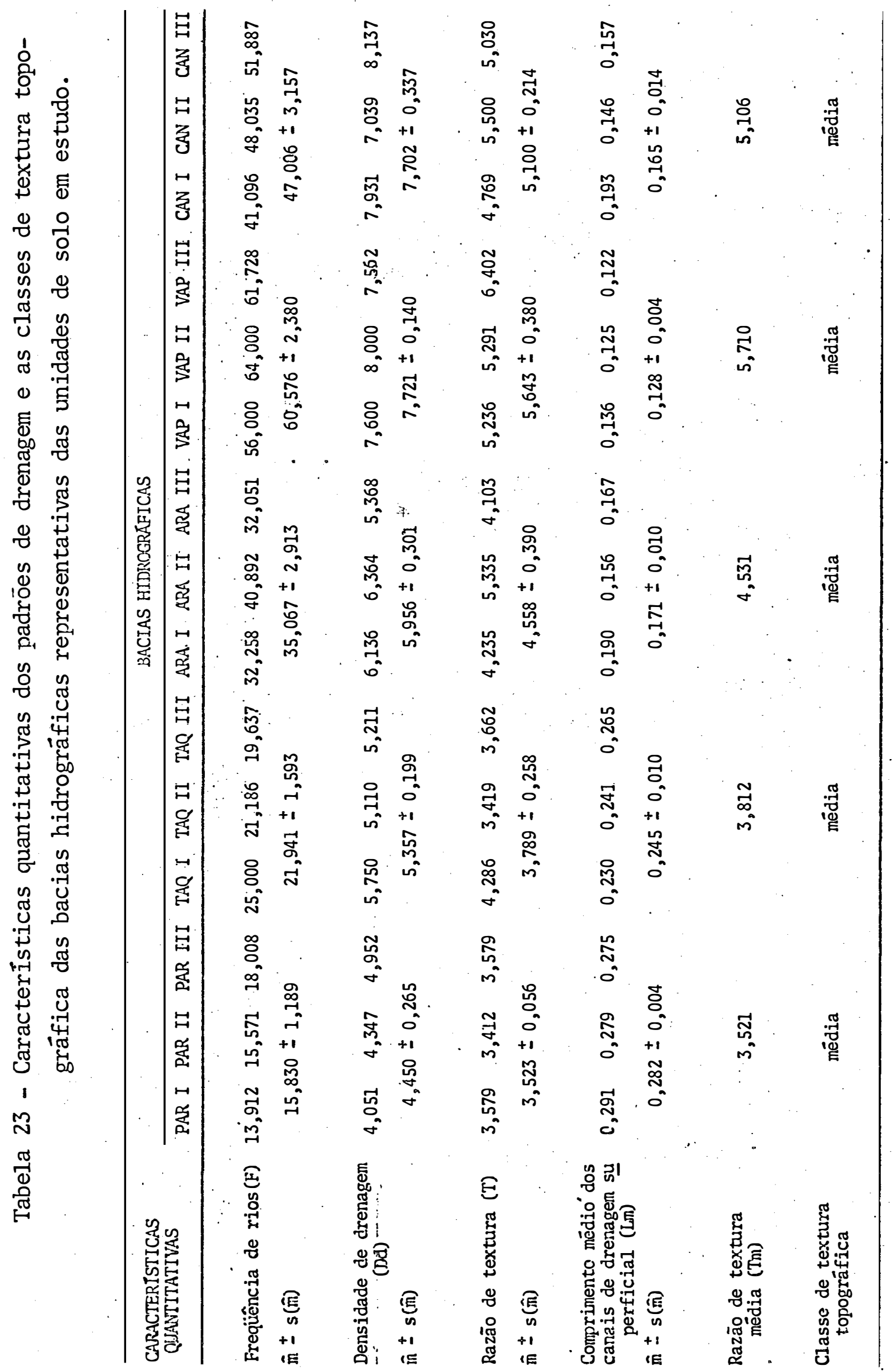


113.

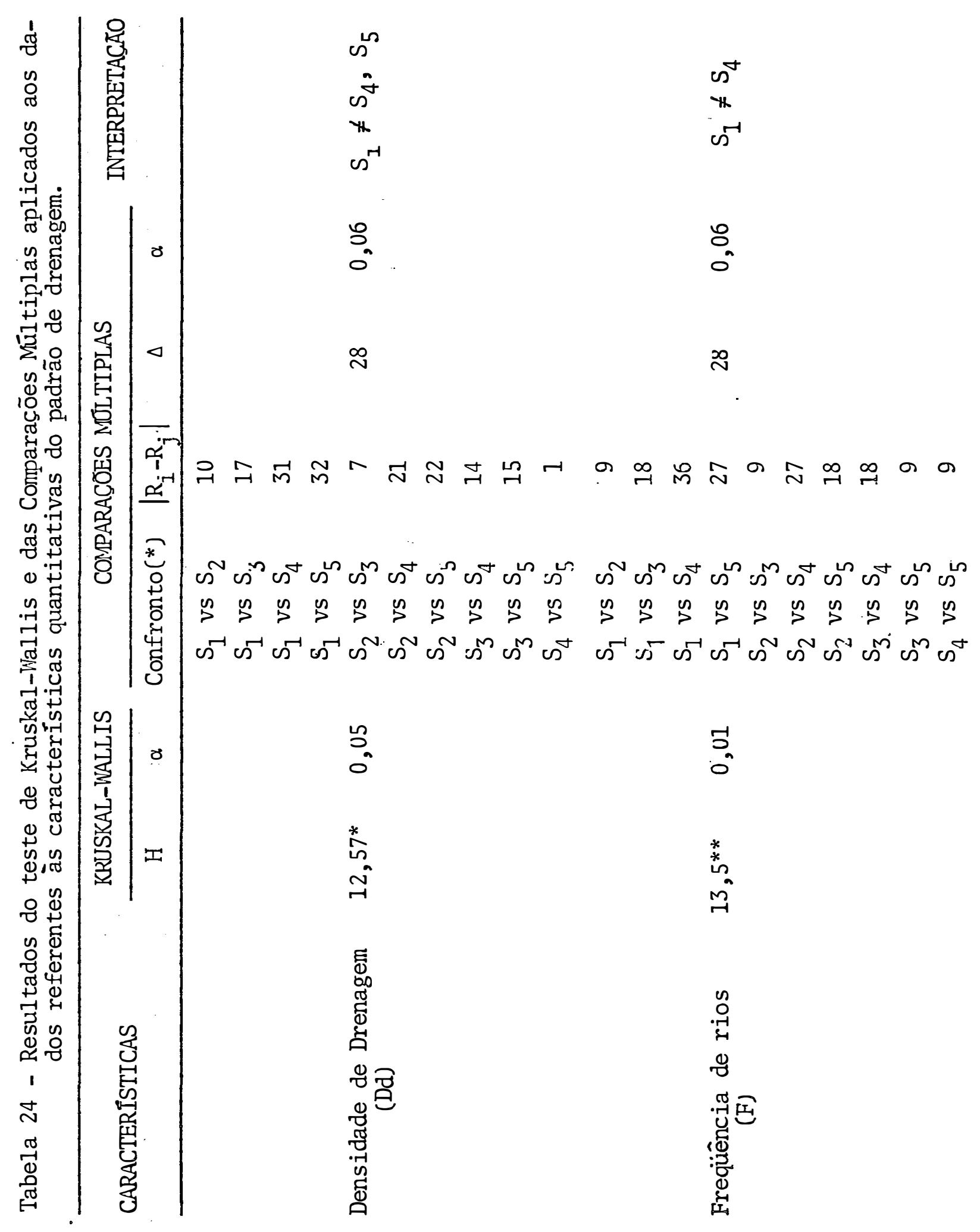




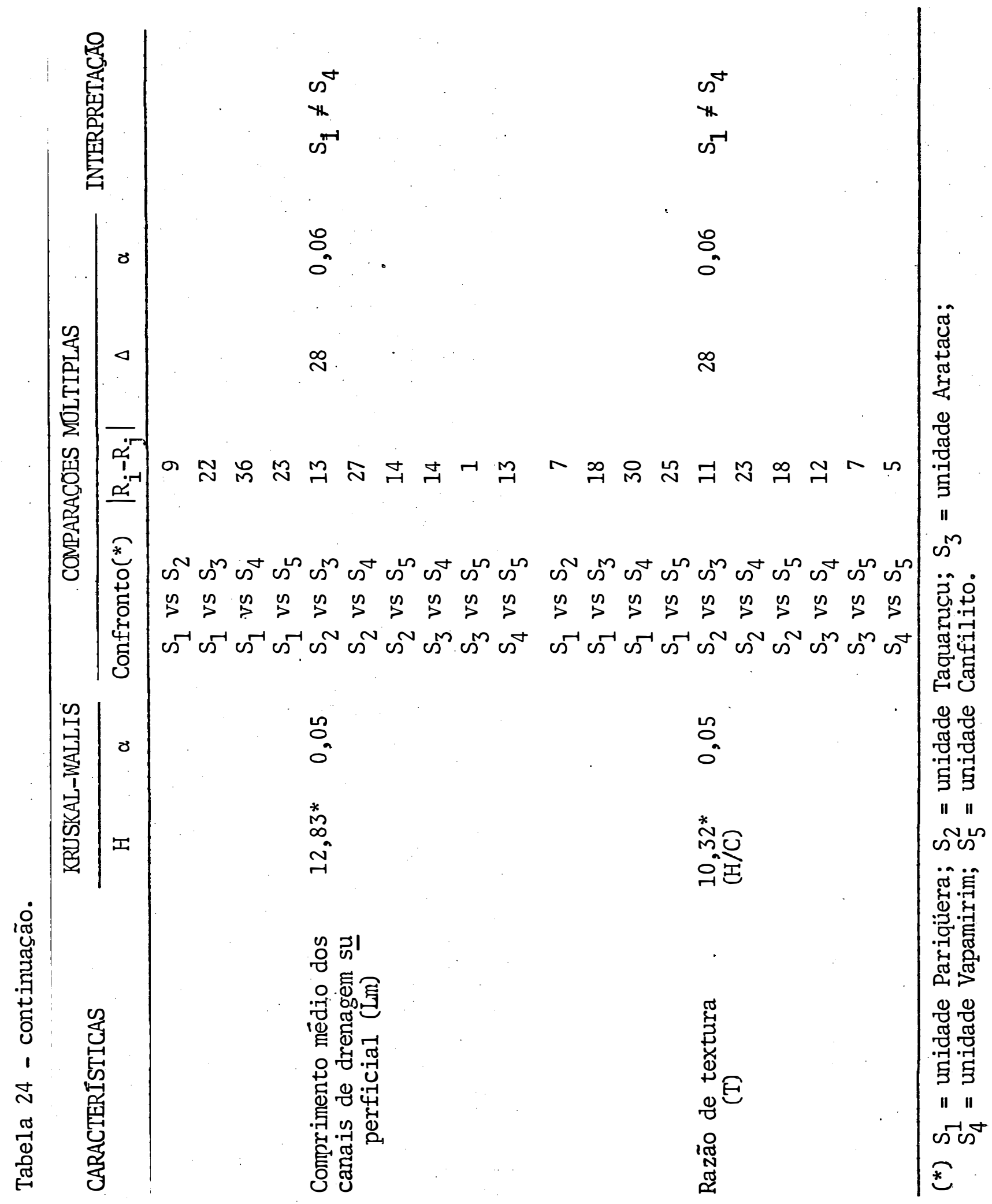


115.

\section{DISCUSSÃO DOS RESULTADOS}

\section{1 - Mapas Básicos de Drenagem}

Os mapas básicos de drenagem facilitaram na visão geral da distribuição das bacias hidrográficas de tẹ ceira ordem de ramificação, demarcadas sobre eles, ressaltando as variações geomêtricas existentes entre essas bacias; e, tambêm, na análise descritiva da rede de drenagem de cada unidade de solo estudada.

5.2 - Seleção das Bacias Hidrográficas e Teste de Seme1hança Geomêtrica

Tendo em vista a necessidade de alta representatividade das unidades amostrais, em relação às respec 
tivas unidades de solo, o processo de seleção empregado nes te trabalho resultou em bacias hidrogräficas cujas características apresentaram suficiente homogeneidade dentro de ca da unidade de solo (STRAHLER, 1957), o que pode ser constatado pela observação das Figuras 12 a 16 , bem como pela aná 1ise dos resultados gerais deste trabalho.

A anälise dimensional e teste de semelhança geométrica, aplicados as bacias hidrogrâficas selecionadas, tambëm demonstraram a homogeneidade existente entre as amos tras de cada solo.

Pela observação dos dados apresentados na Taㅡ bela 15, nota-se pequena variação nos valores da Razão de Equivalência (Re), proposta por MANECHINI (1981), em torno do valor unitärio.

O critērio de empregar apenas bacias de terceira ordem de ramificação, como unidades amostrais, è justificado pela observação de PARVIS (1950) de que, ā medida que aumenta a ordem de ramificação o rio escava mais profundamente o seu vale, abaixo da profundidade efetiva do so 1o, atingindo o substrato rochoso e permitindo, dessa manei ra, inferências fotointerpretativas mais relacionadas com o substrato do que com o solo propriamente dito. Essas inferências podem mostrar diferenças litolögicas, ou influências de controles estruturais. 


\section{3 - Anālise das Bacias Hidrogräficas}

\subsection{1 - Propriedades dimensionais}

Os valores relativos às propriedades dimensionais das bacias hịdrográficas, que são: maior comprimen to, maior largura, perimetro, comprimento do rio principal, comprimento total da rede e ärea, apresentados na Tabela 12, mostram diferenças entre as unidades de solo, à exceção das unidades Arataca (PVLa-2) e Canfilito (Ca-2), cujos valores médios para os parâmetros analisados são muito prôximos.

Observa-se uma diminuição gradual nos valores dos parämetros, da unidade Pariqüera (LAa) à unidade Vapamirim (PVa), concordando com a maioria dos resultados obtidos por pesquisadores que trabalharam com solos de horizonte B latossōlico e horizonte B textural, como FRANCA (1968), MARCHETTI (1969), FADEL (1972), GEVAERD (1974), MA NECHINI (1981), PFEIFER (1984) e GUIMARÃES (1984)。

Essa variação gradual provavelmente deve-se à classe de relevo de ocorrência de cada solo, indo do sua ve ondulado para o Latossolo ao ondulado para o Podzólico, aliada à natureza e propriedades dos solos, notadamente àquelas ligadas à taxa infiltração/deflưvio. 
No caso do Cambissolo (unidade Canfilito), os resultados o colocam em posição intermediāria entre os Podzólicos Vermelho-Amarelos Latossólicos e o Podzólico Ver melho-Amare1o, com valores semelhantes aos da unidade Arataca. Somente o relevo não justifica essa semelhança, dada à diferença de ocorrência desses dois solos; enquanto o Arataca ocorre em relevo suave ondulado a ondulado, o Canfilito aparece em relevo forte ondulado a montanhoso. Possivelmente, uma ação combinada do relevo e características morfológicas sobre o Canfilito, o tenha levado a essa seme 1hança com o Arataca, em termos de propriedades dimensionais das bacias hidrogräficas.

A anālise estatística (Tabela 13) dos dados: referentes às propriedades dimensionais das bacias indicou, para todos os parâmetros analisados, que há uma diferença significativa, a uma taxa de $6 \%$ de erro experimental, entre as unidades Pariquiera e Vapamirim. Ainda, observando-se a coluna de $\left|R_{i}-R_{j}\right|$ dos confrontos, nas comparações mü tiplas, percebe-se que os resultados de $\mathrm{S}_{1}$ "versus" $\mathrm{S}_{5}$ e $\mathrm{S}_{2}$ "versus" $\mathrm{S}_{4}$, encontram-se bem próximos do valor de $\Delta$ (dife. rença mínima significativa). 


\subsection{2 - Propriedades não dimensionais}

Pela observação das Figuras 12 a 16 e da Tabela 14, nota-se uma heterogeneidade no que se refere às propriedades não dimensionais das bacias hidrogräficas, den tro de cada unidade de solo. A forma aproximada das bacias variou bastante para as amostras, tendendo a uma maior seme1hança nas unidades Vapamirim e Canfilito. Quanto à sime tria das vertentes, a tendência geral foi a ocorrência de assimetria, à exceção da unidade Vapamirim.

Autores como FRANÇA (1968), MARCHETTI(1969), VASQUES (1972), POLITANO (1980) e LEÃO (1983), concordam que, geralmente, a simetria das vertentes não apresenta dí ferenças entre os solos estudados.

\section{4 - Análise das Redes de Drenagem}

5.4.1 - Composição das redes de drenagem

$$
\begin{aligned}
& \text { 5.4.1.1 - Anälise de nümero de segmentos } \\
& \text { de rios }
\end{aligned}
$$

Os resultados apresentados na Tabela 16 mos tram que os parâmetros "nủmero de segmentos de rios de pri meira ordem" e "nümero total de segmentos de rios" refletem diferenças entre as unidades de solo Pariqüera e Vapa mirim。 
Segundo a Lei de Horton modificada por Strah ler, os números de segmentos de rios de cada ordem de rami ficação formam uma sërie geomẹtrica inversa àquela do nüme ro de ordem. Os resultados obtidos, apresentados na Tabela 16, confirmam esta lei, concordando com HORTON (1945), STRAH LER (1952) e com aqueles que estudaram a sua aplicação em solos, como FRANCA (1968), MARCHETTI (1969) e outros.

0 número total e o número de segmentos de rios de primeira e segunda ordens, apresentaram tendência geral a diminuir, da unidade Pariqüera à Vapamirim, com a unidade Canfilito apresentando valores novamente bem próxi mos aos da unidade Arataca, o que discorda das observações de HORTON (1945) e de LUEDER (1959). Segundo estes autores, o número de rios aumenta em proporção inversa ao valor absoluto da relação infiltração/deflúvio ou, sob outro aspec to, na razão direta da erodibilidade das unidades de solo.

Há que se considerar dois aspectos na análi se desses resultados. Em primeiro lugar, tratam-se de unidades de solo cujas bacias hidrogräficas são bastante contrastantes em relação às dimensões de suas superfícies; en quanto as bacias da unidade Pariquera apresentam um valor mëdio de ärea igual a $1,107 \mathrm{~km}^{2}$, as da unidade Vrapamirim apresentam o valor de $0,137 \mathrm{~km}^{2}$. Em segundo lugar è neces- 
sario levar em consideração que a região do Ribeira apresenta uma pluviosidade relativamente elevada, como mostram a Tabela 3 e a Figura 2, com maior concentração nos meses de verão, colaborando para a formação de uma rede de drena gem superficial, no geral mais densa que aquelas ocorrentes no restante do Estado de São Paulo.

A aplicação do teste de Kruska1-Wa1lis e das Comparações Múltiplas aos dados de nümero total de segmentos de rios, que compõem a Tabela 17, trouxe como resultado a possibilidade de diferenciação, a uma taxa de $6 \%$ de erro experimental, entre as unidades Pariqüera e Vapamirim. 0 mesmo aconteceu quanto ao parâmetro"nümero de segmentos de rios de primeira ordem". Já para o nūmero de segmentos de rios de segunda ordem, ao nivel de $6 \%$ de probabilidade, a estatística empregada não permitiu diferenciação entre os solos estudados.

5.4.1.2 - Análise do comprimento dos segmentos de rios

A mesma tendência observada com relação ao parâmetro"nümero de segmentos de rios", aparece tambēm em "comprimentos dos segmentos de rios", ou seja, uma diminuição nos valores, tanto dos comprimentos totais como dos compri 
mentos de segmentos de rios de cada ordem, da unidade Par $\underline{i}$ qüera para a Vapamirim, com valores intermediārios para as unidades Taquaruçu, Arataca e Canfilito, o que é constatado pelo exame dos dados da Tabela 18. Essa tendência geral dos dados, para o caso específico dos solos estudados, dis corda da observação de CARVALHO (1977), para quem o compri mento total de rios ē um parâmetro que, isolado, não refle te as condições hidrológicas das unidades de solo.

Os resultados da análise estatística para esses dados (Tabela 19) mostraram que, ao nīvel de $6 \%$ de probabilidade, é possível diferenciar-se as unidades Pariqüera e Vapamirim. Nota-se também que, no caso do comprimento total dos segmentos de rios de primeira ordem, as di ferenças $\left|R_{i}-R_{j}\right|$ para os confrontos $S_{1}$ "versus" $S_{3}$ e $S_{2}$ "versus" $\mathrm{S}_{4}$, apresentaram resultados muito pröximos ao valor $\Delta$ (diferença mínima significativa).

Os comprimentos médios de segmentos de rios em cada ordem de ramificação, apresentados na Tabela 20 e a respectiva análise estatística (Tabela 21), mostram resultado interessante no caso do comprimento médio dos segmentos de rios de primeira ordem, onde, ao nível de $6 \%$ de probabilidade, não houve diferenciação estatística entre as cinco unidades de solo. Isso parece confirmar a importância, na formação da rede de drenagem local, do fa- 
tor clima, através da precipitação relativamente elevada e sua concentração maior em determinada época do ano, concor dando com a observação de RAMALHO e HAUSEN (1975) a respe $\underline{i}$ to da atuação do clima sobre a rede de drenagem.

\subsection{2 - Caracterĩsticas do padrão de drenagem 5.4.2.1 - Características descritivas}

As caracteristicas descritivas dos padrōes de drenagem, apresentadás na Tabela 22 , apresentaram valor limitado na distinção entre as unidades de solo, pois, como cita MANECHINI (1981), as mesmas sāo estabelecidas por critério comparativo, passível de interpretaçẽes subjetivas, concordando com HORTON (1945), STRAHLER (1957), FRANÇA (1968) e vârios outros autores.

A maior diferenciação entre as unidades de solo, com respeito às características descritivas, foi observada pelo baixo grau de integração para a unidade Pariqüera e integrado para as demais unidades; na densidade, média para a unidade Pariqüera e alta para as demais; nos ângulos de junção, retos e obtusos para a unidade Pariqüera, retos e agudos para as unidades Taquaruçu e Canfilito, e agudos para as unidades Arataca e Vapamirim; e no tipo 
ou modelo, sub-paralelo para as unidades Pariqüera e Taqua ruçu e dendrítico para as restantes.

Com relação às demais características (grau de uniformidade, orientação, angularidade e grau de contro 1e) não houve distinção entre as unidades de solo estudadas.

Embora de valor relativo, a caracterização descritiva do padrão de drenagem, auxiliou na interpretação do comportamento hidrológico das unidades de solo, for necendo indícios quanto à relação infiltraçäo/deflúvio,prin cipalmente através das características grau de integração, densidade e tipo ou modelo.

\subsubsection{2 - Características quantitativas}

A subjetividade, inerente à caracterização descritiva do padrão de drenagem, é contornada pela análise de características quantitativas do padrão. Com base na objetividade, a caracterização quantitativa foi efetuada através da anâlise dos indices densidade de drenagem, freqüência de rios, comprimento médio dos canais de drenagem superficial, razão de textura e razão de textura mēdia. Pe lo valor obtido para o indice razão de textura média, foi 
ainda possível classificar a textura topogräfica, conforme adaptação de FRANÇA (1968) da classificação de SMITH(1950). $\mathrm{Na}$ fotointerpretação aplicada a solos, vārios autores, dentre eles FRANÇA (1968), MARCHETTI (1969), FADEL (1972), VASQUES FILHO (1972), LEÃO (1973), SOUZA (1975), FREIRE (1977) e outros, trabalhando com solos ao nível de sērie e com bacias hidrogrâficas, geralmente de terceira ordem, demonstraram que nessas condições as carac terísticas quantitativas do padrão de drenagem mostraram-se consistentes na diferenciação entre os solos, refletin do a influência do fator solo no desenvolvimento das redes de drenagem.

Pela observação dos resultados apresentados na Tabela 23 , verifica-se que os parâmetros estudados permitem a diferenciação entre as cinco unidades de solo, sen do nitida essa diferenciação no caso do indice 'frequêencia de rios, seguido da densidade de drenagem, concordando com autores como FADEL (1972), LEÃO (1973), SOUZA (1975), CARVALHO (1977) e GUIMARAES (1984)。

A frequêencia de rios, relacionando o número total de segmentos de rios com a área da bacia, mostrou-se um indice consistente, evidenciando a diferença entre as unidades de solo estudadas. 0 mesmo ocorre, porēm em menor proporção, com o indice densidade de drenagem, que relacio 
na o comprimento total de segmentos de rios com a ārea da bacia hidrogrāfica. Os resultados obtidos concordam com a sugestão de HORTON (1945), no sentido de se utilizarem a frequêencia de rios e a densidade de drenagem com a finalidade de caracterizar quantitativamente as redes de drenagem de bacias hidrogräficas, pois estes dois indices relacionam elementos de composição da rede (comprimento total e número de segmentos de rios) à área da bacia.

Os valores de densidade de drenagem refleti ram bem a resistência dos solos à erosão, como observou CAR VALHO (1977). Esse indice variou de um valor igual a 4,450 para a unidade Pariqüera (LAa), solo muito profundo, em re levo suave ondulado, com alta resistência à erosão, a um valor igual a 7,702 para a unidade Canfilito (Ca-2), solo raso ou pouco profundo, em relevo forte ondulado a montanhoso, com baixa resistência à erosão. O valor relativamen te elevado $(7,721)$ de densidade de drenagem observado na unidade Vapamirim (PVa), provavelmente seja decorrência de seu horizonte B textural, aliado ao relevo ondulado, o que the confere uma drenagem interna lenta e uma drenagem externa räpida.As unidades Taquaruçu (PVLa-1) e Arataca(PVLa-2) apresentaram valores intermediärios de densidade de drenagem, respectivamente 5,357 e 5,956 . 
Os valores obtidos para os indices razão de textura, razāo de textura média e comprimento médio dos ca nais de drenagem superficial, quando observados de modo glo ba1, também permitem diferenciação entre as cinco unidades de solo. Quando, porém, a textura topogräfica foi classifi cada, a partir dos valores de razão de textura média, não houve diferenciação entre os solos, com todas as unidades enquadrando-se na classe de textura média:

Os resultados do teste de Kruska1-Wallis e das Comparações Mūltiplas aplicados aos dados referentes às características quantitativas do padrão de drenagem (Tabe1a 24) continuaram, à semelhança do ocorrido com outros pa râmetros analisados, a acusar diferenças estatisticamente significativas, ao nível de $6 \%$ de probabilidade, entre as unidades Pariqüera (LAa) e Vapamirim (PVa), solos morfogeneticamente distintos. Para o indice densidade de drenagem, a unidade Pariqüera diferiu estatisticamente das unidades Vapamirim e Canfilito, ambas semelhantes no que se refere a resistência à erosão. 
128.

\section{CONCLUSOES}

Considerando-se os objetivos deste trabalho, as condições especificas sob as quais foi conduzido e a metodologia utilizada, os resultados obtidos permitiram as seguintes conclusões:

- o processo de seleção das bacias hidrogrāficas empre gado neste trabalho mostrou-se eficiente, conferindo boa homogeneidade e representatividade às unidades amostrais, o que foi confirmado pelos resultados do teste de semelhança geomëtrica;

- a anālise das propriedades dimensionais das bacias hidrográficas acusou diferenças entre os.solos estudados, à exceçāo das unidades. Arataca (PVLa-2) e Can- 
filito (Ca-2), que apresentaram valores médios, para os parâmetros analisados, muito prōximos entre si;

- as propriedades não dimensionais das bacias hidrogrāficas não foram eficientes na distinção entre as unidades de solo estudadas, pois mostraram uma hete rogeneidade generalizada quanto à forma das bacias e uma tendência à assimetria das vertentes;

- a anâlise dos elementos ligados à composição das re des de drenagem, no geral mostrou valores contrastantes para as unidades Pariquiera (LAa) e Vapamirim (PVa), com valores intermediārios para as unidades Taquaruçu (PVLa-1), Arataca (PVLa-2) e Canfilito $(\mathrm{Ca}-2)$;

- alguma diferenciação entre as unidades de solo, com respeito às características descritivas do padrão de drenagem, foi observada no grau de integração,na densidade, nos ângulos de junção e no tipo ou mode10 do padrão;

- o Indice freqüência de rios, seguido da densidade de drenagem, foi altamente eficiente na distinção entre as cinco unidades de solo estudadas; 
- os valores de densidade de drenagem refletiram bem a resistência dos solos à erosão, sendo muito altos para os solos de baixa resistência, como o Vapamirim e o Canfilito; médios para o Pariqüera, que pos sui alta resistência à erosão; e altos para as unidades Taquaruçu e Arataca;

- a caracterização morfológica dos solos estudados foi ūtil na interpretação dos dados relativos às bacias hidrogräficas e respectivas redes de drenagem;

- o emprego dos testes não-paramétricos de Kruska1-Wal lis e das Comparaçōes Mültiplas, foi eficiente na diferenciação entre os solos morfogeneticamente dis tintos, porēm não o foi para solos semelhantes sob esse aspecto. 
131.

\section{LITERATURA CITADA}

AB'SABER, A.N., 1960. Sensibilidade das Fotografias Aéreas em Zonas Tropicais Umidas para Efeito de Fotointerpretação. Not. Geomorfol. Campinas, $\underline{3}$ : 67-72.

AMARAL, A.Z. e R. AUDI, 1972. Fotopedologia. In: MONIZ, A.C., coord., Elementos de Pedologia, EDUSP, p. 429-442.

ANGULO FILHO, R., 1981. Variações de Características de Redes de Drenagem em Função das Fotografias Aẻreas Verticais Obtidas em Epocas Diferentes. Piracicaba, ESALQ/USP, 128 p. [Dissertação de Mestrado].

BOMBERGER, E.H. e H.W. DILL, 1960. Photo Interpretation in Agriculture. In: AMERICAN SOCIETY OF PHOTOGRAMMETRY. Manual of Photographic Interpretation. Washington, p. 561-632.

BRINK, A.B.; J.A. MABBUTT; R. WEBSTER e P.H.T. BECKETT, 1966。 Repport of the Working Group on Land Classification and Data Storage. Mexe Rep. 940. Christchurch, Hants, 95 p. 
BURINGH, P., 1960. The Applications of Aerial Photographs in Soil Sur veys. In: AMERICAN SOCIETY OF PHOTOGRAMMETRY. Manual of Photographic Interpretation. Washington, p. 633-66.

CAMARGO, A.P.; H.S. PINTO; O. BRUNINI; M.J. PEDRO JR.; A.A. ORTOLANI e R.R. ALFONSI, 1974. Clima do Estado de São Paulo. In: SECRETARIA DE AGRICULTURA DO ESTADO DE SAO PAULO. Zoneamento Agrí́cola do Estado de São Paulo. São Paulo, Vol. I, 170 p.

CAMPOS, H., 1979. Estatística Experimental Não-Paramétrica. 3ạ ed., De partamento de Matemätica e Estatística, Piracicaba, ESALQ/USP. 343 p.

CARVALHO, W.A., 1977. Fotointerpretação de Bacias Hidrogräficas e Amos tras Circulares de Redes de Drenagem de Solos com Horizonte B Textu ral. Piracicaba, ESALQ/USP, 126 p. [Tese de Doutoramento].

CHRISTIAN, C.S. e.G.A. STEWART, 1968. Methodology of Integrated Surveys. Nat. Resour. Res., UNESCO, $\underline{6}:$ 233-280.

CHRISTOFOLETTI, A., 1969. Anälise Morfomëtrica das Bacias Hidrogräficas. Not. Geomorfol., Campinas, $\underline{9}(18): 35-64$.

CHRISTOFOLETTI, A. e A.L. CESAR, 1978. Correlação Entre Densidade de Drenagem e Comprimento Médio de Canais em Bacias Hidrogräficas. Ciência e Cultura. São Paulo, 5: 601-604.

COLWELL, R.N., 1952. Photographic Interpretation for Civil Purposes. In: AMERICAN SOCIETY OF PHOTOGRAMMETRY. Manual of Photogrammetry. Washington, p. 535-602。 
COMISSÃO DE SOLOS, 1960. Levantamento de Reconhecimento dos Solos do Estado de São Paulo. Rio de Janeiro, Centro Nacional de Ensino e Pesquisas Agronômicas. 634 p. [Boletim n? 12].

CRESWICK, W.J. e W.H. ROCKWELL, 1959. Applications of Aerial Photographic Techniques to Agricultural Surveys. In: Aerial Photographic Interpretation: Principles and Applications. New York, McGraw-Hill Ed., p. 373-385.

DEMÉTRIO, V.A., 1977. Variação de Características de Redes de Drenagem em Função da Escala das Fotografias Aéreas Verticais. Piracicaba, ESALQ/USP, 107 p. [Disser tação de Mestrado].

DUNBAR, R.A., 1959. Problems of Interpretation in Tropical Regions. In: Aerial Photographic Interpration: Principles and Applications. New York, McGraw-Hill Ed., p. 426-427.

FADEL, H., 1972. Fotointerpretação de Bacias e Redes de Drenagem de Três Séries de Solos da Fazenda Ipanema, $\underline{\mathrm{Mu}}$ nicipio de Araçoiaba da Serra - SP. Piracicaba, ESALQ/ USP, $92 \mathrm{p}$. [Dissertação de Mestrado].

FRANÇA, G.V., 1968. Interpretação Fotogrāfica de Bacias e de Redes de Drenagem Aplicada a Solos da Região de Pira cicaba. Piracicaba, ESALQ/USP, 151 p. [Tese de Doutoramento]. 
FREIRE, J.C., 1977. Fotointerpretação de Redes de Drenagem de Três Solos da Região de Alpinöpolis, Minas Gerais. Piracicaba, ESALQ/USP, 136 p. [Tese de Doutoramento].

FREIRE, O. e J.E.S. PESSOTTI, 1974. Erodibilidade dos Solos do Estado de São Paulo. Anais da E.S.A. "Luiz de Queiroz". Piracicaba, 31: 333-350。

FROST, R.E., 1960. Photointerpretation of Soil. In: AMERICAN SOCIETY OF PHOTOGRAMMETRY. Manual of Photographic Interpretation. Washington, p. 343-402.

GEVAERD, I., 1974. Parâmetros Fotoanalíticos de Três Unidades de Solo: da Região Nordeste Paranaense. Piracicaba, ESALQ/USP, 110 p. [Dissertação de Mestrado].

GOOSEN, D., 1967. Aerial Photo Interpretation in Soil Survey. Food and Agriculture Organization of The United Na tion, Roma, 55 p. [Soil Bulletin n. 6].

GUIMARAES, M.F., 1984. Evolução do Relevo e do Padrão de Drenagem em Solos Provenientes de Rochas Eruptivas Băsi cas. Piracicaba, ESALQ/USP, 102 p. [Dissertação de Mes trado]。

HORTON, R.E., 1945. Erosional Development of Streams and Their Drainage Basins: Hydrophysical Approach to Quanti tative Morphology。 Bul. Geol. Soc. Amer., 56: 275-370. 
INSTITUTO BRASILEIRO DE GEOGRAFIA E ESTATISTICA,, 1974. Folha Topogräfi ca de Pariqüera-Açu. Superintendência de Cartografia, São Paulo. Escala 1:50.000

LEĀO, S.R.F., 1973. Interpretação Fotogräfica dos Padrões de Drenagem Desenvolvidos em Dois Solos do Distrito Federal. Piracicaba, ESALQ/ USP, 110 p. [Dissertação de Mestrado].

LEÃO, S.R.F., 1983. Interpretação Fotogräfica de Características do Relevo e da Rede de Drenagem em Dois Solos do Distrito Federal. Piracicaba, ESALQ/USP, 166 p. [Tese de Doutoramento].

LEPSCH, I.F., 1985. O Inventário de Solos como Base ao Planejamento Racional do Uso da Terra. ' In: FUNDACAOA CARGILL (Ed.). ' Aspectos de Manejo do Solo. Campinas, p. 1-42.

LUEDER, D.R., 1959. 'Aerial Photographic Interpretation: ' ' Principles and Applications. New York, McGraw-Hill Ed., 462 p.

MANECHINI , C., 1981. Utilização de Fotografias Aêreas na Comparação de Sistemas de Amostragem e Estudo das Redes de Drenagem de Três Solos da Região de Tambaü - SP. Piracicaba, ESALQ/USP, 133 p. [Dis sertação de Mestrado] .

MARCHETTI, D.A.B., 1969. Fotointerpretação de Atributos de Relevo Aplicada a Solos da Região de Piracicaba.Piracicaba, ESALQ/USP, 58 p. [Tese de Doutoramento].

MELFI, A.J.; I. BITTENCOURT e U.G. CORDANI, 1965. Reconhecimento Foto geolögico de Parte do Grupo Açungui. Bragantia. Campinas, 24: 447_ -474 . 
MILLER, V.C. e C.F. MILLER, 1961。 Photogeology. New York, McGraw-Hill Ed., 248 p.

MORGENTAL, A. e F. BATOLLA JR., 1974. Mapa Geológico. In: PROJETO SUDELPA, Relatōrio Final - Geologia. Folha Pari qüera-Açu. São Paulo, Companhia de Pesquisas de Recursos Minerais (Escala 1:50.000). Vol. III - Anexo III Parte II.

MORGENTAL, A.; F. BATOLLA JR.; G.G. PINTO; I.P. PAIVA e J. B.C. DRUMOND, 1975. Relatório Final - Geologia. PROJETO SUDELPA. São Paulo, Companhia de Pesquisas de Recursos Minerais. Vol. I, $707 \mathrm{p}$.

NOGUEIRA, F.P., 1979. Utilização de Fotografias Aêreas em Trēs Escalas no Estudo de Redes de Drenagem em Diferentes Unidades de Solo. Piracicaba, ESALQ/USP, 110 p.[Dis sertação de Mestrado].

PARVIS, M., 1950. Drainage Pattern Significance in Airpho to Identification of Soils and Bedrocks. Photogram.Eng. Washington, $16(3): 387-408$ 。

PFEIFER, R.M., 1984. Fotointerpretação de Bacias Hidrogrāa ficas e Amostras Circulares de Redes de Drenagem dos So los do Parque Estadual da Ilha do Cardoso (SP). Piraci caba, ESALQ/USP, 90 p. [Dissertação de Mestrado].

POLITANO, W., 1980. Estudo Fotointerpretativo Sobre a Mor fometria das Areas de Dois Solos Podzólicos Vermelho-Amarelos. Piracicaba, ESALO/USP, 169 p. [Tese de Doutoramento]。 
PRESSINOTTI, P.C. e M.M.N. PRESSINOTTI, 1980. Contribuição à Geologia dos Arredores de Registro, SP. Rev. IG. São Paulo, 1 (2): 5-24。

RABBEN, E.L., 1960. Fundamentals of Photo-Interpretation. In: AMERICAN SOCIETY OF PHOTOGRAMMETRY. Manual of Photographic Interpretation. Washington, p. 99-186.

RAMALHO, R., 1974. Mapa Geomorfológico. In: PROJETO SUDEL PA, Relatório Final - Geomorfologia. Folha Pariquiera-Açu. São Paulo, Companhia de Pesquisas de Recursos Minerais (Escala 1:50.000). Vol. XIV - Anexo VIII - Parte I I.

RAMALHO, R. e J.E.P. HAUSEN, 1975. Relatörio Final - Geomorfologia. PROJETo SUDELPA. Säo Paulo, Companhia de Pes quisas de Recursos Minerais. Vol。XII, 105 p。

RAY, R.G. e W.A. FISCHER, 1960. Quantitative Photography: A Geologic Research Tool. Photogram. Eng. Washington, 26 (1): 143-150.

RICCI, M. e S. PETRI, 1965. Princípios de Aerofotogrametria e Interpretação Geológica. São Paulo, Ed. Nacional, São Paulo, Ed. Nacional, 226 p.

ROURKE, J.D. e M.E. AUSTIN, 1951. The Use of Airphotos for Soil Classification and Mapping in the Field. Photogram. Eng. Washington, 17: 738-741. 
SAKAI, E.; I.F. LEPSCH e A.Z. AMARAL, 1983. Carta de Solos da Folha $24^{\circ} 15^{\prime}-24^{\circ} 45^{\prime}$ 's e $47^{\circ} 30^{\prime}-48^{\circ} 00^{\prime}$ W (Registro, Juquiä, Pariquiera-Açu e Iguape). Levantamento Pe dológico de Reconhecimento - Semidetalhado da Região do Rio Ribeira do Iguape no Estado de São Paulo. Secret.de Agric. e Abast. do Est. de São Paulo; Coord. da Pesq. Agropec.; Inst. Ağron., Seção de Pedologia e Est. Exp. de Pariqüera-Açu. Escala 1:100.000

SAKAI, E. e I.F. LEPSCH, 1984. Levantamento Pedológico De talhado da Estação Experimental de Pariqüera-Açu, SP. B. Técn. Inst. Agron. Campinas, 83 p.

SILVA, L.C.F., 1977. Fotointerpretaçāo de Redes de Drenagem de Dois Solos do Municĩpio de São Pedro (SP). Piracicaba, ESALQ/USP, 114 p. [Dissertação de Mestrado].

SIMONSON, R.W., 1950. Use of Aerial Photographs in Soil Surveys. Photogram. Eng. Washington, 16: 308-315.

SMITH, K.G., 1950. Standards for Grading Texture of Erosional Topography. Amer. J. Sci., 248: 655-668。

SMITH, G.D. e H.R. AANDAHL, 1957. Soil Classification and Surveys. In: UNITED STATE DEPARTMENT OF AGRICULTURE. Soil. Washington, p. 396-400。

SOIL SURVEY STAFF, 1951。 Soil Survey Manual。United States Department of Agriculture. Washington. 503 p. (Handbook 18 ). 
SOUZA, M.L.P., 1975. Fotointerpretação de Redes de Drenagem de Três Solos com Horizonte B Latossólico Ocorrentes no Município de Ponta Grossa - PR. Piracicaba,ESALQ/ USP, 135 p. [Dissertação de Mestrado].

STRAHLER, A.N., 1952. Hypsometric (Area-Altitude) Analysis of Erosional Topography. Bull. Geol. Soc. Amer. Colorado, 63: 1117-1142.

STRAHLER, A.N., 1957. Ouantitative Analysis of Watershed Geomorphology. Trans. Am. Geophys. Un. New Haven, 38: 913-920。

SUGUIO, K. e J.J. BIGARELlA, 1979. Ambientes de Sedimentação: sua Interpretação e Importância - Ambiente Fluvial. Ed. da Univ. Fed. do Paraná, Associação de Defesa e Edu cação Ambiental, Curitiba, 183 p.

SUMMERSON, C.H., 1954. A Philosophy for Photointerpreters. Photogram. Eng. Washington, 20: 396-397.

TIE-BI-YOUAN, M., 1980. Sols Ferrallitiques de La Valëe du Ribeira de Iguape (SP) - Caracterisation et Problemes de Classification. Inst. de Geociēncias (USP), São PauloInst. Agronômico de Campinas (IAC), Campinas, 85 p. [Re latório de Estágio].

TIE-BI-YOUAN, M.; E. SAKAI; I.F. LEPSCH e A. CHAUVEL, 1983. Caracterizaçāo e Classificação de Solos da Formaçāo Pariqüera-Açu (SP) . Rev. bras. Ci. Solo. Campinas, 7: 183190 。 
VALERIO FILHO, M.; J.C.N. EPIPHANIO e A.R. FORMAGGIO, 1981. Metodologia de Interpretaçāo de Dados de Sensoriamento Remoto e Aplicações em Pedologia. São José dos Campos, INPE, $51 \mathrm{p}$. [INPE-2211-MD/008] .

VASQUES FILHO, J., 1972. Critérios Morfométricos Aplicados $\vec{a}$ Fotointerpretação de Redes de Drenagem em Três Unidades de Solo no Município de Piracicaba (SP). Piracicaba, ESALQ/USP, 113 p. [Tese de Doutoramento] . 
141 .

A P E N D I C E 
142.

Neste Apêndice estão inseridas, através das Figuras 1 a 6 , as representaçōes grāficas das bacias de ter ceira ordem de ramificação de cada unidade de solo em estú do neste trabalho que, atravês do processo utilizado de se leção de amostras representativas, foram descartadas.

As Tabelas 1 a 5 contêm os valores dos parâa metros utilizados na seleção das amostras para cada unidade de solo, para as bacias representadas nas figuras 1 a 6 . 

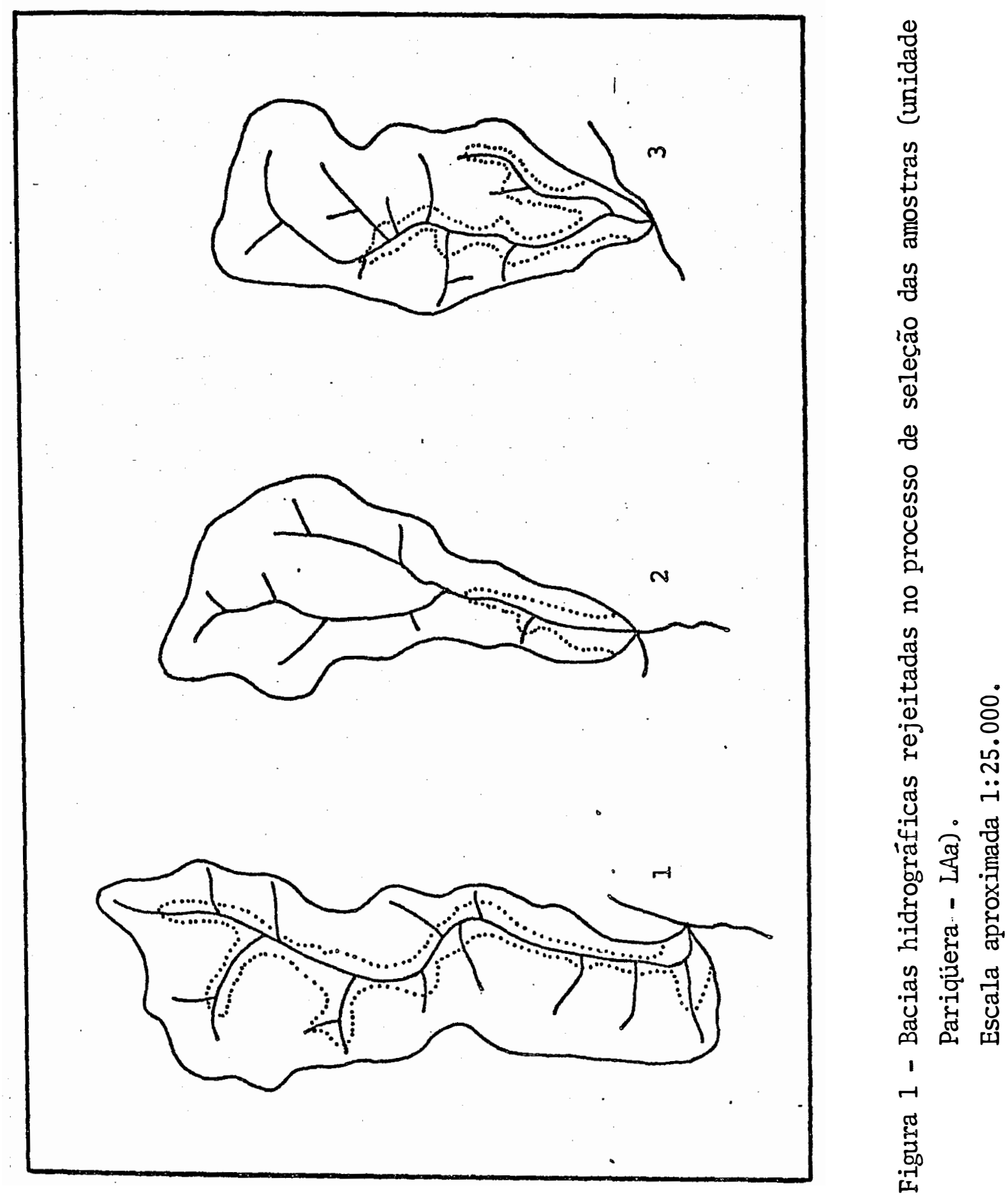

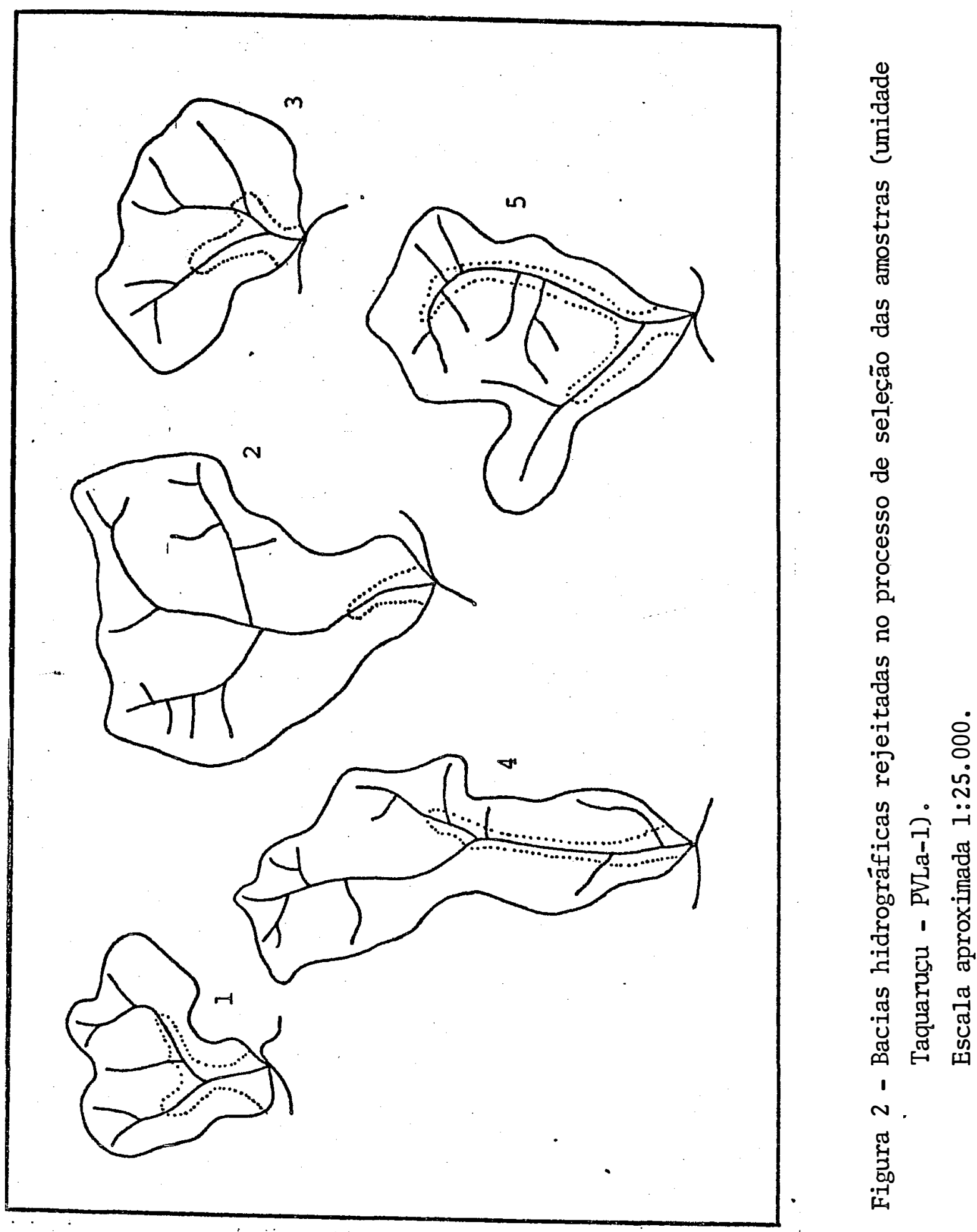
145.
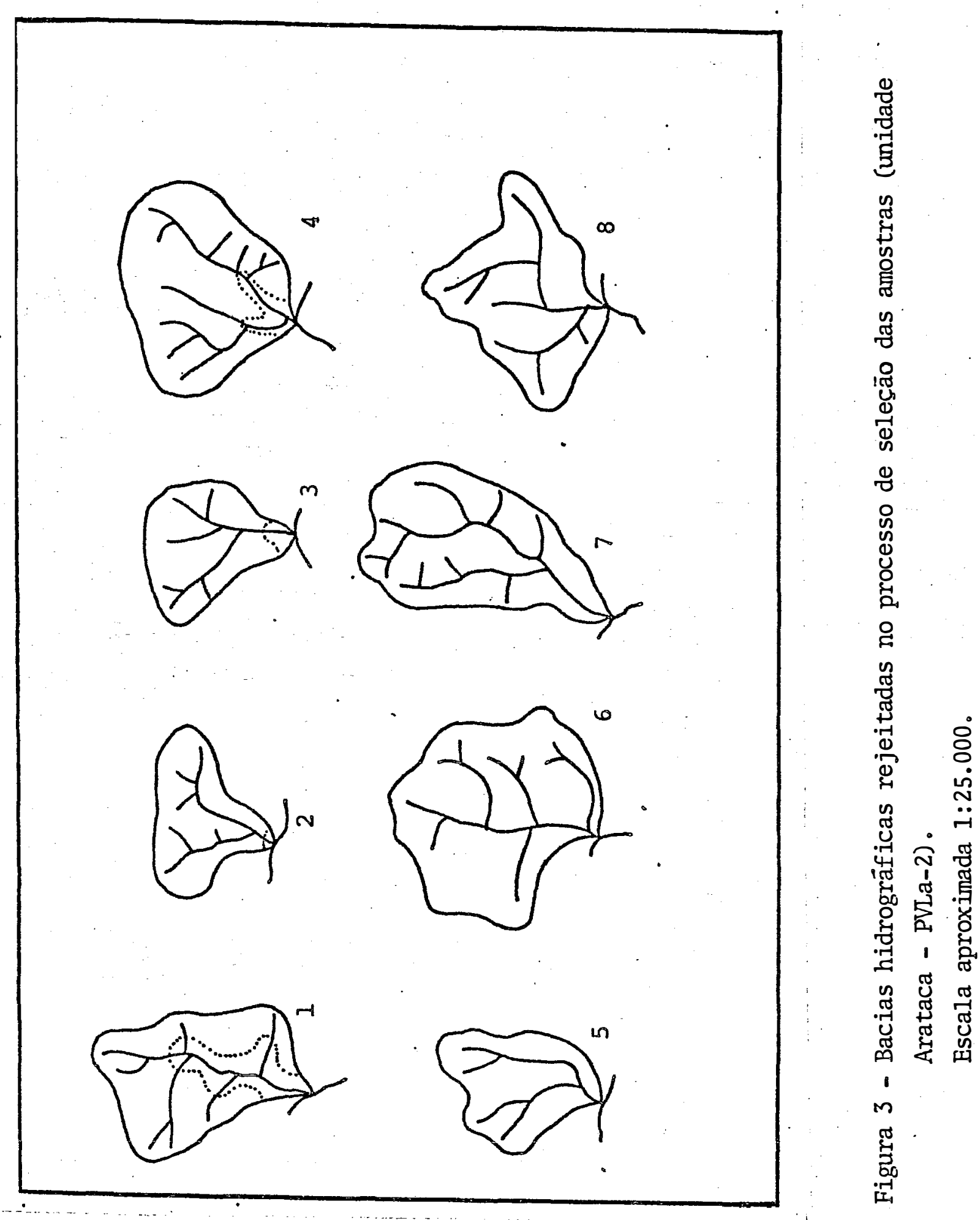

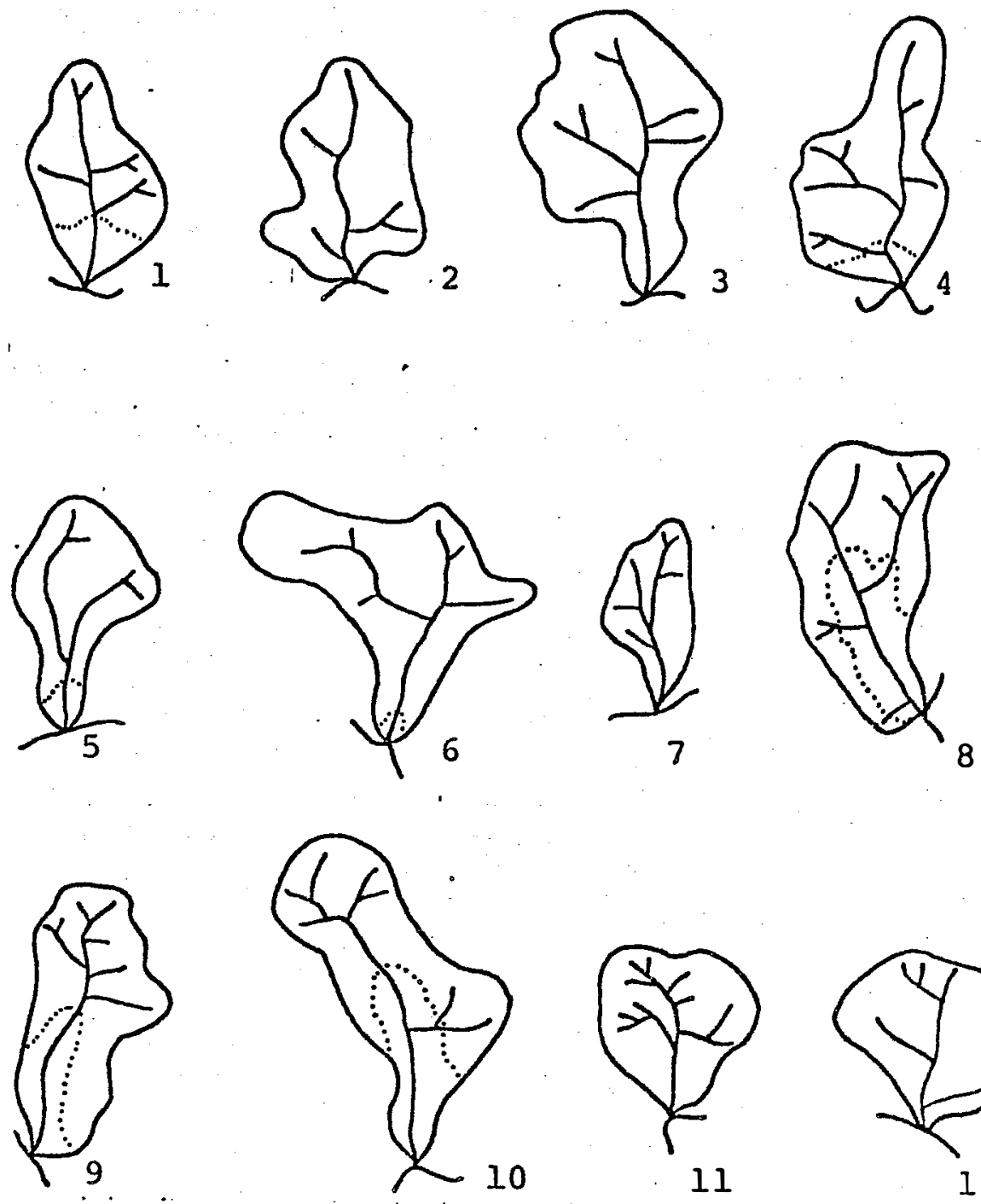

11

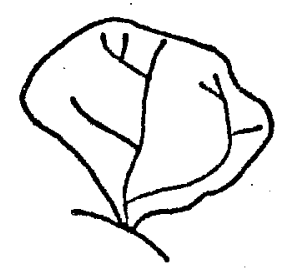

12
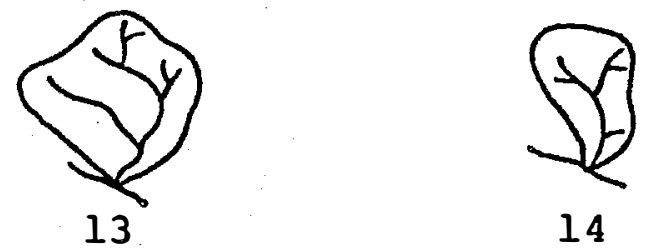

Figura 4 - Bacias hidrogräficas rejeitadas no processo de seleção das amostras (unidade Vapamirim - PVa)。

Escala aproximada 1:25.000。 

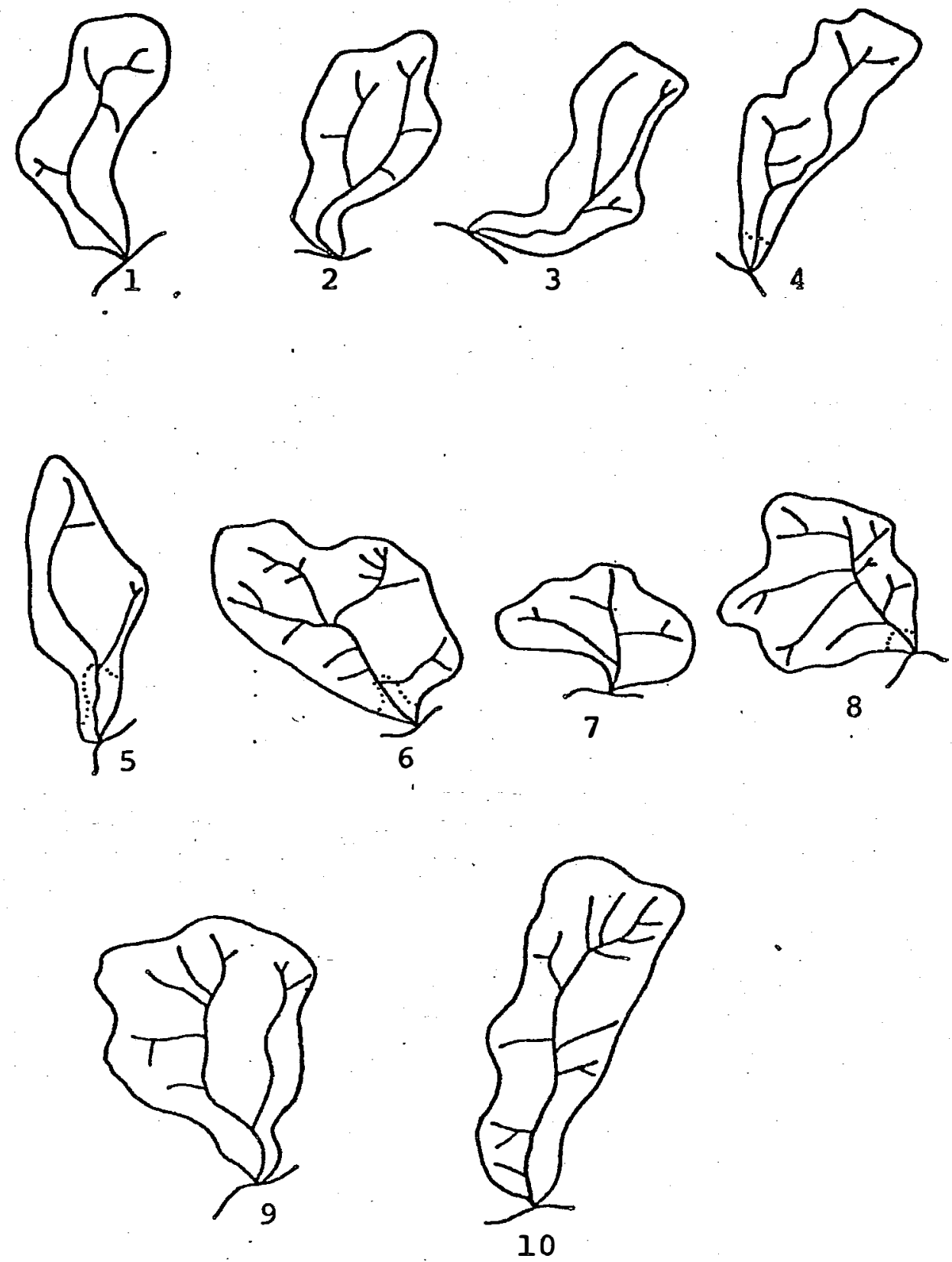

Figura 5 - Bacias hidrogräficas rejeitadas no processo de seleçāo das amostras (unidade Canfilito - $\mathrm{Ca}-2$ )。

Escala aproximada 1:25.000。 


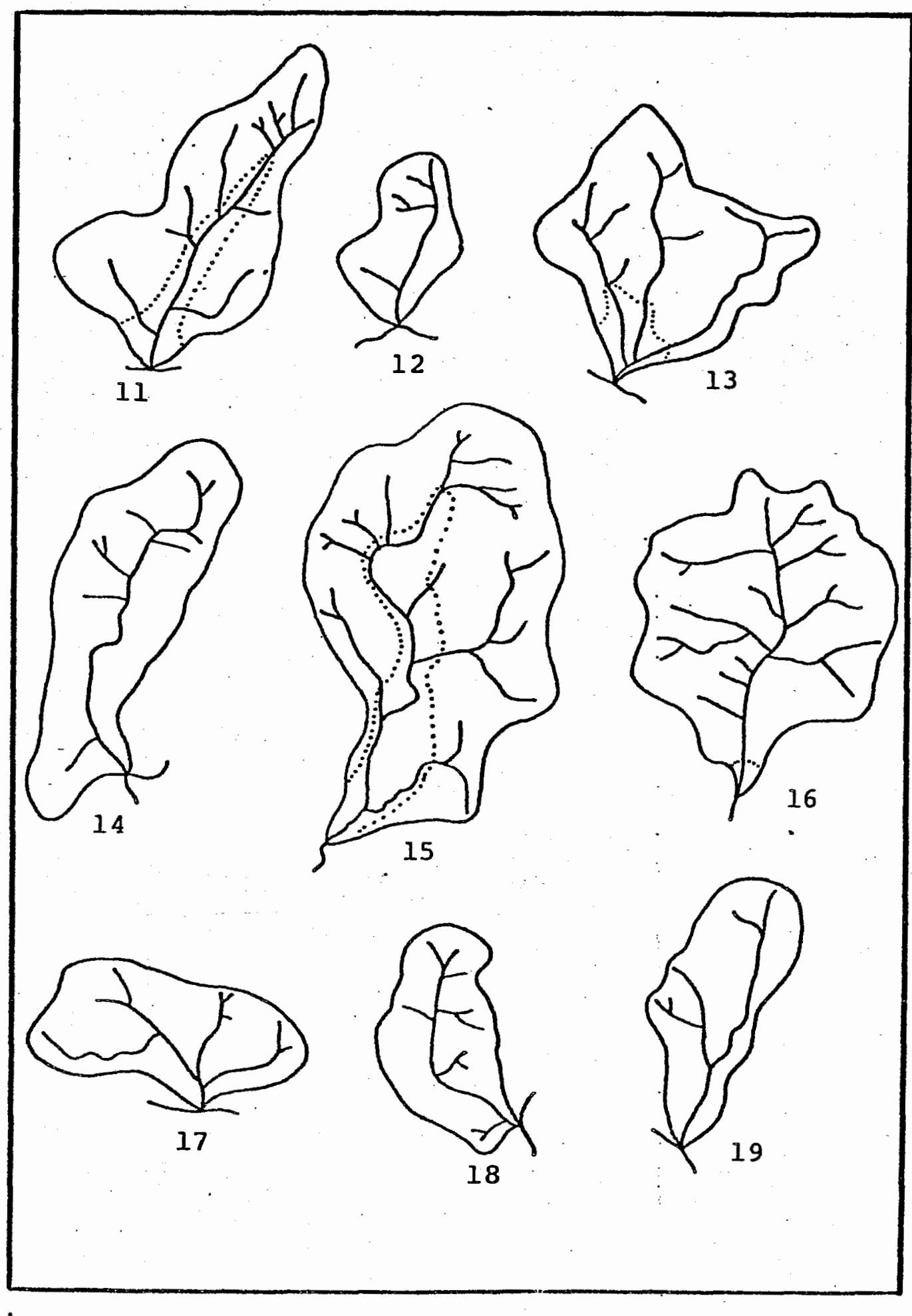

Figura 6 - Bacias hidrogräficas rejeitadas no processo de seleção das amostras (unidade Canfilito - $\mathrm{Ca}-2$ ).

Escala aproximada $1: 25.000$. 
Tabela 1 - Valores dos parâmetros utilizados no processo de seleção das amostras, para bacias descartadas ocorrentes na unidade Pariqüera (LAa).

\begin{tabular}{|c|c|c|c|c|c|c|c|c|}
\hline \multirow{2}{*}{$\begin{array}{c}\text { BACIA } \\
\text { No }\end{array}$} & \multicolumn{8}{|c|}{ P A R A ME TROS } \\
\hline & $\begin{array}{c}\mathrm{MC} \\
(\mathrm{km})\end{array}$ & $\begin{array}{c}\mathrm{ML} \\
(\mathrm{km})\end{array}$ & $\underset{(\mathrm{km})}{\mathrm{P}}$ & $\begin{array}{l}\text { CRP } \\
(\mathrm{km})\end{array}$ & $\begin{array}{l}\text { CTR } \\
(\mathrm{km})\end{array}$ & $\underset{\left(\mathrm{lom}^{2}\right)}{\mathrm{A}}$ & Nw1 & $\begin{array}{l}\text { Lw1 } \\
\text { (km) }\end{array}$ \\
\hline 1 & 2,234 & 0,857 & 5,975 & 2,500 & 5,425 & 1,372 & 14 & 2,775 \\
\hline 2 & 1,807 & 0,841 & 4,475 & 1,475 & 3,225 & 0,844 & 9 & 1,050 \\
\hline 3 & 1,661 & 0,757 & 4,225 & 1,800 & 4,175 & 0,909 & 12 & 2,000 \\
\hline
\end{tabular}

Tabela 2 - Valores dos parâmetros utilizados no processo de seleção das amostras, para bacias descartadas ocorrentes na unidade Taquaruçu (PVLa-1).

\begin{tabular}{cccccccccc}
\hline \multirow{8}{*}{$\begin{array}{c}\text { BACIA } \\
\text { No }\end{array}$} & $\begin{array}{c}\text { MC } \\
(\mathrm{km})\end{array}$ & $\begin{array}{c}\text { M } \\
(\mathrm{km})\end{array}$ & $\begin{array}{c}\mathrm{P} \\
(\mathrm{km})\end{array}$ & $\begin{array}{c}\text { CRP } \\
(\mathrm{km})\end{array}$ & $\begin{array}{c}\text { CTR } \\
(\mathrm{km})\end{array}$ & $\begin{array}{c}\mathrm{A} \\
\left(\mathrm{km} \mathbf{2}^{2}\right)\end{array}$ & $\begin{array}{c}\text { Nw1 } \\
(\mathrm{km})\end{array}$ \\
\hline 1 & 0,797 & 0,875 & 2,825 & 0,887 & 2,112 & 0,409 & 6 & 0,950 \\
2 & 1,458 & 1,167 & 4,375 & 1,600 & 4,312 & 1,072 & 12 & 1,550 \\
3 & 0,834 & 1,090 & 3,000 & 0,775 & 2,337 & 0,562 & 6 & 1,375 \\
4 & 1,797 & 0,745 & 4,500 & 1,787 & 4,262 & 0,816 & 12 & 2,000 \\
5 & 1,268 & 1,110 & 4,000 & 1,400 & 4,025 & 0,759 & 10 & 2,175 \\
\hline
\end{tabular}


Tabela 3 - Valores dos parâmetros utilizados no processo de seleção das amostras, para as bacias descartadas ocorrentes na unidade Arataca (PVLa-2).

\begin{tabular}{ccccccccc}
\hline \multirow{2}{*}{$\begin{array}{c}\text { BAC IA } \\
\text { No }\end{array}$} & $\begin{array}{c}\text { MC } \\
(\mathrm{km})\end{array}$ & $\begin{array}{c}\text { ML } \\
(\mathrm{km})\end{array}$ & $\begin{array}{c}\text { P } \\
(\mathrm{km})\end{array}$ & $\begin{array}{c}\text { CRP } \\
(\mathrm{km})\end{array}$ & $\begin{array}{c}\text { C TR } \\
(\mathrm{km})\end{array}$ & $\begin{array}{c}\text { A } \\
\left(\mathrm{km}^{2}\right)\end{array}$ & Nw1 & $\begin{array}{c}\text { Lw1 } \\
(\mathrm{km})\end{array}$ \\
\hline 1 & 0,890 & 0,616 & 2,450 & 0,800 & 1,975 & 0,337 & 7 & 1,000 \\
2 & 0,578 & 0,478 & 1,875 & 0,512 & 1,250 & 0,206 & 6 & 0,500 \\
3 & 0,606 & 0,562 & 1,775 & 0,475 & 1,275 & 0,237 & 6 & 0,700 \\
4 & 0,787 & 0,722 & 2,400 & 0,750 & 2,525 & 0,412 & 10 & 1,475 \\
5 & 0,678 & 0,505 & 1,812 & 0,650 & 1,400 & 0,212 & 4 & 0,625 \\
6 & 0,842 & 0,900 & 2,750 & 0,750 & 2,500 & 0,481 & 9 & 1,025 \\
7 & 1,060 & 0,602 & 2,700 & 1,025 & 2,775 & 0,400 & 10 & 1,250 \\
8 & 0,722 & 0,772 & 2,550 & 0,375 & 2,025 & 0,344 & 7 & 1,200 \\
\hline
\end{tabular}

Tabela 4 - Valores dos parâmetros utilizado no processo de seleção das amostras, para as bacias descartadas ocorrentes na unidade Vapamirim (PVa).

\begin{tabular}{|c|c|c|c|c|c|c|c|c|}
\hline \multirow{2}{*}{$\begin{array}{c}\text { BAC IA } \\
\text { 우 }\end{array}$} & \multicolumn{8}{|c|}{$P A R \widehat{A} M E T R O S$} \\
\hline & $\begin{array}{c}\mathrm{MC} \\
(\mathrm{km})\end{array}$ & $\begin{array}{c}\mathrm{ML} \\
(\mathrm{km})\end{array}$ & $\underset{(\mathrm{km})}{\mathrm{P}}$ & $\begin{array}{l}\text { C RP } \\
(\mathrm{km})\end{array}$ & $\begin{array}{l}\text { C TR } \\
(\mathrm{km})\end{array}$ & $\underset{\left(\mathrm{km}^{2}\right)}{\mathrm{A}}$ & Nw1 & $\begin{array}{l}\text { Lw1 } \\
(\mathrm{km})\end{array}$ \\
\hline 1 & 0,671 & 0,368 & 1,562 & 0,550 & 1,062 & 0,181 & 7 & 0,475 \\
\hline 2 & 0,644 & 0,460 & 1,800 & 0,587 & 1,087 & 0,175 & 5 & 0,575 \\
\hline 3 & 0,841 & 0,559 & 2,262 & 0,750 & 1,700 & 0,294 & 7 & 0,800 \\
\hline 4 & 0,783 & 0,450 & 2,012 & 0,737 & 1,550 & 0,231 & 8 & 0,750 \\
\hline 5 & 0,692 & 0,425 & 1,750 & 0,675 & 1,125 & 0,162 & 4 & 0,175 \\
\hline 6 & 0,711 & 0,860 & 2,525 & 0,700 & 1,462 & 0,269 & 6 & 0,625 \\
\hline 7 & 0,542 & 0,273 & 1,250 & 0,512 & 0,975 & 0,100 & 6 & 0,500 \\
\hline 8 & 0,812 & 0,400 & 2,250 & 0,712 & 1,712 & 0,250 & 8 & 0,775 \\
\hline 9 & 0,800 & 0,407 & 2,037 & 0,762 & 1,312 & 0,219 & 7 & 0,550 \\
\hline 10 & 0,989 & 0,448 & 2,500 & 0,975 & 1,737 & 0,272 & 7 & 0,800 \\
\hline 11 & 0,507 & 0,459 & 1,500 & 0,500 & 1,312 & 0,156 & 10 & 0,725 \\
\hline 12 & 0,517 & 0,602 & 1,700 & 0,500 & 1,500 & $0 ; 187$ & 7 & 0,650 \\
\hline 13 & 0,443 & 0,435 & 1,250 & 0,475 & 1,000 & 0,125 & 6 & 0,525 \\
\hline 14 & 0,364 & 0,231 & 0,975 & 0,262 & 0,487 & 0,062 & 5 & 0,275 \\
\hline
\end{tabular}


Tabela 5 - Valores dos parâmetros utilizados no processo de seleção das amostras, para as bacias descartadas ocorrentes na unidade Canfilito $(\mathrm{Ca}-2)$.

\begin{tabular}{|c|c|c|c|c|c|c|c|c|}
\hline \multirow{2}{*}{$\begin{array}{c}\text { BACIA } \\
\text { № }\end{array}$} & \multicolumn{8}{|c|}{$P A R \widehat{A} M E R O S$} \\
\hline & $\begin{array}{c}\mathrm{MC} \\
(\mathrm{km})\end{array}$ & $\begin{array}{c}\mathrm{ML} \\
(\mathrm{km})\end{array}$ & $\begin{array}{c}P \\
(\mathrm{~km})\end{array}$ & $\begin{array}{l}\text { CRP } \\
(\mathrm{km})\end{array}$ & $\begin{array}{l}\text { CTR } \\
(\mathrm{km})\end{array}$ & $\begin{array}{c}\mathrm{A} \\
\left(\mathrm{km}^{2}\right)\end{array}$ & Nw1 & $\begin{array}{l}\text { Lw1 } \\
(\mathrm{km})\end{array}$ \\
\hline 1 & 0,795 & 0,314 & 2,025 & 0,762 & 1,237 & 0,225 & 6 & 0,300 \\
\hline 2 & 0,772 & 0,428 & 1,987 & 0,762 & 1,500 & 0,206 & 7 & 0,400 \\
\hline 3 & 0,827 & 0,389 & 2,212 & 0,875 & 1,575 & 0,187 & 5 & 0,500 \\
\hline 4 & 0,931 & 0,311 & 2,250 & 0,937 & 1,650 & 0,217 & 6 & 0,500 \\
\hline 5 & 0,938 & 0,364 & 2,037 & 0,925 & 1,287 & 0,206 & 4 & 0,250 \\
\hline 6 & 0,887 & 0,530 & 2,362 & 0,787 & 2,500 & 0,325 & 16 & 0,950 \\
\hline 7 & 0,418 & 0,596 & 1,650 & 0,425 & 1,162 & 0,154 & 6 & 0,400 \\
\hline 8 & 0,675 & 0,579 & 2,025 & 0,700 & 2,237 & 0,242 & 14 & 0,800 \\
\hline 9 & 0,875 & 0,700 & 2,537 & 0,850 & 2,375 & 0,400 & 10 & 0,775 \\
\hline 10 & 1,152 & 0,451 & 2,775 & 1,112 & 2,675 & 0,369 & 15 & 1,325 \\
\hline 11 & 1,335 & 0,722 & 3,450 & 1,250 & 3,187 & 0,556 & 12 & 1,750 \\
\hline 12 & 0,651 & 0,378 & 1,687 & 0,575 & 1,062 & 0,171 & 5 & 0,475 \\
\hline 13 & 1,044 & 1,038 & 3,250 & 0,937 . & 3,262 & 0,550 & 9 & 1,075 \\
\hline 14 & 1,274 & 0,508 & 3,525 & 1,312 & 2,250 & 0,533 & 9 & 0,775 \\
\hline 15 & 1,732 & 1,009 . & 4,512 & 1,987 & 6,125 & 1,081 & 20 & 2,250 \\
\hline 16 & 1,218 & 0,965 & 3,625 & 1,175 & 4,687 & 0,756 & 18 & 2,000 \\
\hline 17 & 0,733 & 0,520 & 2,512 & 0,625 & 2,125 & 0,366 & 8 & 0,975 \\
\hline 18 & 0,789 & 0,458 & 2,175 & 0,825 & 1,712 & 0,285 & 10 & 0,525 \\
\hline 19 & 1,051 & 0,420 & 2,487 & 1,025 & 1,775 & 0,308 & 5 & 0,700 \\
\hline
\end{tabular}

